\title{
Rizómata: \\ Uma introdução às raízes da música de Iannis Xenakis
}

Dissertação apresentada ao Programa de Pós-Graduação em Artes, Área de Concentração Musicologia, Linha de Pesquisa História Estrutura e Estilo na Música, da Escola de Comunicações e Artes da Universidade de São Paulo, como exigência parcial para obtenção do Título de Mestre em Artes, sob a orientação do Prof. Dr. Fernando Henrique de Oliveira Iazzetta.

\section{São Paulo \\ 2006}




\section{Rizómata: \\ Uma introdução às raízes da música de Iannis Xenakis}

Dissertação apresentada ao Programa de Pós-Graduação em Artes, Área de Concentração Musicologia, Linha de Pesquisa História Estrutura e Estilo na Música, da Escola de Comunicações e Artes da Universidade de São Paulo, como exigência parcial para obtenção do Título de Mestre em Artes, sob a orientação do Prof. Dr. Fernando Henrique de Oliveira Iazzetta.

\section{São Paulo \\ 2006}


Rizómata:

Uma introdução às raízes da música de Iannis Xenakis 
Para Samira 


\section{AGRADECIMENTOS}

Agradeço meus pais e irmãos pela compreensão e, principalmente, pelo necessário.

Agradeço meu orientador, Prof. Dr. Fernando Henrique de Oliveira Iazzetta, pelo inestimável auxílio prestado. 


\section{RESUMO}

Os fundamentos físicos e matemáticos utilizados em criação musical pelo compositor grego Iannis Xenakis são o objeto de investigação desta dissertação. A compreensão de sua teoria musical é essencial para assimilação de sua obra. O período abrangido corresponde a meados da década de 1950 ao início da década de 1960. Abordamos o surgimento da música estocástica, seus desdobramentos e música simbólica desenvolvido pelo compositor. 


\begin{abstract}
The physical and mathematical basis used in musical creation by greek composer Iannis Xenakis are the object of investigation from this thesis. The comprehension of his musical theory is essential to assimilate his work. The period covered correspond to middle of 1950 decade up to beggining of 1960 decade. We aproach the arise of stochastic music, his extensions and symbolic music developed by composer.
\end{abstract}




\section{SUMÁRIO}

1 Introdução - ․ㅡㄹ 1

1.1 Dados Bigráficos ……....... 3

1.2 Preâmbulos Filosóficos ㄴ..ㄴ.. 5

1.2.1 Algumas Considerações Sobre Lógica - $\quad 10$

1.3 Fundamentos Físicos e Matemáticos $\quad 3 \quad 11$

1.3.1 Teoria da Probabilidade …ㄴ.......... 14

1.3.2 Lei dos Grandes Números …됴 $\quad 15$

1.3.3 Lei de Poisson …눈 16

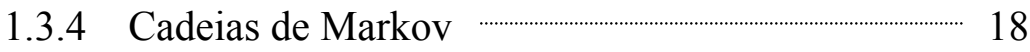

1.3.5 Teoria Cinética dos Gases ……___... 19

1.3.6 Teoria dos Conjuntos …

1.3.7 Sinais de Gabor … - $\begin{array}{ll}\text { 1. } & 27\end{array}$

1.4 Música Estocástica e Acaso na Música do Séc XX ․․ - 28

1.5 Música e Desenho Arquitetônico ㄱ..ㄴ $\quad 29$

2 Música Estocástica $\longrightarrow 32$

2.1 Anasteria -32

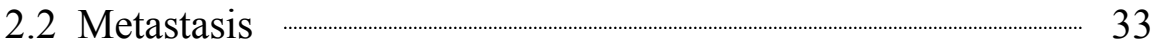

2.3 Pithoprakta …… 39

2.4 Acerca da Linguagem -.. $\quad 44$

2.5 Achorripsis ——— $\quad 46$

2.6 As Peças ST ……

2.7 A Música Estocástica:Perspectiva Perceptiva - ㄱa $\quad 56$

3 Música Estocástica Markoviana …는 60

3.1 A Música Concreta de Xenakis …… 60

3.2 Música Estocástica Markoviana …_. 61

3.2.1 Teoria de Gabor ㄴ $\quad 62$

3.2.2 Cadeias de Markov …두은 63

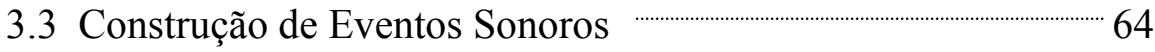

3.3.1 Operações com os Eventos Sonoros ou Telas ……... 67

3.3.2 Ligação dos Eventos Sonoros numa Composição - -...70

3.4 Analogique A …… 72

3.5 Analogique B …

3.6 Analogique A+B $\quad$.

4 Música Simbólica - $\quad 79$

4.1 A Simbolização da Música …﹎.. _ _ _ 80

4.2 A Linguagem Musical Formal ……

4.2.1 Elemento: Caso Sonoro Geral 눈 $\quad 82$

4.2.2 Um Novo Conceito de Nota …… $\ldots$

4.2.3 Vetor Sonoro - ——_—_ 88

4.2.4 Espaço Vetor Associado a Uma Grandeza Escalar 90

4.2.5 Valoração numérica de um Espaço Vetor Sonoro 90 
4.2.6 Multiplicidade Vetorial Linear ……………………………………………....... 91

4.2.7 Duração e Unidade de Tempo $\quad 93$

4.2.8 Estrutura Temporal $\quad 94$

4.2.9 Estruturas no Tempo: Uma Extensão da Linguagem …ㅊ........96

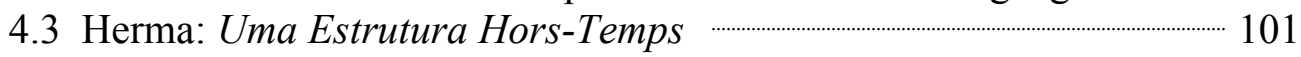

4.3.1 A Linguagem Musical Formal Aplicada a Herma ……………... 101

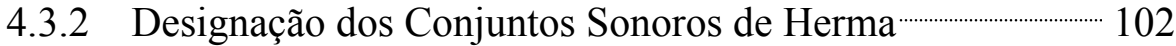

4.3.3 A Arquitetura Global de Herma ………………………… 103

4.3.4 Transcrição e Gravação ……………………………………………………...106

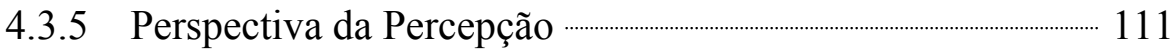

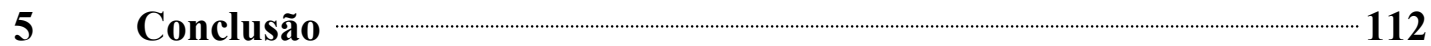

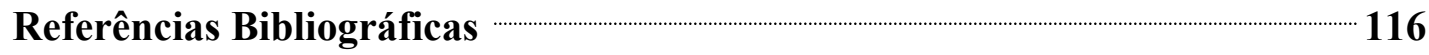

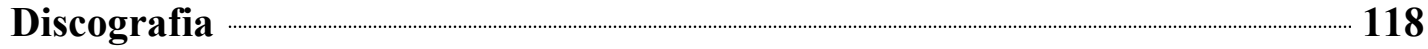




\section{INTRODUÇÃo}

Os fundamentos físicos e matemáticos utilizados em criação musical por Iannis Xenakis são o objeto de investigação desta dissertação. A compreensão de sua teoria musical é essencial para assimilação de sua obra. O período abrangido corresponde a meados da década de 1950 ao início da década de 1960. Abordaremos o surgimento da música estocástica, seus desdobramentos e música simbólica desenvolvidas pelo compositor. Dialogando com outras correntes estéticas proeminentes do pós-guerra especialmente o serialismo integral - Xenakis tomou rumos distintos, sem constituir movimento ou corrente estética, mas sim como teórico da música insurgente, e não menos influente. O termo grego que dá nome a essa dissertação - Rizómata - plural de raízes ou, em sentido figurado, fundamento ou elemento de todas as coisas, faz jus às origens de Xenakis e à nossa tentativa em elucidar as próprias raízes de sua estética. A presente dissertação é deste modo uma introdução ao pensamento e práxis musical do compositor grego.

Xenakis pretendia atingir um alto grau de abstração em suas composições, o principais problemas eram: Como lidar com mudanças de grandes massas de eventos sonoros? Como passar de um estado contínuo para um descontínuo e vice-versa? O compositor encontra as respostas para seus problemas composicionais na teoria matemática das probabilidades. Iniciando com Metastasis(1954), com fortes traços seriais, Xenakis compôs para orquestra de cordas uma peça onde os glissandos exercem um papel fundamental na construção de um plano musical em que um estado sonoro se transforma em outro sem quebra de continuidade. O passo seguinte foi a composição de Pithropakta(1955), em que o compositor não lida apenas com massas contínuas de glissandos, mas com a transformação de pontos sonoros - pizzicatos - em massas, onde a preocupação com os aspectos formais é quase inteiramente relegada às probabilidades. A música estocástica inicia-se com Achorripsis(1956), cujos aspectos formais estão totalmente baseados na estocástica, objetivo almejado pelo compositor. Essas composições despendiam meses de cálculos e testes manuais, mas o compositor vislumbrava a possível utilização de computadores na confecção de peças estocásticas. Logo após concluir Achorripsis, Xenakis teve acesso a computadores $I B M$ em linguagem Fortran. As peças 
estocásticas passaram a ser automatizadas por meio do software $S T$, desenvolvido pelo próprio compositor junto a colaboradores.

O porquê do uso do cálculo de probabilidades em suas composições deve-se ao fato de que Xenakis lida com a matéria sonora de uma perspectiva que até então havia sido pouco explorada, o universo microsonoro. Entendemos como eventos microsonoros na música de Xenakis desde glissandos ou pizzicatos numa orquestra até as possibilidades num estúdio eletroacústico, como a captação de sons ou síntese sonora, da ordem de frações de segundos. Uma coleção de eventos microsonoros se transforma numa massa sonora susceptível de vários níveis de densificação, ordem, desordem, continuidade, descontinuidade, espacialização, etc. A organização formal dessas massas sonoras o leva ao campo das probabilidades matemáticas. As investigações empreendidas por Xenakis dialogavam intimamente com o desenvolvimento das ciências e tecnologias de sua época, como veremos adiante.

Outro aspecto presente em sua obra é a aplicação da Teoria dos Conjuntos em criação musical, elaborando conjuntos estocasticamente e formalizando os mesmos dentro de esquemas lógicos, realizando peças como Herma(1962), para piano solo.

Constituímos acima um panorama do objeto de nossa investigação, o período inicial de Iannis Xenakis, como compositor e teórico. Mas antes de concluirmos esta introdução convém ainda investigarmos outros aspectos do pensamento de Xenakis, sendo que alguns deles serão retomados posteriormente. Cabe dizer que não faremos uma exposição minuciosa, tomaremos como base o objeto de estudo desta dissertação. Também não pretendemos esgotar o assunto nos breves tópicos que seguem, apenas apontar as linhas de pensamento do compositor grego e como elas convergem em sua música. Investigaremos as raízes filosóficas presentes no pensamento composicional de Xenakis; sua contextualização física e matemática, juntamente com seus aspectos de ligação entre ciência, tecnologia e música; sua ligação com o design arquitetônico; o diálogo com as operações de acaso em John Cage e indeterminação em Pierre Boulez. Primeiramente abordaremos sucintamente os dados biográficos do compositor. 


\subsection{DADOS BIOGRÁFICOS}

Iannis Xenakis nasceu em Bräila, Romênia. A data correta é desconhecida, talvez tenha nascido em primeiro de junho, o ano pode ter sido 1921 ou 1922. Seus pais, Clearchos Xenakis e Photini Pavlou, eram gregos da diáspora. Sua mãe era uma boa pianista e deu a ele uma flauta quando ele ainda tinha cinco anos. Por volta dos dez anos, em 1932, Xenakis deixa a Romênia e vai para a Grécia. Seu pai o matriculara num colégio na ilha de Spetasai. Neste colégio, o compositor desenvolve afeição pela matemática, pelo grego, pela literatura estrangeira e inicia a descoberta da música. Em 1938, Xenakis deixa a ilha e vai para Atenas estudar numa escola preparatória, sua intenção era ingressar no Instituto Politécnico de Atenas. Este período é também o início de um envolvimento mais sério do compositor com a música, quando inicia aulas particulares de harmonia, contraponto e análise. Suas transcrições geométricas de peças de Bach são um prenúncio do que viria a realizar futuramente em criação musical.

O compositor ingressou no Instituto Politécnico de Atenas em 1940, mas a escola foi fechada no primeiro dia de aula, 28 de Outubro, quando então as tropas de Mussolini invadem a Grécia. O Instituto seria então reaberto e fechado constantemente. O período é marcado pela atuação de Xenakis como ativista político de esquerda quando vai para a prisão inúmeras vezes. No primeiro dia do ano de 1945, Xenakis é atingido por estilhaços de uma granada que o ferem gravemente, esmagando seu queixo e arrancando o olho esquerdo. Dado como morto, foi abandonado, mas é encontrado pelo seu pai que o leva para um hospital onde é submetido a muitas cirurgias. No mesmo ano, em março, Xenakis obtém alta do hospital e volta a atuar clandestinamente como ativista. Novamente, é diversas vezes encarcerado. Vivendo uma vida semi-clandestina e, apesar dos trágicos acontecimentos em 1946, Xenakis é aprovado nos exames finais do Instituto Politécnico. Em 1947, sua situação torna-se insustentável na Grécia. Após fugir de um campo de prisioneiros, seu pai consegue para ele um passaporte falso e parte para a Itália. Com a pretensão de ir para os EUA, cruza ilegalmente a fronteira para ir até Paris. Naquele momento sua volta para a Grécia é quase impossível pois é acusado de terrorismo político, jurado de morte e seu pai e irmão vão para a cadeia. Em dezembro daquele mesmo ano, através da recomendação de amigos, Xenakis é contratado como engenheiro e passa a 
trabalhar na equipe do arquiteto Le Corbusier, período que dura mais de dez anos, muito produtivo, em que ele realiza projetos não só de engenharia, mas também enveredando pela arquitetura.

Conjuntamente ao período despendido ao lado de Le Corbusier, Xenakis novamente procurou complementar sua educação musical, conturbada pelos anos vividos na Grécia. Mas sua busca foi frustrante até encontrar-se com Olivier Messiaen em 1951, e no ano de 1952, quando passa a freqüentar suas aulas pontualmente, e menos regularmente em 1953. Entre os anos de 1949 e 1952, Xenakis compõe um total de 24 peças para piano solo e voz, apenas recentemente catalogadas. O ponto culminante desse período inicia-se em 1953, quando Xenakis inicia a composição de sua trilogia inconclusa Anasteria, iniciando com Procession vers lês eaux claires e Le Sacrifice. Ao invés de concluir a trilogia, Xenakis compõe Metastasis no início de 1954. Dada sua abstração a peça acabou por destoar do projeto original de sua trilogia. Esta última composição é o início da exploração de novas trajetórias compositivas. O ano de 1954 é marcado também pelo ingresso de Xenakis no Group de Recherches de Musique Concréte de Pierre Schaeffer (mais tarde renomeado como Group de Recherches Musicales). Xenakis permaneceria no grupo até 1962. Suas peças concretas mais conhecidas são Concret Ph e Diamorphosis, ambas compostas no estúdio de música concreta coordenado por Schaeffer.

O período que vai de 1954 com a composição de Metastasis, até o ano de 1962, quando compõe a peça para piano Herma, constitui o cerne do desenvolvimento das teorias e aplicações da música de Xenakis. As décadas seguintes seriam então caracterizadas pelo aprofundamento dos fundamentos teóricos já desenvolvidos e pela busca de novos procedimentos formais, sem que isso significasse necessariamente uma cisão com suas raízes. Podemos destacar desse longo período produtivo a criação de espetáculos envolvendo design arquitetônico, luz e som, os chamados Polytopes; o aparato tecnológico denominado UPIC para criação de obras a partir de desenhos convertidos em material sonoro e até mesmo para composição musical, e por fim, na década de 1990, mais um feito de Xenakis foi o desenvolvimento de um software para a realização de síntese sonora baseada em procedimentos probabilísticos: o GENDY. Essa última realização retoma as 
premissas que levaram Xenakis a compor suas primeiras peças estocásticas, concluindo um projeto de formalização musical ao qual dedicou a maior parte de sua vida.

O compositor faleceu em 4 de fevereiro de 2001, na sua própria casa, devido ao agravamento do câncer que vinha sofrendo.

\subsection{PreÂMbulos Filosóficos}

As origens gregas de Xenakis, bem como sua formação acadêmica em território grego $^{1}$, foram determinantes em sua trajetória como compositor. Suas teorias musicais sempre dialogaram com as origens do pensamento ocidental, principalmente no período que concerne ao desenvolvimento de sua música estocástica. É no pensamento de Pitágoras de Samos (540-496 a.C.), Heráclito de Éfeso (570 a.C - 475 a.C), Parmênides de Eléia (540 a.C - 470 a.C), e Platão (c. 428-27 - c.348-47 a.C), que Xenakis busca problemas e apresenta suas próprias conclusões estéticas. O compositor grego se detém especialmente nos aspectos lógicos e ontológicos destes pensadores para pensar sua estética musical.

Primeiramente Xenakis se apóia no pensamento de Pitágoras, mais propriamente, a chamada escola pitagórica. A perspectiva de mundo destes partia de uma observação no campo musical, as proporções dos sons observada na lira órfica, ou lira tetracorde, e daí a inferência de que a realidade também obedecia proporções e portanto uma visão numérica do mundo (Chauí, 2005:68-69). Segundo Xenakis, é a força da "teoria”, de extrair do mundo uma razão, que é a essência do ser humano, e tem no pitagorismo sua maior expressão e o leva a afirmar que somos todos pitagóricos (Xenakis, 1992: 202).

Uma das preocupações dos filósofos pré-socráticos era acerca da origem, da transformação e desaparecimento dos seres, o devir. Dois filósofos pré-socráticos tomaram posições opostas no que diz respeito ao devir: Parmênides e Heráclito. De acordo com Heráclito apenas a mudança, as transformações, a mutabilidade do ser são verdadeiras e a permanência ilusória. (Chauí, 2005:81) Parmênides tomou posicionamento contrário a

\footnotetext{
${ }^{1}$ Iannis Xenakis formou-se como engenheiro civil no Instituto Politécnico de Atenas. O compositor chegou a concluir o curso, mas de forma um tanto conturbada devido aos acontecimentos decorrentes da Segunda Guerra Mundial. Seu envolvimento como ativista de esquerda durante a guerra culminou com seu exílio em Paris, onde passaria então a viver e desenvolver sua atividades como arquiteto e compositor.
} 
Heráclito afirmando a verdade da permanência, da unidade primordial, indivisível e única do ser, enxergando a realidade visível e mutável como mera aparência, ilusão. (Chauí, 2005:92)

Embora Xenakis citasse comumente os pré-socráticos, nunca deixou de prestar sua dívida com Platão, afirmando algumas vezes as intensas leituras que fizera do livro $A$ República do filósofo (Xenakis, 1987:19 e apud Varga, 1996:13,15,49). A unidade em que resulta uma composição musical permeada pela sucessão de eventos distintos, o peremptório no permanente, resvala de certa maneira em sua própria visão da dialética platônica. Nesse sentido a composição assume o aspecto imutável, uno, indivisível e a definição de suas regras, das menores partes, o desenrolar dos eventos assumem o aspecto mutável, diverso e divisível.

Platão concilia ambos, considerando que Heráclito tinha razão quanto ao mundo sensível, à matéria, aos seres corpóreos, mas estes para Platão eram apenas aparência e também dava razão a Parmênides afirmando a permanência dos seres, onde o mundo verdadeiro é o das essências imutáveis. A síntese dos contrários (peremptório), o embate do ilusório, que tem como objetivo o alcance da verdade, da essência imutável, define o que chamamos de dialética platônica (Chauí, 2005:240-241).

As sucessivas tentativas de explicação do mundo pela razão, segundo Xenakis, sempre estiveram em paralelo com o desenvolvimento da música no ocidente (Xenakis, 1985:99-101). O pensamento platônico, causal e determinista influenciaram a estética musical até o século XIX. No século XX, de acordo com o compositor, há um alargamento do conceito de causa:

\footnotetext{
"A explicação do mundo, e conseqüentemente dos fenômenos sônicos que nos envolve ou que podem ser criados, necessitava beneficiar-se do alargamento do princípio de causalidade, a base deste alargamento é formada pela lei dos grandes números. Essa lei implica numa evolução assintótica em direção a um estado estável, uma espécie de objetivo, stochos, de onde vem o adjetivo 'estocástica'” (Xenakis, 1992: 4)
}

Veremos posteriormente como Xenakis salta do pensamento filosófico para a aplicação matemática em sua música. Retornando a Parmênides, Xenakis retoma seu 
pensamento quando conclui a peça Achorripsis em 1957. Parafraseando o seguinte trecho do Poema de Parmênides: "O mesmo é para ser e pensar"; Xenakis aponta que: "O mesmo é para ser e não ser”, de onde decorre a seguinte ontologia oferecida pelo compositor:

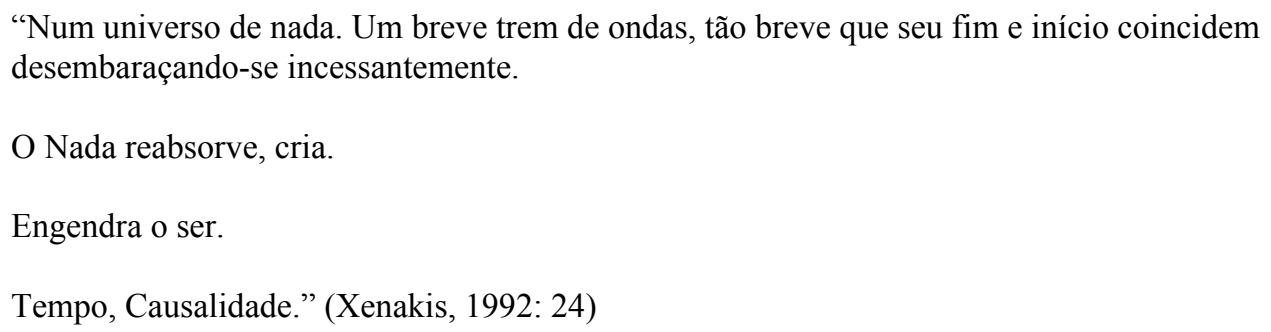

Aqui a filosofia alcança o ponto em que dá lugar à poética no pensamento de Xenakis. A maneira como isso ocorre em suas composições acontece de maneira muito sutil, mas que acompanha uma trajetória iniciada em Metastasis e conclui em Achorripsis. Esse "universo de nada" nos revela como Xenakis se posiciona diante do problema tempo na música. O tempo visto não como mera sucessão de eventos e sim como durações inatas aos eventos sonoros que decorrem ao longo de uma composição. A escolha das durações é estritamente arbitrária: uma folha em branco onde uma sucessão de eventos são inscritas. Tempo marcado, pulsação, ritmo como concebidos tradicionalmente são praticamente irrelevantes. Esse "breve trem de ondas", rarefações e compressões de ar quando percebidos, que definem a escuta, é indissolúvel, único e no entanto diverso em suas características acústicas. Tal brevidade em que tanto "início e fim coincidem desenrolandose infinitamente" nos remete à imutabilidade e unidade de Parmênides.

Cabe aqui abordarmos as três categorias que Xenakis estabelece para tratar do problema tempo: hors-temps, en-temps e temporelle ${ }^{2}$. Uma escala de alturas por exemplo é uma estrutura hors-temps, para qual nenhuma combinação vertical ou horizontal de seus elementos poderá alterá-la. Sua ocorrência é que pertence à categoria temporelle. Portanto, uma melodia ou um acorde numa dada escala é produzida ao relacionar a categoria horstemps à temporelle. A essa relação chamamos de categoria en-temps, de construções horstemps (Xenakis, 1992:183). Para Xenakis é necessária a distinção entre estruturas, arquiteturas, a composição em si de suas ocorrências no tempo. O compositor considera o

\footnotetext{
${ }^{2}$ Mantemos os termos em francês, visando a clareza do pensamento do compositor. Os correspondentes em português mais próximos seriam "fora-do-tempo", "em-tempo" e "temporal". Reportamos o leitor para o quarto capítulo desta dissertação onde as categorias temporais são devidamente abordadas.
} 
tempo como um quadro negro em que símbolos, relações ou organismos abstratos são inscritos.

\footnotetext{
"A batalha entre organismos e arquiteturas e realidade imediata instantânea dá nascimento a qualidade primordial da consciência viva." (Xenakis, 1992:192)
}

Essa "batalha" é possível para Xenakis pelo uso do cálculo de probabilidades que permite lidar com massas de eventos sonoros e moldá-las plasticamente. Tal possibilidade vai além do tradicional posicionamento horizontal e vertical em música devido ao indeterminismo das estruturas en-temps. O tempo para Xenakis não é ponto de partida, o fluir do tempo é congelado quando o compositor grava em sua natureza estruturas préconcebidas, restringindo ou liberando mais ou menos indeterminismo. A estocástica portanto acaba por oferecer toda uma nova gama de possibilidades de organização. Sendo possível até mesmo a inclusão de estruturas hors-temps do passado musical e dessa maneira perfazendo a síntese entre passado, presente e futuro na música. Ritmo num sentido moderno seria uma espécie de design arquitetônico temporal. O compositor oferece ainda uma tentativa de transformar em axiomas as estruturas temporais posicionadas fora do tempo da seguinte maneira:

1. Nós percebemos eventos temporais.

2. Graças à sua divisibilidade, esses eventos podem ser assimilados como marcos territoriais no fluxo do tempo que são instantaneamente trazidos para fora do tempo porque seu traço está em nossa memória.

3. A comparação entre esses marcos nos permite distingui-los em distâncias, intervalos e durações. Uma distância, traduzida espacialmente, pode ser considerada como o deslocamento, o passo, o salto de um ponto a outro, um salto não temporal, uma distância espacial.

4. É possível repeti-los, para ligar esses passos numa cadeia.

5. Há duas orientações possíveis, uma por acumulação de passos, a outra por deispersão. (Xenakis, 1992:265) 
Aqui Xenakis estabelece a união entre Heráclito e Parmênides, erigindo sua estética de uma batalha de eventos singulares tomados em suas ocorrências populacionais, nebulosas, massificadas de características distintas num recorte de tempo. Tais características distintas são aquelas que percorrem os diferentes graus que levam da ordem à desordem ou inversamente, para os diferentes parâmetros acústicos. Se por um lado para construí-las musicalmente os cálculos probabilísticos são requeridos, elas também decorrem de uma observação natural que também obedecem leis estocásticas. Xenakis nos chama atenção para os sons das cigarras durante o verão, o som da chuva, das migrações populacionais de um território para outro, os sons da guerra, da sucessão de lances num jogo de cara e coroa (exemplo usado para ilustrar a lei dos grandes números), todos esses eventos dissociados de seus contextos, são verificados pela estatística. Suas transformações da ordem à desordem, de maneira contínua ou descontínua, e os diferentes graus entre as mesmas formam o imaginário poético do compositor grego.

Em ocasião de sua defesa de doutorado, Xenakis nos oferece sua própria visão de Filosofia:

"Filosofia, mas em que sentido? No sentido do impulso filosófico que nos atrai à verdade, revelação, pesquisa, questionamento geral, interrogação, e áspera crítica sistemática, não apenas em campos especializados, mas em todos os domínios possíveis. Isso nos leva a um conjunto de conhecimentos que deveria ser ativo, no sentido de "fazer". Não conhecimento passivo, mas conhecimento que é traduzido em atos criativos. Eu repito, em todos os domínios possíveis.” (Xenakis, 1985:8)

Tal visão filosófica irá guiar não só as peças do período inicial do compositor mas toda sua obra musical. A combustão provocada pela mutabilidade em Heráclito juntamente com o imutável de Parmênides será constantemente evocada e funcionará como moto propulsor de toda a obra de Xenakis. 


\subsubsection{Algumas Considerações Sobre Lógica}

O surgimento da lógica deu-se na Grécia, no século IV a.C. pelo filósofo Aristóteles (384-322 a.C.). Aristóteles fundou a lógica com a teoria dos silogismos, ou seja, um tipo de argumento que sempre tem duas premissas e uma conclusão. Um exemplo clássico de silogismo é o seguinte: Todos os gregos são imortais (premissa um); Sócrates é grego (premissa dois); logo, Sócrates é imortal (conclusão). A intenção de Aristóteles foi definir tais argumentos, os silogismos e determinar quais deles são válidos. Ainda que outras escolas filosóficas tivessem se dedicado à lógica, como os megáricos e estóicos, apenas a lógica dos escritos aristotélicos permaneceu. Durante a Idade Média, a lógica aristotélica teve um certo desenvolvimento pelos lógicos deste período e assim permaneceu até o século XIX o que era conhecido como lógica.

Tal estagnação fez com que o filósofo Immanuel Kant (1724-1804) afirmasse no prefácio de sua Crítica da razão pura, que Aristóteles criou a lógica em seu estado último de desenvolvimento, e nada mais era possível. No entanto, em meados do século XIX, o desenvolvimento da lógica ganhou um novo impulso com a publicação de Investigação sobre as leis do pensamento, em 1849, de George Boole (1815-1864). Esta publicação iniciou a "simbolização" da lógica, dando-lhe um caráter matemático, transformando-a numa linguagem artificial, o que Aristóteles havia feito em grego. O cálculo lógico apresentado por Boole é hoje conhecido como álgebra booleana e contém um número infinito de formas válidas de argumento. Trinta anos depois da publicação de Boole surge uma outra publicação, de grande importância para a lógica contemporânea, Conceitografia de Gottlob Frege (1848 - 1925). Frege, ao contrário de Aristóteles e até mesmo Boole, buscava a sistematizaçao do raciocínio matemático ao invés de identificar formas válidas de argumento, definir com precisão o que é uma demonstração matemática. A partir de Frege a lógica teve um grande desenvolvimento, e já é até mesmo considerada como uma ciência em particular dissociada da filosofia (Mortari, 2001: 27-29).

Além da identificação de formas válidas de argumento e demonstração matemática, a lógica também passou a ter utilização tal como a representação de informação em geral por meio dela. A ligação de Iannis Xenakis com a lógica contemporânea é intensa a ponto dele fundamentar nela toda sua nova música. Por um lado Xenakis recorre à lógica para 
definir uma linguagem artificial, uma nova simbolização dos dados sonoros, de modo que estes estivessem preparados para interagirem com a matemática e a física exigidas. A notação tradicional não foi designada para lidar com a física e a matemática, embora fosse conseqüência tendo em vista os fins práticos, de execução, ou seja, interpretação da obra. Uma linguagem artificial consiste: num alfabeto, um conjunto de caracteres básicos; e em regras de formação (gramática), um conjunto de regras que define como combinar os caracteres do alfabeto de modo a formar os termos e as fórmulas. Não por acaso os escritos coligidos de Xenakis, sua grande obra teórica, tem o nome de Musiques Formelles (1963), em português algo como "músicas formais", ou ainda como precisamente sugere o título em inglês Formalized Music (1971), "música formalizada". Neste sentido podemos entender que esta "música formalizada" indica o processo de tradução de argumentos musicais para uma linguagem artificial. Enfatizemos que Xenakis se mostrou um tanto reticente quanto ao uso de uma linguagem artificial somente pela linguagem, que em meio a gráficos e símbolos, o sonoro fosse perdido simplesmente pela exaltação do símbolo em detrimento da conseqüência sonora intencionada pelo compositor (Xenakis, 1992:180-181).

Por outro lado Xenakis recorre à lógica, especialmente à álgebra booleana, com a pretensão de reger a macroforma de uma composição musical, como veremos em sua "música simbólica".

\subsection{Fundamentos Físicos e Matemáticos}

Se por um lado Xenakis recorre à Teoria da Probabilidade como fundamento geral de sua Música Estocástica, para fins estritamente práticos Xenakis recorre primeiramente à Lei dos Grandes Números, assim como concebida pelo matemático Jacques Bernoulli. No entanto a Lei dos Grandes Números resultará mais como base intuitiva de sua música do que propriamente numa aplicação. De modo que houvesse uma aplicação generalizada, direcionada a uma composição, o compositor recorre às Teoria Cinética dos Gases e Lei de Poisson num primeiro momento e às Cadeias de Markov posteriormente. Tais escolhas não surgiram prontamente, mas são decorrentes de experiências que o levariam a uma série de testes composicionais iniciadas com Metastasis(1954) e Pithropakta(1955), e concluído em Achorripsis(1956) e Analogique A e B(1958). 
Devemos deixar claro que os princípios matemáticos acima foram usados tendo em vista a organização formal de suas composições. No caso de Metastasis, Pithropakta e Achorripsis tais fundamentos matemáticos também serviram para definir os elementos menores da composição: alturas, dinâmicas e durações. Tomando como base fundamentos retirados da matemática pura, e que não necessariamente correspondiam à atributos físicos específicos como os da acústica, o compositor grego acabou por configurar o caráter experimental destas composições, ainda que mais bem definidas em Achorripsis, onde o compositor generalizou tais fundamentos para toda a composição. Xenakis apenas fez as aproximações necessárias no campo acústico objetivando um resultado "audível". O compositor só recorreria à uma teoria física estritamente acústica ao compor Analogique A e $B$, quando realiza os primeiros experimentos estéticos com os Sinais de Gabor, uma teoria acústica de meados do século XX mas que ainda está sendo explorada.

Ao recorrer à Teoria da Probabilidade, Xenakis legou toda uma nova maneira de enxergar o problema formal no cenário musical do pós-guerra, instigando a busca por novas organizações através da criação incessante de novas regras composicionais, válidas para um grupo ou uma única composição, fossem elas matemáticas ou não. Acusticamente, ao lidar com os Sinais de Gabor, especialmente quando compôs peças como Concret $\mathrm{PH} \mathrm{e}$ Analogique $B$, a primeira concreta e a segunda eletrônica, iniciou todo um campo de investigação que só encontraria sua completa realização em ambiente digital, ainda em progresso. Estamos falando da síntese sonora digital granular ${ }^{3}$, ou seja, a sintetização de sons a partir de grãos sonoros de diferentes características e suas respectivas aglomerações para formação de nuvens sonoras. Investigaremos o contexto em que tais teorias surgiram e como Xenakis apropriou-se esteticamente das mesmas em criação musical.

Ressaltemos o caráter eminentemente experimental da aplicação das diferentes leis de probabilidade, elas jamais significaram um fim em si mesmas como imperativo formal. Ao recorrer à estocástica, Xenakis perpetrou caminhos e fez escolhas de caráter puramente subjetivo, pois como já dissemos, tais leis não foram erigidas com fim musical. O compositor atenta muito mais para a necessidade de novos princípios organizacionais. As

\footnotetext{
${ }^{3}$ Xenakis apenas propôs em suas teorias o que viria a ser chamada de sintese granular, mas não chegou a realizá-la. Na década de 1970 compositores como Curtis Roads e Barry Truax foram os primeiros a criar algoritmos e peças baseadas na sintetização de sons granulares através de computadores. (Chadabe, 1997:257)
} 
teorias de música estocástica nunca foram alçadas ao lugar de substitutas da música tradicional do ocidente, mas sim como abertura à novos caminhos, conclamando toda uma nova geração de músicos para o campo aberto de possibilidades que a abstração matemática pode oferecer.

O compositor também pesquisou intensamente a aplicação da Teoria dos Conjuntos no campo musical. Xenakis realiza composições com base na Teoria dos Conjuntos, notavelmente Herma (1962). Nesta composição utiliza uma notação decorrente da álgebra booleana que por sua vez é proveniente da Teoria dos Conjuntos. A notação algébrica de Boole juntamente com a álgebra linear, irá contribuir para construção de esquemas lógicoformais de uma composição. A peça para piano solo Herma contém conjuntos de frequências que serão conectados de acordo com as leis lógicas dos conjuntos como união, intersecção, adição e subtração. As leis estocásticas agem introduzindo aleatoriedade na ordenação de aparecimento das frequências, dissociando de uma possível identificação com o conceito tradicional de escala ou melodia. Ainda que o compositor tenha enfatizado sua possibilidade teórica, tais leis não foram estendidas para os parâmetros de amplitude e duração, elas seriam generalizadas mais tarde quando propõe um modelo de ferramenta lógica extensível a qualquer parâmetro sonoro, as Sieves (Crivos), ainda que o compositor tenha se dedicado quase exclusivamente ao parâmetro altura.

Novamente enfatizamos que a matemática no ambiente composicional de Xenakis oferece modelos formais inteiramente novos mas não são estritamente musicais, são equivalentes e submetidos às aproximações necessárias que estas necessitam ao longo da confecção de uma composição. Tais aproximações não são uma trapaça matemática como se poderia sugerir, mas necessárias para que não comprometam a escuta ou tornem a composição irrealizável (Arsenault, 2002:62). A complexidade matemática na música de Xenakis só é válida se relevante para a escuta: a música estocástica neste sentido é probabilística em seus princípios formais e não exige do ouvinte uma escuta "matemática". Para Xenakis a matemática pode ser sentida como proporções, no caso da diferença entre um som curto e um longo, mas é irrelevante no caso da solução de uma equação de segundo grau (Zaplitny, 1975:91). Embora o compositor não exija o impossível de uma "escuta matemática" é interessante que o ouvinte conheça os princípios envolvidos na composição 
de maneira a guiar a escuta em seus fundamentos formais. Muitos dos programas de concerto, em ocasião da apresentação de suas peças, continham as respectivas fórmulas e equações utilizadas em sua criação, esperando do ouvinte um "background" mínimo necessário para que fossem compreendidas (Zaplitny, 1975:93).

Investigaremos abaixo cada um dos tópicos matemáticos e físicos citados acima, apresentando assim conceitos que serão novamente retomados quando tratarmos especificamente de sua utilização e confecção das composições de música estocástica.

\subsubsection{Teoria da Probabilidade}

Quando abordamos o aspecto filosófico do pensamento de Xenakis, lançamos um pequeno olhar para o papel das probabilidades em sua música, pretendemos nos deter um pouco mais sobre elas, clarificando sua própria natureza a fim de elucidar suas aplicações musicais. Inicialmente podemos conceituar a natureza das probabilidades partindo da seguinte definição:

“...um homem se propõe a avaliar a probabilidade de um acontecimento $\mathbf{A}$, ele considera, de um lado a natureza do acontecimento $\mathbf{A}$, e, de outro tudo que conhece com respeito às várias possibilidades capazes de favorecer ou desfavorecer a realização de $\mathbf{A}$. ...podemos designar por $\mathbf{K}$ o corpo de conhecimento que intervém no cálculo da probabilidade. Assim podemos chamar esta probabilidade de $\mathbf{P}(\mathbf{A}, \mathbf{K})$, isto é, a probabilidade do acontecimento A em relação ao corpo de conhecimentos K.” (Borel, 1956:12)

Esta probabilidade $\mathbf{P}(\mathbf{A}, \mathbf{K})$, resume quase todo campo de investigação da teoria das probabilidades, principalmente se entendemos que $\mathbf{K}$, pode ser incompleto ou falso. $\mathrm{O}$ corpo de conhecimentos de $\mathbf{K}$ é incompleto, por exemplo, quando pretendemos prever o tempo em longos prazos, embora uma observação estatística nos forneça dados mais ou menos precisos, eles nunca são totalmente seguros. Neste caso a probabilidade ocorrência de $\mathbf{A}$ é incerta devida à indeterminação de $\mathbf{K}$. Da mesma maneira $\mathbf{K}$ também pode conter inúmeros erros, estes então irão falsificar a obtenção da probabilidade de A. Por exemplo, um jogador aposta que irá escolher, ao acaso, cinco cartas de um baralho completo, se sair um cinco de espadas ele ganha. Mas o jogador desconhece o baralho, não sabe que é falsificado e não contém a carta cinco de espadas, portanto o corpo de conhecimento do jogador, acerca de $\mathbf{K}$, é falso e ainda que haja a eminência da ocorrência do evento $\mathbf{A}$, a 
escolha da referida carta, nunca irá ocorrer. Aqui adentramos num campo de estudos fértil para o estudo das probabilidades: o dos jogos de azar. Tais jogos baseiam-se na probabilidade equalitária de ocorrência de eventos, independentemente de sua repetição: um dado lançado numa superfície horizontal guarda as mesmas possibilidades de ocorrência para cada uma das faces; um baralho guarda as mesmas chances de distribuição para todas as cartas; num lance de moedas, as faces cara ou coroa têm a mesmas chance de ocorrência.

Dadas as definições básicas vamos aos conceitos comumente utilizados por Xenakis: a) Lei dos Grandes Números; b) Lei de Poisson; c) Cadeias de Markov; d) Teoria Cinética dos Gases.

\subsubsection{Lei dos Grandes Números}

Embora Xenakis tenha citado inúmeras vezes a Lei dos Grandes Números, não fez uso prático dela. Como vimos acima, o compositor a toma em seu sentido filosófico, identificando a mesma com o alargamento do conceito platônico de causa. A Lei dos Grandes Números foi enunciada pela primeira vez no séc. XVIII, pelo matemático Jacques Bernoulli. O exemplo comumente tomado para exemplificar a lei é o lance de cara ou coroa, em que um número relativamente grande de lances, da ordem de 30.000 por exemplo, implica no não prevalecimento de uma face sobre outra. A frequência de ocorrência de um dado evento, numa sequência de lances reiterados, tende para um limite igualitário e estável. Devemos enfatizar que este é um modelo abstrato, não corresponde à realidade, pois uma moeda pode ter uma das faces irregulares assim como superfície onde os lances acontecem. O mesmo é válido para um dado. No caso do dado, por exemplo, a freqüência de ocorrência para cada uma das faces, se fizermos 50.000 lances, é igual. A lei dos grandes números não é observável para uma pequena quantidade de lances de cara ou coroa ou de dados, da ordem de 10 ou 50 lances, em que uma das faces, do dado ou da moeda podem prevalecer.

Ao vislumbrarmos a Lei dos Grandes Números no âmbito compositivo de Xenakis, verificamos que ao distribuir no espaço sônico, massas de diferentes características, ele não o faz de maneira que estas tomem um rumo qualquer mas sim fazendo com que elas 
atinjam um estado, uma certa estabilidade, de acordo com as regras estabelecidas para determinada peça. De acordo com as próprias palavras do compositor, a perspectiva é que os menores detalhes definam os maiores:

"Quando eu olho para um pequeno número de indivíduos, eu os vejo como indivíduos; enxergo suas relações, suas características, e suas relações com o espaço e o tempo, suas próprias fisionomias, etc. Mas se há uma população, eu já não distingo os indivíduos, porque são numerosos. Ao contrário, posso enxergar os aspectos, as características da população.” (Xenakis, 1985:34)

Para o compositor, quando usa como material um glissando simples, pizzicatos, a gravação de um pequeno estalo, ou a sintetização de um pequeno som senoidal, estes nada valem isoladamente e sim quando acumulados e dissociados dando lugar a diferentes formações durante uma composição. A Música Estocástica portanto é probabilística apenas da perspectiva numerosa, da aglomeração, das massas e nunca da probabilidade de ocorrência de um pequeno número de eventos. Verificamos esta perspectiva tanto na criação de música estocástica livre quanto na markoviana.

\subsubsection{Lei de Poisson}

Uma das decorrências da Lei dos Grandes Números é a Lei de Poisson ${ }^{4}$, que implica numa distribuição de eventos num intervalo discreto de tempo. Por exemplo, a chegada de chamadas numa central telefônica, durante um certo tempo. Consideremos as chamadas como eventos e uma unidade de tempo em que elas ocorrerão. A Lei de Poisson é então aplicada para a probabilidade de $\mathbf{x}$ eventos ocorrerem num subintervalo da unidade de tempo.

"Vamos imaginar um intervalo de tempo unitário dividido em $\mathbf{n}$ subintervalos de comprimento $\mathbf{1} / \mathbf{n}$. O fato do intervalo conter um número finito de pontos pode ser encarado como o resultado de um processo casual no qual cada subintervalo tem a mesma probabilidade Pn de conter um ou mais pontos do conjunto. Um subintervalo qualquer estará então ocupado ou vazio...” (Feller, 1976:136)

A ocorrência de eventos tais como chamadas telefônicas num determinado espaço de tempo é casual, mas sua distribuição passível de ser deduzida, e com isso uma espécie de simulação desse tipo de ocorrência probabilística. Tomando como base esse tipo de

\footnotetext{
${ }^{4}$ Denis Poisson (1781-1840), físico e matemático francês.
} 
distribuição Xenakis compõe toda uma peça, Achorripsis (1956), inteiramente governada pela Lei de Poisson. O compositor pretendia compor usando um mínimo de regras e ater-se a uma grande possibilidade de assimetria. De acordo com Xenakis, ao designar uma dada distribuição e recortar um fragmento suficientemente grande desta, obtém-se uma peça musical (Xenakis, 1992:23). Esta mesma distribuição seria pouco depois automatizada por computadores comissionados pela $I B M$, através de um software desenvolvido pelo compositor chamado $S T$ (estocástica). O software deu origem ao círculo de peças também conhecidas como $S T$, livrando a composição dos fastidiosos cálculos manuais, que na época ainda contavam com calculadoras um tanto rudimentares. A assistência de computadores em composição musical é portanto pioneira através da iniciativa de Xenakis.

O compositor estabelece duas hipóteses, necessárias, ao optar pela Lei de Poisson:

1. Há um dado espaço, instrumentos musicais e homens;

2. Há meios de contato ente esses homens que permitem a emissão de raros eventos sônicos. (Xenakis, 1992:24)

É por meio dessas duas hipóteses que Xenakis pela primeira vez relega inteiramente ao acaso uma peça musical, tornando estético algo que até então não era. A criação assim como empreendida pelo compositor ao longo de Achorripsis(1956) o levou a defini-la como um "jogo de xadrez para um único jogador”, pois as sucessivas tentativas de distribuição dos eventos nos espaços delimitados para a composição, até chegar ao resultado final, são semelhantes às dinâmicas exigidas por um jogo, mas cuja vitória é a conclusão da peça em que as regras propostas satisfaçam todas as exigências requeridas pela composição(Xenakis, 1992:32). 


\subsubsection{Cadeias de Markov}

O matemático russo A.A Markov (1856-1822) formulou a teoria que leva seu nome para descrever a evolução de caracteres em textos escritos. Uma cadeia de Markov indica as probabilidades de um evento A ser seguido de um evento B. Para isso uma Matriz de Probabilidades de Transição é elaborada da seguinte maneira:

$\begin{array}{llll} & \text { A } & \text { B } & \text { C } \\ \text { A } & 0.1 & 0.9 & 0 \\ \text { B } & 0.33 & 0.33 & 0.34 \\ \text { C } & 0.8 & 0.1 & 0.1\end{array}$

As colunas representam os possíveis eventos prévios e as fileiras os possíveis eventos que irão se seguir. A matriz acima indica que um evento A terá $10 \%$ de chance de ser seguido de um mesmo evento A ou que um evento B terá 34\% de chances de seguir um evento C (Roads 2001:67). Uma Matriz de Probabilidades de Transição pode ser aplicada a diferentes parâmetros sonoros como freqüência, amplitude ou densidade.

A utilização das Cadeias de Markov foram intencionadas como um modo de adicionar memória no interior do mecanismo de uma composição. Tomando três eventos sonoros de características distintas, a aleatoriedade que condiciona suas existências na composição não é totalmente desgovernada como acontece em Achorripsis, cuja distribuição é livre, mas com um encadeamento intrínseco. Não significa, como se poderia pensar, que uma composição que siga certas matrizes de transição seja rigidamente determinista e causal como ocorre na música tradicional. A causalidade aqui vale para um único esquema compositivo já que diferentes matrizes de transição podem ser configuradas, com um grande número de eventos, e dessa maneira dando origem à composições completamente diferentes umas das outras, cujo determinismo é singular. Xenakis compôs duas peças interligadas, fazendo uso das Cadeias de Markov, entre os anos de 1958 e 59 , Analogique $A$ e $B$. A primeira $(A)$ para orquestra de cordas e a segunda $(B)$ composta com pequenos sons senoidais gravados em fita magnética. Embora tenham sido compostas para 
serem executadas separadamente, podiam ser sincronizadas eventualmente, denominada Analogique $A+B$.

\subsubsection{Teoria Cinética dos Gases}

Xenakis recorre à Teoria Cinética dos Gases, assim como formulada por Maxwell e Boltzmann na metade do séc. XIX, como sustentação de sua música estocástica. O compositor grego propõe uma equivalência entre massas gasosas e massas sonoras e estas obedecendo princípios semelhantes às primeiras. Quando compõe Pithropakta (1955), a teoria cinética auxilia sua construção ao atribuir uma característica gasosa aos glissandos. No entanto sua aplicação é destinada, aparentemente, apenas a um trecho da composição, não deixa claro se fundamentou toda a composição (Xenakis, 1992:15). Outros conceitos que fazem parte do corpo da Teoria Cinética dos Gases como entropia, ordem e desordem, serão retomados quando compõe Analogique $A$ e $B$.

Uma massa gasosa é constituída de um número grande de moléculas em estado de agitação perpétua. A cada instante de sua agitação, as moléculas se chocam constantemente umas contra as outras e contra a parede do recipiente em que se encerram. A velocidade é influenciada pela temperatura do recipiente onde quanto maior ela é, maior é a velocidade dos choques das moléculas. A massa de cada molécula é um fator importante sendo proporcional à sua velocidade. Sob mesma temperatura, o quadrado médio da velocidade é inversamente proporcional à massa da molécula. Por exemplo, a massa da molécula de oxigênio é 16 vezes maior que a massa da molécula de hidrogênio, à mesma temperatura a velocidade média da molécula de hidrogênio será 4 vezes maior que a de oxigênio. Considerando o percurso livre médio das moléculas, a distância percorrida entre um choque e outro, e uma densidade relativamente grande, em condições normais de pressão e temperatura, sofrem um alto número de choques. A cada choque entre duas moléculas a velocidade é alterada, permanecendo constante o quadrado de suas velocidades, assim a distribuição das velocidade muda rapidamente e em pouco tempo a temperatura torna-se uniforme. Essa é a definição da Teoria Cinética dos Gases assim como definidas por Maxwell e Boltzmann. 
Uma experiência comum para ilustrar a teoria cinética é a mistura de dois gases. Consideremos dois recipientes idênticos, cada um com um gás diferente sob condições normais de pressão e temperatura, comunicados por um tubo fechado por uma torneira. Ao abrirmos a torneira verifica-se que após um tempo, relativamente curto, ambos os recipientes conterão uma mistura homogênea de gases, mantida indefinidamente. Isso ocorre devido ao movimento aleatório das moléculas. O acaso impõe à velocidade das moléculas sua repetição não apenas ao conjunto das diversas moléculas num dado instante, mas também ao conjunto das velocidades sucessivas de uma mesma molécula durante um certo período. Conseqüentemente, após um intervalo de tempo relativamente longo em relação ao intervalo que separa dois choques, cada molécula terá iguais probabilidades de se encontrar em cada recipiente e teremos então uma mistura homogênea dos gases.

Esta homogeneidade alcançada em certo tempo implica no princípio de evolução: em um sistema fechado, que não recebe energia de uma fonte exterior, evolui passando de estados menos prováveis para outros mais prováveis. Isso significa que um sistema fechado jamais passará pelo mesmo estado duas vezes. Aqui nos deparamos com um novo conceito: a entropia. Quando consideramos um sistema fechado cuja temperatura é uniforme dizemos que sua entropia é zero, a possibilidade do sistema evoluir é nula, seu estado de organização é portanto homogêneo, alcançou seu estado final. A lei de evolução enuncia que "a entropia de um sistema fechado diminui constantemente". O enunciado nos remete ao campo das probabilidades pois a entropia é igual ao valor absoluto do logaritmo da probabilidade e conseqüentemente quando a probabilidade cresce de 0 para 1 , a entropia decresce de infinito para 0 . Para entendermos melhor essa comparação devemos recorrer ao conceito de freqüência relativa em probabilidades. A freqüencia relativa f é representada pela fração $\mathbf{r} / \mathbf{n}$ onde $\mathbf{r}$ é o número de ocorrências de um certo evento e $\mathbf{n}$ é a quantidade de experimentos realizados. Por exemplo, se lançarmos 1000 vezes uma moeda e nestes lançamentos obtermos 500 vezes a face "cara" então a freqüência relativa é 500/1000, ou seja, simplificando obtemos a fração _ ou 0,5 . Isso significa que se nosso experimento é o lançamento de uma moeda sempre teremos duas possibilidades de ocorrência, cara ou coroa, e sempre que lançarmos a moeda apenas uma das faces pode ocorrer. No caso de um dado a freqüência relativa é igual a $1 / 6$ ou aproximadamente 0,16 . Suponha que a freqüência relativa de um certo experimento é igual a $1 / 1$ ou 1 , isso significa que há 
somente um evento possível verificado. Um sistema fechado, ao evoluir do estado heterogêneo (estado menos provável) até o estado homogêneo (estado mais provável), passa por sucessivas freqüências relativas de 0 até 1. A relação das crescentes freqüências relativas de um sistema fechado é inversamente proporcional à entropia pois esta como vimos é decrescente, ou seja, entropicamente um estado heterogêneo assume um valor numérico infinitamente grande e quando atinge o estado homogêneo é nulo ou 0.

Ao invés de falarmos em probabilidades de um estado podemos nos referir à ordem e a desordem de um sistema. Como vimos, a ordem de um sistema é menos provável que a desordem de um sistema fechado equivalente ao seu estado de homogeneidade. Assim quando a entropia de um sistema é nula isso significa que seu estado é de desordem completa. Partindo desse conceito é possível obter diferentes graus de ordem e desordem que se configuram ao longo da evolução de um sistema. Entre ordem e desordem há uma gama de combinações e organizações muito grande. (Borel, 1956:55-68)

A partir desse ponto voltamos aos princípios compositivos de Xenakis. Ao fornecer as bases de música estocástica Xenakis se volta para uma cadeia de raciocínio emprestada da Teoria Cinética dos Gases, conceitos como homogeneidade, evolução, entropia e ordem e desordem adentram o território da criação musical. O compositor compreende um som qualquer como uma espécie de molécula, com características próprias como duração, freqüência, timbre e amplitude, posicionadas em algum lugar ao longo da duração total do sistema, cujo correlato musical é a composição. Uma composição, por exemplo, pode simular a evolução total de um sistema, da ordem à desordem, como pode também corresponder a um trecho específico ao longo de sua evolução ao ir de um estado de ordem parcial à um outro estado de desordem parcial. Uma composição também pode conter a ocorrência de sistemas simultâneos, sincrônicos ou não, simétricos ou assimétricos, em que enquanto um evento evolui de um estado ordenado para um estado desordenado outro pode traçar o caminho contrário, possuindo características e temporalidades distintas (Xenakis, 1992:25). O compositor age como uma espécie de controlador do acaso, gerenciando quantificações, leis, densidades, especificação de parâmetros acústicos, etc., de acordo com suas intenções criativas. 
O termo molécula utilizado num primeiro momento como modelo teórico dará lugar ao conceito de grão sonoro, sons que de acordo com o compositor permitem variação contínua. Entre as possíveis variações que um grão sonoro poderia assumir, Xenakis utiliza aquela que se tornaria conhecida: o glissando simples, como executado em instrumentos de corda não trasteados. Segundo o compositor um glissando pode ser assimilado sensorialmente como velocidade, aquela mesma que permite o choque entre moléculas. Uma velocidade-glissando nesse sentido é representada através de um vetor unidimensional, onde a hipotenusa do triângulo retângulo é o tamanho do vetor e os dois outros lados correspondem à duração e ao intervalo melódico. Um glissando em direção às altas freqüências é positivo e às baixas negativo.

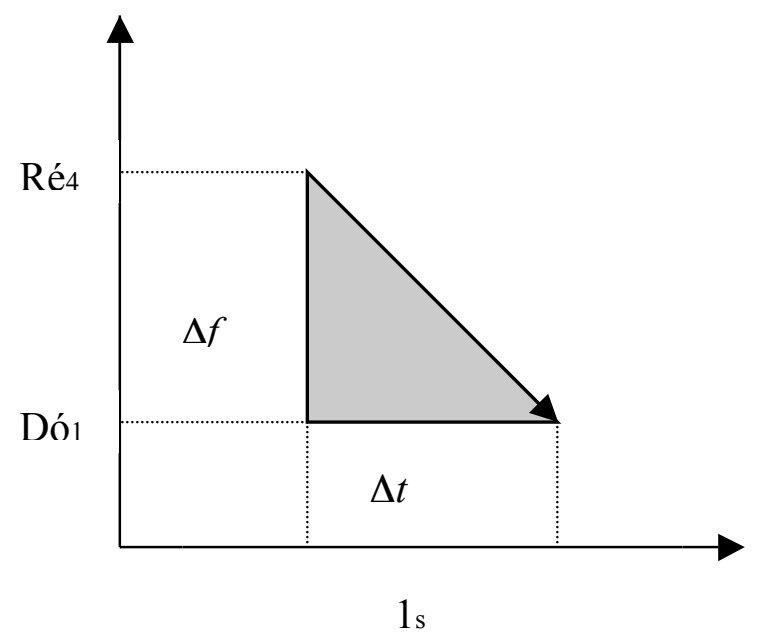

Fig. 1.1 - O gráfico representa um glissando descendente onde $\Delta f$ é uma região de freqüências e $\Delta t$ é uma duração qualquer.

As hipóteses que levariam o compositor a utilizar diferentes modos de distribuição são aquelas da homogeneidade. Partindo do estado último de um sistema fechado, a desordem total que, como vimos, é a homogeneidade da mistura de gases de características distintas, Xenakis elabora hipóteses semelhantes para tratar de sons granulares.

Hipóteses de Homogeneidade

1. A densidade de velocidades sonoras é constante. Duas regiões de igual extensão de alturas contém o mesmo número médio de sons móveis (glissandos). 
2. O valor absoluto de velocidades (glissandos ascendentes ou descendentes) é distribuido uniformemente. O valor médio dos quadrados das velocidades é o mesmo em diferentes registros.

3. Há Isotropia. Não há nenhuma direção privilegiada para os movimentos dos sons móveis em qualquer registro. Há um número igual de sons ascendendo e descendendo. (Xenakis, 1992:1314)

Tomando estas três hipóteses como uma espécie de correspondente musical de uma mistura gasosa homogênea composta de gases distintos, é possível então impor perturbações, distribuições, estratégias de densificação que simulem graus intermediários entre ordem e desordem. Pithropakta (1955-56) é dessa forma uma ruptura completa com a abordagem tradicional, de verticalidade e horizontalidade, pois a notação tradicional como vimos é consequência e não ponto de partida. No entanto esse alto grau de formalização inspirada pela Teoria Cinética dos Gases não foi aplicada para toda a composição, isso só ocorreria em Achorripsis (1956-57) quando Xenakis generaliza as probabilidades para toda uma composição. A despeito da brevidade de um trecho de Pithoprakta o compositor tenta demonstrar que massas sonoras de transformação contínua são possíveis e podem ser controladas através da teoria da probabilidade e com isso apresentar todo um novo universo de organização musical.

\subsubsection{Teoria dos Conjuntos}

Em meados do séc. XIX, as ciências tinham a preocupação de propor modelos teóricos que dessem conta dos aspectos qualitativos, além dos quantitativos acerca dos fenômenos. A Teoria dos Conjuntos surgiu como uma linguagem que desse conta de todos os modelos de maneira precisa, concisa e que abrangesse tanto os modelos já existentes quanto aqueles que surgiriam. Neste tópico iremos apresentar os conceitos básicos desta teoria assim como Xenakis empregou em criação musical.

Não há uma definição precisa do que é um conjunto. Ele é formado por objetos que por sua vez são chamados de elementos. Entre os elementos de um conjunto, podemos ter também outros conjuntos. O símbolo utilizado para indicar que um elemento pertence a um conjunto é $\in$. Se a letra $C$ designa o conjunto dos compositores, e a letra $x$ denota Xenakis, 
representamos a sentença "Xenakis é um compositor" da seguinte forma: $x \in C$. Caso Xenakis não pertença ao conjunto dos compositores representamos: $x \notin C$.

Há duas maneiras de representar os conjuntos: pela enumeração e pela descrição. $\mathrm{Na}$ primeira listamos os elementos de um conjunto, e na segunda descrevemos por meio de uma propriedade comum aos elementos.

Enumeração: \{Xenakis, Ligeti, Bach\} .

Descrição: $\{\mathrm{x} \mid \mathrm{x}$ é um compositor $\}$.

No caso da descrição, não existe uma restrição que a todo conjunto haja uma propriedade comum aos elementos, desse modo o conjunto $W=\{70$, boi, transistor $\}$ é um conjunto legítimo, sua propriedade seria de que "x é um elemento de W", mas como descrição seria redundante. Cabe fazer uma distinção entre intenção (ou conotação) e, em contrapartida, a sua extensão (ou denotação). Por exemplo, a expressão "homens gregos" se refere a certos indivíduos que têm esta característica no universo. Seu conjunto constitui sua extensão e o modo pelo qual nos referimos a eles constituem sua intenção.

Há dois conjuntos especiais, o conjunto vazio e o conjunto universo. Por exemplo, a partir da propriedade "x é diferente de si mesmo" formamos o conjunto $\{\mathrm{x} \mid \mathrm{x}$ é diferente de x \}. Contudo, não existe um indivíduo que seja diferente de si próprio, o conjunto acima não tem elementos, é o chamado conjunto vazio, denotado pelo símbolo $\varnothing$. Assim como o conjunto vazio, existe o conjunto dos indivíduos $x$ que são idênticos a si mesmos, que inclui todos os objetos do universo, temos portanto o conjunto universo denotado pelo símbolo U. Convém deixar claro que um conjunto universo indica todos os elementos que nos interessa numa dada situação, ou seja, o universo do qual falamos é o universo de discurso. Há ainda os conjuntos unitários como $\{j\}$, que têm apenas um elemento.

Dado um conjunto $A$ e um conjunto $B$, se cada elemento do primeiro for também elemento do segundo, chamamos esta relação de inclusão e dizem que $A$ está contido em $B$, ou que $A$ é subconjunto de $B$. Representamos essa relação da seguinte maneira: $A \subseteq B$. 
Os conjuntos $A$ e $B$ podem ter os mesmos elementos e ser o mesmo conjunto, mas se $A$ é diferente de $B$, definimos uma relação de inclusão própria entre dois conjuntos, formalizada como: $A \subset B$. A inclusão própria apenas indica que o mesmo conjunto tem nomes diferentes.

Temos ainda as operações sobre conjuntos. Dados dois conjuntos $A$ e $B$ podemos obter seu conjunto união que contém os elementos de ambos. Denotamos por: $A \cup B$. Se um elemento pertence tanto a $A$ quanto $B$, temos a operação de intersecção e seu conjunto contém apenas os elementos em comum que denotamos por: $A \cap B$. Dado um conjunto universo $\mathrm{U}$, e um conjunto $A$ contido em $\quad \mathrm{U}$, chamamos este de complemento de $A$, simbolizado por $\bar{A}$, que são todos os elementos do conjunto universo exceto aqueles que pertence ao conjunto $A$. Chamamos de diferença entre conjuntos se um elemento pertence a um conjunto $A$ mas não a $B$, que denotamos por: $A-B$.

$\mathrm{O}$ conjunto potência (ou conjuntos das partes) de A é formado pelo conjunto de todos os subconjuntos $A$ que denotamos por $\mathrm{P}(A)$. Por exemplo se $\mathrm{A}=\{1,2\}$, então $\mathrm{P}(A)=$ $\{\varnothing,\{1\},\{2\},\{1,2\}\}$. De um modo geral, dado os $n$ elementos de um conjunto, o conjunto de suas partes será igual a $2^{n}$ elementos. Vale dizer que o conjunto vazio é subconjunto de qualquer conjunto, pois se não fosse o caso então teríamos um elemento que não pertence a um conjunto $A$ mas pertence ao conjunto vazio, o que é absurdo.

A última operação possível entre conjuntos é o produto cartesiano de dois conjuntos $A$ e $B$. Para isso precisamos da noção de par de elementos, assim como temos o conjunto unitário, se temos um conjunto com dois elementos de par. Mas um conjunto não admite ordem, de modo que $\{1,2\}=\{2,1\}$. Podemos introduzir uma certa ordem a um par pela noção de par ordenado, colocando os elementos entre parênteses ao invés de chaves, e dessa maneira $(1,2)$ é diferente de $(2,1)$. Assim como temos pares ordenados podemos ter também triplas ordenadas, quádruplas e da mesma maneira n-uplas, ou ênuplas. Chamamos de produto cartesiano de dois conjuntos $A$ e $B$, que denotamos por $A \times B$, o conjunto dos pares ordenados onde $x \in A$ e $y \in B$. Por exemplo se $A=\{1,2\}$ e $B=\{a, b\}, \mathrm{o}$ produto cartesiano é $A \times B=\{(1, \mathrm{a}),(1, \mathrm{~b}),(2, \mathrm{a}),(2, \mathrm{~b})\}$. Podemos ter também o produto 
cartesiano de um conjunto por ele mesmo que denotamos por $A^{2}$, ou seja, $A \times A$. O produto cartesiano de um conjunto por ele mesmo $n$ vezes é $A^{n}$, e $A^{1}$ é o próprio $A$.

Partindo da noção de par ordenado podemos entender o que é uma relação binária, dados dois indivíduos $x$ e $y$, podemos ter uma relação do tipo " $x$ é maior que $y$ " que denotamos $x \mathbf{R} y$. O símbolo $\mathbf{R}$ indica que há uma relação entre dois indivíduos. Temos três tipos de relação: simétrica, reflexiva e transitiva. Uma relação simétrica é quando uma relação implica outra, por exemplo a relação " $x$ tem o mesmo peso que $y$ " indica que $x \mathbf{R} y$ implica $y \mathbf{R} x$. A relação reflexiva é quando um indivíduo está numa relação consigo mesmo, isto é, $x \mathbf{R} x$. Uma relação é chamada de transitiva quando $x \mathbf{R} y$ e $y \mathbf{R} z$ implica que $x \mathbf{R} z$. Uma relação que é reflexiva, simétrica e transitiva chamamos de relação de equivalência. $\mathrm{O}$ mesmo vale para relações $n$-árias, ou seja, para conjuntos de ênuplas.

Por último consideremos o conceito de função. Uma relação é chamada de função quando num par ordenado $(x, y)$ atribuímos o primeiro elemento $x$ ao segundo $y$. Para que uma relação entre os conjunto $A$ e $B$ seja uma função, em $B$ deve haver exatamente um elemento para cada elemento em $A$. Nesta função $f \operatorname{de} A$ em $B$, chamamos $A$ de domínio de $f$, e $B$ de contradomínio de $f$. Os elementos do domínio $A$ são os argumentos de $f$, e os elementos do contradomínio $B$, de valores de $f$. Um elemento de $B$ é chamado de imagem se é associado por $f$ a um elemento de $A$. A aplicação de $f$ a algum elemento pertencente a $A$ representamos por $f(x)$. Desta maneira denotamos o fato de que $y$ é uma imagem de $x$ pela função $f: f(x)=y$. O conjunto imagem de $f$ é o conjunto dos valores que são imagens por $f$ de algum elemento de $A$. No caso do conjunto imagem de uma função ser igual ao seu contradomínio, chamamos esta de sobrejetora, e se cada elemento do domínio tem uma imagem diferente esta é chamada de injetora. Uma função injetora e sobrejetora é chamada de bijeção ou correspondência biunívoca. Por exemplo, considere a função $f(x)=x+2$, para cada valor que $x$ assume teremos um valor y definido pela função $x+2$, se tomamos o conjunto dos naturais então teremos um conjunto infinito de pares ordenados: $\{(0,2),(1,3)$, $(2,4) \ldots\}$. (Mortari, 2001: 42-54)

A teoria dos conjuntos como vimos acima fundamenta não só a música simbólica de Iannis Xenakis, como também qualquer linguagem formal oferecida pelo compositor já que 
seu conjunto universo, isto é, seu universo de discurso, é constituído pelos elementos sonoros. Delimitações, relações, funções do universo sonoro são necessárias antes de desembocar diretamente numa linguagem como veremos adiante.

\subsubsection{Sinais de Gabor}

O físico britânico Dennis Gabor propôs uma nova teoria acústica em fins do decênio de 1940 e início de 50. Numa série de três textos fundamentados na física quântica e em experimentos práticos (1946, 1947 e 1952), Gabor propõe que qualquer som pode ser considerado uma sucessão de unidades discretas de energia acústica, ou seja, qualquer som pode ser decomposto em uma família de funções obtidas pela mudança de tempo e freqüência obedecendo uma curva de Gauss, que determina a igualdade do início e decaimento do som, sua envoltória.

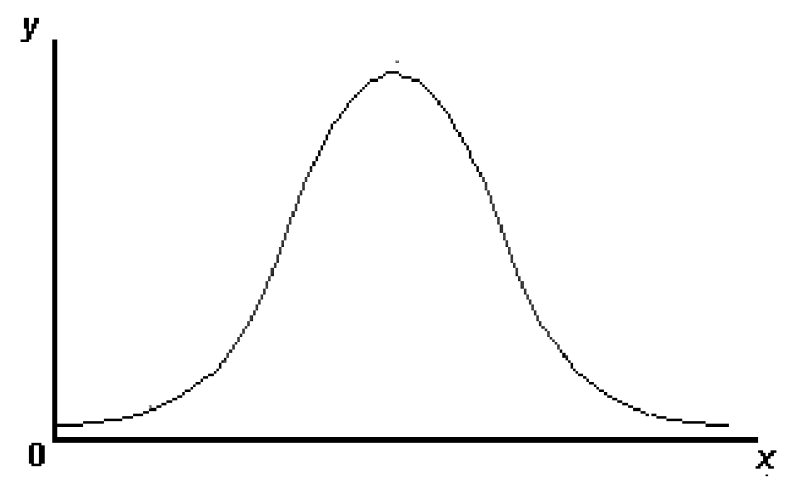

Fig 1.2 - Gráfico representativo de uma curva de Gauss. No caso de um sinal de gabor o eixo y seria a amplitude e o eixo x a duração do sinal.

Isso significa que qualquer som pode ser decomposto em milhares de grãos. (Roads 2001: 57). Dessa forma um som complexo será descrito pela sucessão de grãos sonoros, em diversas freqúências ao longo de uma duração específica, sendo que cada grão tem a sua própria freqüência e duração, localizados nos eixos de tempo e freqüência. 
A teoria de Gabor se opõe à descrição física das transformações de Fourier $^{5}$ até então comumente utilizadas para designar um som. Uma transformação de Fourier permite analisar uma curva ou variação sonora e de pressão de som (amplitude) por meio de funções matemáticas de trigonometria: seno e coseno. A obtenção de um som complexo por exemplo se dá através da adição de inúmeras ondas de comportamento periódico que irão compor o espectro sonoro. O serialismo integral em sua vertente eletrônica sintetizava sons complexos através das transformações de Fourier. De acordo com Xenakis tais transformações não seriam suficientes nem adequadas para confeccionar uma massa sonora, composta de grãos sonoros, como as que vinha construindo em suas composições orquestrais (Zaplitny, 1975:94). Suas peças eletroacústicas irão encontrar nos sinais de Gabor a fundamentação teórica e experimental necessárias para tratar tanto de sons prégravados, quanto para sintetização de sons. Tais experimentos são notáveis na composição Concret PH (1958), peça concreta, em que realiza seus primeiros experimentos com base nos sinais de Gabor junto ao grupo de Pierre Schaeffer na Rádio Nacional Francesa. O material consiste na captação de sons de carvão queimando, estilhaçando, gravados em fita magnética. Xenakis extraiu então inúmeros sons curtos que correspondiam a pequenos estalos e cliques que foram então agrupados, e submetidos à estratégias empíricas de densificação e a diferentes manipulações possíveis com fita magnética em estúdio eletroacústico. A composição resulta numa malha complexa, de grãos sonoros descontextualizados de sua fonte original, caracterizando um artefato sonoro com diferentes escalas de tempo e densificações escondidas na peça como um todo. A peça é percebida pela escuta como uma espécie de timbre flutuante, um nevoeiro robusto e com raros padrões periódicos (Di Scipio, 1998: 214). O passo seguinte foi levar as experiências iniciadas no campo concreto para a sintetização eletrônica com Analogique B (1958-59) em que utilizaria os sinais de Gabor para sintetizar os grãos sonoros que seriam então submetidos à estratégias propostas pelas Cadeias de Markov.

\subsection{MúsiCA ESTOCÁSTICA E ACASO Na MúSICA dO SÉC. XX}

Em 1954, Xenakis escreve o artigo "A crise da música serial” apresentando o que considerava como problemas no cenário da música neo-serial e suas próprias soluções.

\footnotetext{
${ }^{5}$ Jean-Baptiste Joseph Fourier (1761-1840), físico e matemático francês.
} 
Segundo o compositor o artigo serviu como uma ponte para o modo como aplicou matemática em música. Para Xenakis a complexidade da polifonia linear compromete a escuta, incapaz de seguir as linhas do tecido polifônico e tornando a percepção de nada mais que um amontoado de notas em vários registros. Problema que segundo o compositor os compositores neo-seriais não haviam encarado devido à complexidade e da estrita causalidade que esses compositores afirmavam. Xenakis aponta portanto a solução no artigo:

"De fato, quando combinações lineares e suas sobreposições polifônicas deixarem de operar, contará o meio estatístico de estados isolados e a transformação dos componentes sônicos num dado momento. $\mathrm{O}$ efeito macroscópico pode ser controlado por meio dos movimentos dos elementos que escolhemos. O resultado é a noção de probabilidade que implica, neste caso particular, em cálculo combinatório" (Xenakis, 1992:8).

Se para Xenakis, a possibilidade do acaso em música só é possível através de cálculos matemáticos, o mesmo não acontecerá para outros dois compositores do mesmo período: o norte-americano John Cage e o francês Pierre Boulez. Numa de suas composições, Music of Changes (1951) o compositor John Cage se utiliza do método de adivinhação chinês I Ching, para especificar os parâmetros da composição, as operações de acaso (Terra, 2000:79-80). No caso de Boulez, compositor serialista, em sua peça Estruturas Ia (1951) trabalha com uma série de operações no interior da série, extraindo o máximo de mobilidade, a chamada música aleatória (Terra, 2000:110). Xenakis considera ainda que há um mau uso semântico, por esses compositores, das palavras "acaso" e "aleatório", que para ele têm conotação estritamente matemática. De acordo com Xenakis, o "acaso" pode ser construído até certo ponto, matematicamente, mas nunca improvisado ou imitado intelectualmente (Xenakis, 1992: 38-39).

\subsection{MÚSICA E DESENHO ARQUITETÔNICO}

Seus conhecimentos em arquitetura antiga, bem como a realização de projetos arquitetônicos junto à equipe do arquiteto Le Corbusier contribuíram decisivamente para o desenvolvimento de novos procedimentos em composição. O período com Le Corbusier, paralelo aos estudos musicais do compositor, inicia-se em 1948 e estende-se até 1960. Para Xenakis, durante esses doze anos, tanto os problemas arquitetônicos como os musicais 
estavam intimamente relacionados. Quase todos os projetos arquitetônicos nesse período foram abordados do ponto de vista musical.

No projeto do Couvent de la Tourette (1953- 57), o design de sua fachada foi concebido a partir de escolhas no âmbito musical. A fachada do convento dispõe grandes placas de vidro arranjadas verticalmente em camadas superpostas de intervalos e densidades irregulares. Segundo Xenakis (Varga, 1996:127), o projeto da fachada, é proveniente do estudo de padrões rítmicos que estava realizando na época.

É no projeto do Pavilhão da Philips na Exposição Mundial de Brussel (1958) em que estreita ainda mais as relações entre design arquitetônico e composição musical. O projeto foi desenvolvido a partir da partitura de Metastasis, sua primeira composição usando novos procedimentos. A respeito da criação de Metastasis (1953-54), Xenakis disse o seguinte:

"Eu possuía uma fantasia visual (linhas retas, por exemplo, então glissandos vieram a mim naturalmente) que eu poderia transformar em fantasia auditiva e v ice-versa" (Vargas, 1996:47-48).

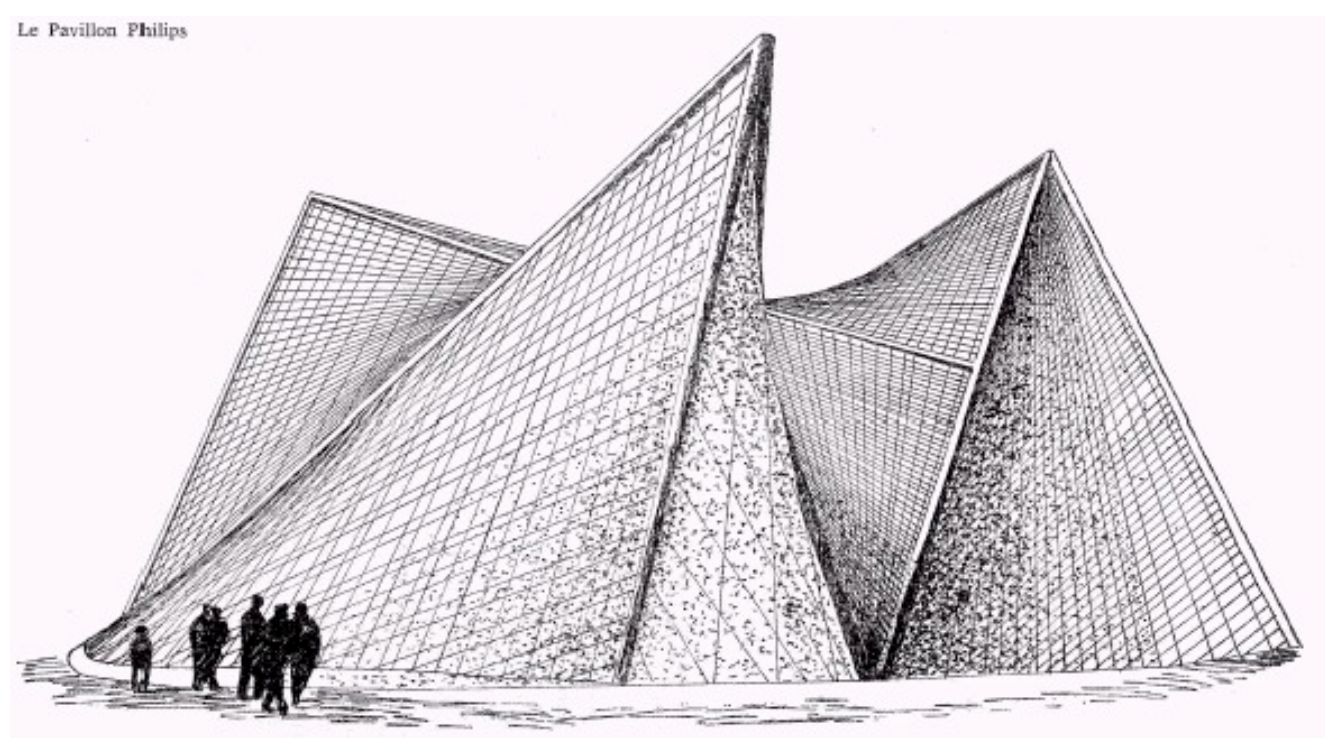

Fig 1.3 - Design do Pavilhão Philips

Mas Xenakis também aborda o problema do ponto de vista estrutural. De acordo com o compositor a tradição enfatiza a criação musical a partir de células, frases, temas e motivos que darão origem à forma geral de uma peça. Segundo o compositor deveria ser o 
contrário, a forma, a estrutura geral deveriam ser o primeiro passo e somente em seguida, ou paralelamente, viria a definição dos menores elementos de uma composição (Zaplitny, 1975:90). Os longos anos lidando com desenho arquitetônico levou o compositor muitas vezes a tratar do problema organizacional em seu processo compositivo de maneira arquitetônica, partindo primeiramente da elaboração de esboços visuais para depois vislumbrar uma possível construção sonora, quando então os elementos menores da composição seriam pensados. 


\section{Música Estocástica}

Neste capítulo abordaremos o desenvolvimento da música estocástica de Iannis Xenakis. Iniciaremos tecendo um breve estudo de sua trilogia de composições Anasteria (1953-1954) não concluída, a peça seguinte foi Metastasis (1954). Esta última seguida da peça Pithoprakta (1955) são o início das concepções do que viria a ser de fato a música estocástica com a peça Achorripsis (1956). Concomitantemente à apresentação das peças segue também a exposição da construção do edifício teórico que dá embasamento às peças. Por último vamos abordar o ciclo de peças $S T$, criadas através de um dispositivo tecnológico, um software de mesmo nome desenvolvido pelo compositor.

\section{$\underline{\text { 2.1 Anasteria }}$}

As duas peças da trilogia inconclusa de Xenakis, Procession aux claire e Sacrifice, ambas de 1953, indicam a passagem de um projeto bartokiano àquele mais abstrato das peças seguintes. Projeto bartokiano porque a intenção de Xenakis era beber nas características folclóricas presentes na tradição musical grega e refleti-las em composição musical. Estas peças combinam a tradição musical grega e elementos da vanguarda européia. Anasteria foi inspirada num ritual popular da região grega da Trácia.

A composição La Procession aux euax claires foi escrita para orquestra, coro misto e masculino e dura pouco mais de dez minutos. A tradição musical grega aparece no coro masculino, uma espécie de cantus firmus monódico baseado no aleluia da liturgia de São João Crisóstomo. Xenakis ao compor as melodias se interessa muito mais pela sua redução à escala que propriamente pelo seus aspectos melódicos. Reduzidas a escalas, estas revelam o aspecto vanguardista pelo tratamento combinatório das melodias. Essas combinações, bem como suas justaposições, prefigurariam as massas sonoras presentes em seus trabalhos posteriores.

A peça Sacrifice para orquestra, dedicada a Olivier Messiaen, é a obra que precede Metastasis. Esta peça é notável pelo abandono do projeto bartokiano, pois já não faz referência às melodias folclóricas gregas, é uma peça abstrata. Tem duração de quase cinco minutos. A obra é caracterizada por um mecanismo que submete uma escala a diferentes 
proporções da seção áurea. (Solomos, 2003:1-19). Deste modo passamos a Metastasis cuja concepção é mais rigorosa.

\section{$\underline{\text { 2.2 Metastasis }}$}

Metastasis, de 1954, foi concebida por Xenakis como a terceira peça da trilogia Anasteria. No entanto a peça tinha alcançado um tal grau de abstração que já não podia ser englobada naquele conjunto de peças. Entre a primeira peça da trilogia e Achorripsis (1956) há um grau crescente de complexidade, um desenvolvimento. Metastasis está situada no meio deste desenvolvimento, pois ao mesmo tempo que significa uma ruptura com as preocupações estéticas que norteavam aquelas primeiras peças, é também o início de uma abordagem mais abstrata. Neste sentido Metastasis é o início do projeto estocástico de Xenakis e que também o tornaria conhecido como compositor (Varga, 1996, 52).

Duas eram as preocupações de Xenakis em meados da década de 1950: 1) compor uma peça dodecafônica com a ajuda de computações, uma peça cuja macroforma fosse erigida a partir de alguns princípios básicos; e 2) mudança contínua de acordes, ou seja, um acorde que se transforma em outro sem que entre eles haja qualquer quebra de continuidade. A principal questão colocada neste momento era como mudar uma coisa que é contínua. Daí o nome Metastasis, um contraste entre duas palavras de origem grega, meta que significa sucessão espacial ou temporal, e stasis que significa imobilidade. A solução empregada foi a combinação da utilização de glissandos e computações baseadas na permutação de intervalos, partindo de uma abordagem axiomática de caráter matemático. Ao compor Metastasis, o compositor chegou à conclusão que para lidar com um grande número de eventos teria que recorrer ao estudo das probabilidades matemáticas. Nesta peça o problema ainda foi relegado a uma abordagem intuitiva. Só recorreria de fato às probabilidades, como veremos, quando compõe Pithoprakta em 1955 (Varga, 1996:73).

Composta para orquestra de 61 instrumentos, Metastasis apresenta ênfase na utilização das cordas entre instrumentos de percussão, metais e madeiras. A estrutura de intervalos, durações, dinâmicas e timbres obedecem a progressões geométricas, 
especialmente a seção áurea ${ }^{1}$. A macroestrutura da peça tem três seções, cada uma com partes distintas. A duração da peça tem uma duração aproximada de nove minutos. A primeira e terceira seções têm uma estrutura similar, caracterizada pela massa sonora de glissandos sobre as cordas, enquanto que a segunda seção, porção central da obra, é caracterizada por uma estrutura mais intrincada.

A primeira seção vai do compasso 0 a 103, e tem duas partes: a primeira vai do compasso 0 a 55 e a segunda do compasso 55 ao 103. Esta primeira parte se inicia com uma grande massa de glissandos que vai do compasso 0 ao 34. Os primeiros e segundos violinos, num total de 24, e as oito violas, realizam movimentos ascendentes de glissandos, e os oito violoncelos e seis contrabaixos realizam movimentos descendentes de glissandos. Esta movimentação de glissandos dá lugar a um cluster massivo ao fim do compasso 34, mesclando ao timbre das cordas, metais e percussão. O que é notável nestes 55 compassos da primeira parte é uma combinação de divisões baseadas na seção áurea tomando como base números da série de Fibonnacci. A dinâmica evolui de $p p$ a $f$ nos primeiros 34 compassos, e de $f$ a $f f f$ nos 21 compassos seguintes. Temos, portanto, duas partes claramente baseadas na seção áurea, que por sua vez também apresentam divisões distintas através de números de Fibonnacci em seu interior. Os 34 primeiros compassos são desta maneira subdivididos em 13 e 21 compassos; os primeiros 13 distinguem-se do segundo por apresentarem mais uma subdivisão de 8 e 5 compassos. Estes 8 e 5 compassos dos primeiros 13 compassos da primeira parte dividem os glissandos das cordas, o primeiro que se inicia no compasso 1 até o 8 , e o segundo do 8 ao 13. A partir do compasso 13 os

\footnotetext{
${ }^{1}$ A progressão geométrica conhecida como seqüência de Fibonnacci é uma seqüência de números inteiros $\mathrm{u}_{n}$ em que $n \geq 0$ e tal que, para $n \geq 2$ o termo obtido é a soma dos dois termos precedentes, ou seja,

$$
\mathrm{u}_{n}=\mathrm{u}_{n-1}+\mathrm{u}_{n-2} \text {. }
$$

Desta maneira $\mathrm{u}_{1}=\mathrm{u}_{0}=1$, como o índice dos dois primeiros números da seqüência é menor que dois, e a seqüência é de números inteiros, não pode ser 0 , então os dois primeiros inteiros da seqüência são iguais a 1 . $\mathrm{O}$ terceiro número da seqüência é igual 2, pois $\mathrm{u}_{2}=\mathrm{u}_{2-1}+\mathrm{u}_{2-2}=2$, os dois termos precedentes são iguais a 1, e para o índice 2 o termo obtido é igual a 2 . A seqüência obtida através desse procedimento é: 1, 1, 2, 3, $5,8,13,21,34,55,89,144,233 \ldots$; estes são os números de Fibonnacci. A razão obtida entre dois números consecutivos da seqüência de Fibonnacci, $\mathrm{u}_{n+1} /{ }_{n} \mathrm{u}$ converge para o número de ouro. Chamamos de número de ouro ou proporção divina o limite $\phi$, quando $n$ tende ao infinito, a razão entre dois termos consecutivos da seqüência de Fibonnacci. Ele é um número real algébrico, raiz real positiva da equação $\mathrm{x}^{2}+\mathrm{x}+1=0$. $\mathrm{O}$ valor dessa raiz positiva é o limite $\phi$ que tem valor aproximado de 1,618033989. Este é o número correspondente à razão da seção áurea, sua proporção. (Santana, 1998:20).
} 
glissandos aparecem de modo mais rápido, quase compasso a compasso. O espaço compreendido entre o compasso 21 e 34 apresenta novamente uma nova divisão, de 13 e 8 compassos, sendo que os 13 primeiros se subdividem em mais 8 e 5 compassos. Estes primeiros 13 compassos apresentam uma dinâmica que vai de $f$ a $f f$, os 8 primeiros compassos se caracterizam pelos glissandos simples, os outros 5 acrescentam pizzicatos. Os próximos 8 compassos acrescentam aos glissandos simples e aos pizzicatos, vibratos e apresentam uma dinâmica que vai de $f f$ a $f f f$. Xenakis joga com diferentes sobreposições da seção áurea, para criar camadas proporcionais baseadas num mesmo princípio matemático, isto somente nos primeiros 55 compassos da primeira parte.

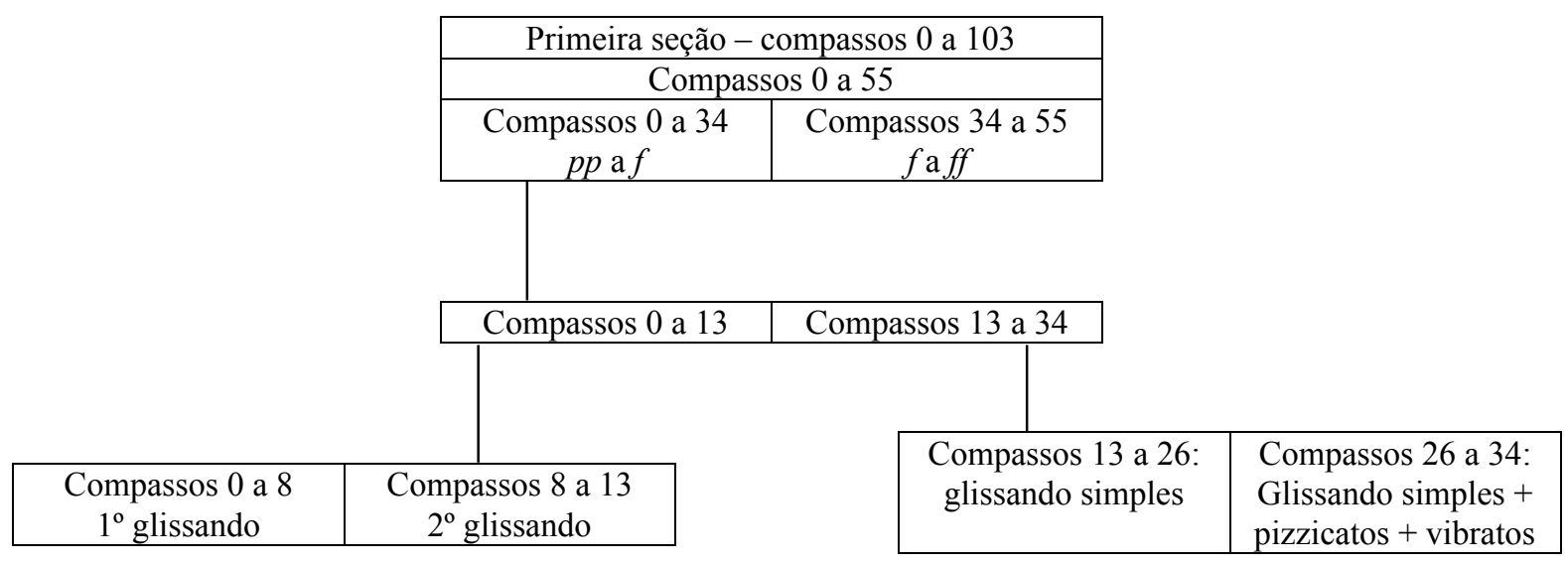

Fig. 2.1 - Diagrama da primeira parte de Metastasis.

A segunda seção que vai do compasso 104 a 201 tem uma estrutura um pouco mais complexa e de caráter serial. Esta tem três partes distintas, sendo a primeira do compasso 104 ao 149, a segunda do 150 ao 173, e a terceira do 174 ao 201. De acordo com o compositor ele utiliza as vozes de uma maneira singular, como se fossem pincéis:

"Na seção média da composição eu usei pequenos pincéis onde um centro é circundado apenas pelas doze notas centrais. Se, digamos, que o Dó é um centro de gravidade, então seis notas sobem até F\#, e seis descem também até F\# mas uma oitava abaixo. Em outras palavras tomamos um pequeno pincel que se abre. Podemos então transpô-lo, estendê-lo e contraí-lo no tempo. Aqui, então, as duas idéias básicas de Metastasis (mudança contínua e descontínua) são fundidas.” (Xenakis apud Varga, 1996: 73) 
A primeira parte, que vai do compasso 104 ao 149, utiliza os primeiros violinos, violoncelos e contrabaixos para obter uma mistura homogênea de timbres, através de recursos sonoros das cordas como ponticello, com e sem surdina, legato, e normal. A dinâmica é $m f$ durante toda a parte. A segunda parte, que vai do compasso 150 ao 173 , apresenta um novo timbre com harmônicos, em dinâmica $p p$, com surdina. Os segundos violinos apresentam sons entre normal e sul ponticello. Mais uma vez temos números baseados na seção áurea, os segundos violinos iniciam normalmente depois de cinco compassos do início dessa parte e após 13 compassos do início, no compasso 167, todos os instrumentos executam um $f f f$, cinco compassos depois essa parte termina. A terceira parte e última parte desta seção vai do compasso 174 a 201. Além dos timbres já mencionados, temos aqui a adição de percussão e nos segundos violinos a execução em col legno e tutti. Esta seção é portanto caracterizada pela variação sutil de timbres, quase exclusivamente apoiada nas cordas, através de transformações no interior de uma única característica sonora (cordas) e dessa maneira variações dentro do homogêneo e uno como havia explicitado o compositor.

A terceira seção vai do compasso 202 ao 345, é a maior parte da peça e é caracterizada pela utilização de toda a massa orquestral, cordas, madeiras, metais e percussão. As sonoridades contrastantes se opõem e se unificam. Temos duas partes nesta seção, a primeira que vai do compasso 202 ao 316, e a segunda que vai do 317 ao 345 . A primeira parte é notável pela construção de blocos de timbres distintos e opostos nas cordas utilizando todos os recursos já vistos nas outras seções. A dinâmica funciona em blocos ao contrário daquelas evolutivas vistas nas primeira e segunda seções. A segunda parte é a conclusão da obra, que retoma os princípios observados no início da primeira parte, a massa 
sonora de glissandos e a utilização de sobreposições da seção áurea com dinâmicas no timbre das cordas (Santana, 1998: 267-281).

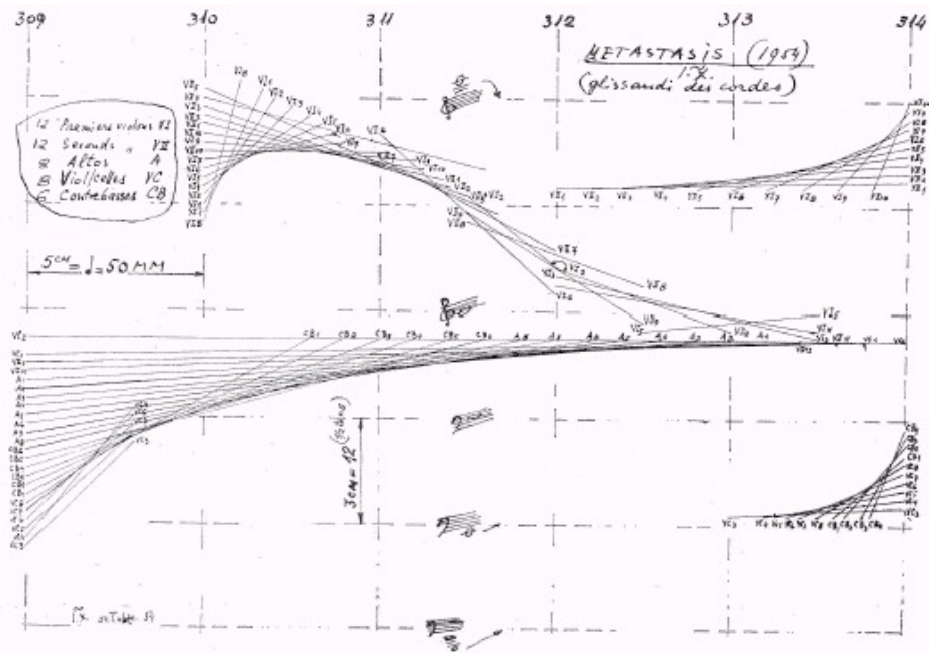

Fig 2.2. Gráfico do plano de glissandos correspondentes aos compassos 309 a 314 (Xenakis: 1962). 


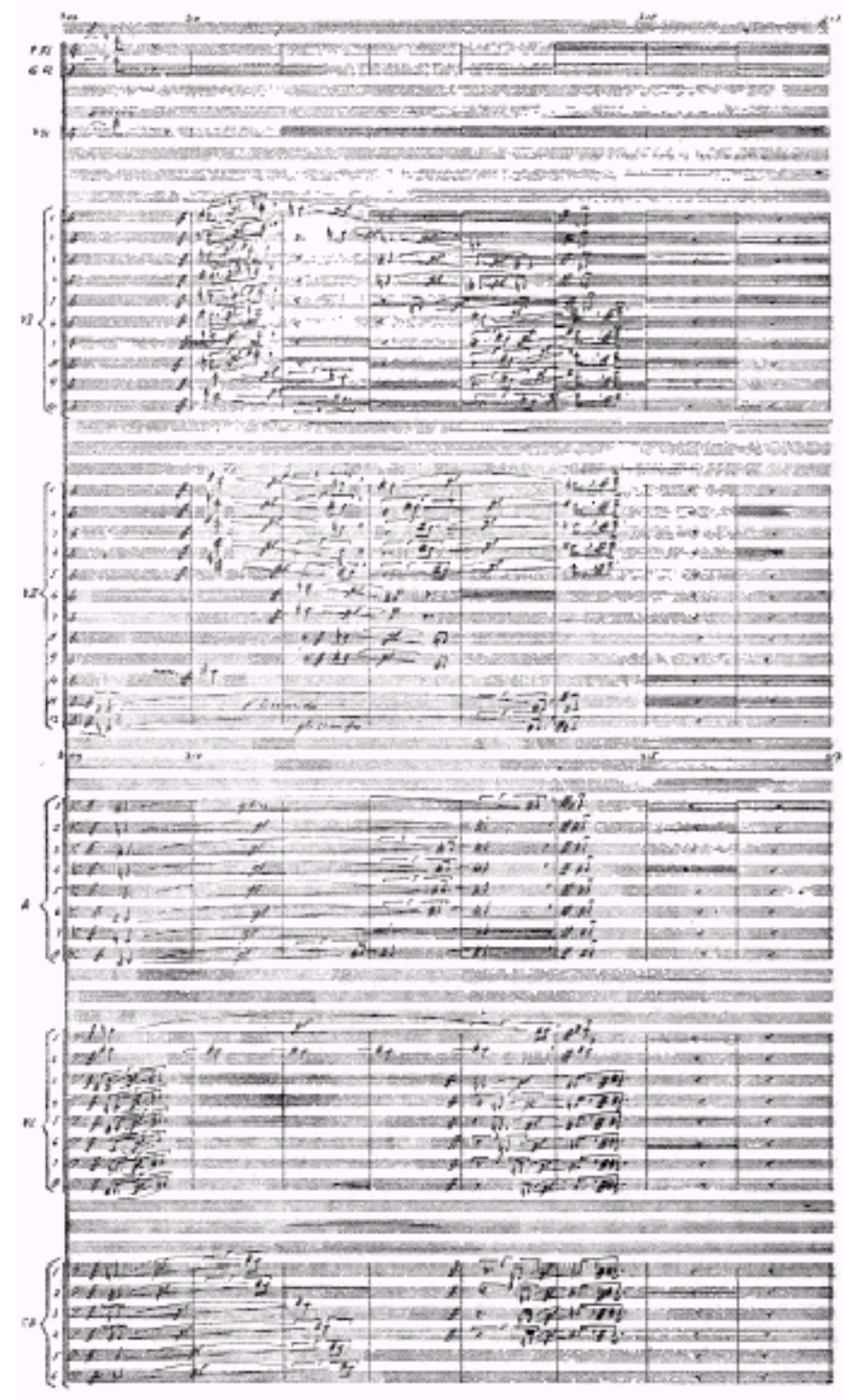

Fig. 2.3 - Partitura de Metastasis, compassos 309 a 317 (Xenakis, 1992: 2).

Como vimos, Metastasis ${ }^{2}$ tem ainda fortes traços seriais, sua principal fundamentação matemática, baseada na seção áurea, é ainda um tanto simples se comparada com a complexidade das obras seguintes. Apesar de Xenakis ter dedicado um

${ }^{2}$ Gravação realizada pela Orchestre National de l' O. R. T. F sob regência de Maurice Le Roux; selo Le Chante du Monde, 2001. Partitura Metastaseis, 1967, Boosey \& Hawkes. 
tempo considerável à confecção de Metastasis, sentia que as questões que o levaram a compô-la não estavam completamente resolvidas. Decidiu pôr um fim na peça e partir para novas questões compositivas despertadas com a criação de Metastasis. Na peça seguinte Pithoprakta, ele começou a lidar com a questão de massa sonora de maneira mais meticulosa (Varga, 1996:75).

\subsection{Pithoprakta}

Pithropakta (1955-56) é uma ruptura com a abordagem tradicional, de verticalidade e horizontalidade, pois a notação tradicional é conseqüência e não ponto de partida. A palavra Pithoprakta, em grego, significa "produto da previsão", ou "ações da probabilidade" (D’Allones, 1990:36). Para Xenakis, a construção da peça não tem como espaço primeiro a partitura em branco, esta só será preenchida após a realização dos cálculos, esquemas, etc, enfim, o desenho global da peça. A notação tradicional é exigida apenas para fins de execução e interpretação, é conseqüência de uma criação musical realizada fora do âmbito horizontal e vertical da partitura. Portanto, não é possível inferir a estrutura de uma obra de Xenakis diretamente pela análise de sua respectiva partitura. Tal inferência só é possível se compreendidos os procedimentos peculiares tomados pelo compositor fora do âmbito tradicional. Essa ação compositiva própria do compositor não estava totalmente consolidada durante a realização de Metastasis e Pithoprakta. O agir compositivo abstrato que vai até princípios científicos para então abordar o sonoro encontra-se ainda mesclado com um agir compositivo tradicional. Por vezes Xenakis infere sua obra partindo de conceitos matemáticos e físicos abstratos, estranhos à música, adaptando conceitos, fórmulas e equações a parâmetros sonoros. Por outro lado o compositor muitas vezes age diretamente na partitura, mas não oferece nenhum traço de como faz isso. A preocupação do compositor é demonstrar seu agir compositivo abstrato, como vai do pensamento científico à partitura, abolindo gradualmente deste processo o agir compositivo tradicional. Na medida em que abole o agir compositivo tradicional Xenakis não dá nenhuma importância à suas próprias reminiscências oriundas da tradição, estes resíduos se perdem quanto mais polariza-se no agir abstrato. Deste modo, Xenakis dá a entender que formalização inspirada pela Teoria Cinética dos Gases não foi aplicada globalmente a Pithoprakta, de maneira uniforme, baseada num único princípio. Isso só 
ocorreria em Achorripsis (1956-57) quando Xenakis generaliza as probabilidades para toda uma composição.

De acordo com Xenakis:

"Pithoprakta é um salto no desconhecido. Eu fui guiado apenas pelas idéias que eu tinha acerca da macroforma" (Xenakis apud Varga, 1996:75).

A peça ${ }^{3}$ foi concebida para orquestra de 50 instrumentos, sendo 12 primeiros violinos, 12 segundos violinos, 8 violas, 8 violoncelos, 6 contrabaixos, 2 trombones tenor, xilofone e blocos de madeira. Embora a ênfase da obra seja nas cordas, estas foram utilizadas de modo que pudessem oferecer uma extensa gama de timbres, incluindo sons percussivos realizados com os arcos no corpo dos instrumentos. É no interior dessa variedade de timbres que Xenakis teve a idéia de recorrer a procedimentos estatísticos para transformar uma nuvem de sons percussivos, pizzicatos, em sons contínuos de glissandos. De acordo com o compositor a peça recorre quase que inteiramente à utilização de probabilidades para tratar da questão temporal, não há nenhum traço de aplicação da seção áurea. No entanto, sua confecção levou meses, pois o compositor passou um longo tempo estudando e experimentando fórmulas probabilísticas que pudessem ser aplicadas. Além disso precisava ter familiaridade com elas de modo que essas fórmulas estivessem sempre em mente e à mão para que pudesse aplica-las. Xenakis compôs as diferentes partes da peça separadamente, fazendo diagramas e buscando os parâmetros das fórmulas que tivessem correspondentes sonoros. Apenas o conhecimento das fórmulas não era suficiente para assegurar que sonoridades pudessem ser ativadas, era preciso estar sempre alerta para a conseqüência sonora. Neste sentido, Pithoprakta não revela uma abordagem tão unitária da macroforma, era muito mais centrada na experimentação científica aplicada à música. Por essa razão, o próprio compositor fornece poucos dados em seus escritos sobre como a peça foi construída em sua abordagem global. Xenakis nos oferece apenas um exemplo preciso: a pequena porção da música que vai do compasso 52 ao 60 .

\footnotetext{
${ }^{3}$ Gravação Gravação realizada pela Orchestre National de l' O. R. T. F sob regência de Maurice Le Roux; selo Le Chante du Monde, 2001.
} 
Esta diminuta porção, de quase 20 segundos, dentro da peça que tem uma duração aproximada de quase 10 minutos, apresenta uma massa sonora evolutiva de grãos sonoros, pizzicatos. Esses poucos segundos, no entanto, revelam uma laboriosa construção. Em papel quadriculado Xenakis construiu um gráfico que visualmente representa uma pequena transição de um estado à outro de uma massa sonora. Primeiramente o compositor escolheu um valor de temperatura para o conjunto de velocidades proporcional à $a=35$. O tempo foi representado em unidades de $5 \mathrm{~cm}=26 M M$ (metrônomo Mälzel), que podiam ser subdividas em três, quatro ou cinco partes iguais permitindo pequenas variações de duração. As alturas foram representadas em unidades de um semitom correspondente à $0.25 \mathrm{~cm}$ e dessa maneira $1 \mathrm{~cm}$ corresponde a uma terça maior. A partir destes dados uma fórmula de probabilidade ${ }^{4}$ forneceu uma tabela de velocidades (glissandos) que seriam então distribuídas, modelando plasticamente o material. A composição sonora deste material atende às seguintes características: as durações não variam; as alturas são livremente moduladas; a densidade sonora é constante; a dinâmica ff não varia; o timbre é constante; as velocidades determinam uma "temperatura" sujeita à flutuações locais cuja distribuição é Gaussiana. O gráfico obtido foi então transcrito em notação tradicional e corresponde aproximadamente à 18.5 segundos (Xenakis, 1992:15).

"Eu segui a abordagem de Maxwell passo a passo: o que ele fez com as moléculas eu fiz com sons" (Xenakis apud Varga, 1996:78)

${ }^{4}$ Uma função $\mathrm{f}(\mathrm{x})$ como vimos associa a cada valor de $\mathrm{x}$ um outro valor, ou seja, para cada valor $\mathrm{x}$ do domínio temos um valor y no contradomínio. A função que Xenakis utiliza é a "distribuição gaussiana". Essa distribuição, originalmente mostra que, numa série de medidas experimentais, os desvios se distribuem em torno de um valor médio segundo uma curva de sino. Porém o uso de Xenakis é outro, ele utiliza para que a mesma forneça um conjunto de velocidades, a tabela de probabilidades de acordo com a função abaixo:

$$
\mathrm{f}(v)=\frac{2}{a \sqrt{\pi}} e^{-v^{2} / a^{2}}
$$

Onde $a$ é a temperatura do sistema como vimos no texto, cujo valor é 35 . O número $e$ é um número irracional, base dos logaritmos naturais, seu valor aproximado é $\cong 2,718$. Como correspondente sonoro, para cada velocidade Xenakis utilizou um glissando curto, em pizzicato. Um total de 1148 velocidades foi obtido e distribuídos de acordo com a lei de Gauss. Essa lei afirma que o fluxo de linhas numa superfície fechada é proporcional à massa dentro dessa superfície, ou seja, a quantidade de velocidades que se movem é sempre a mesma. 


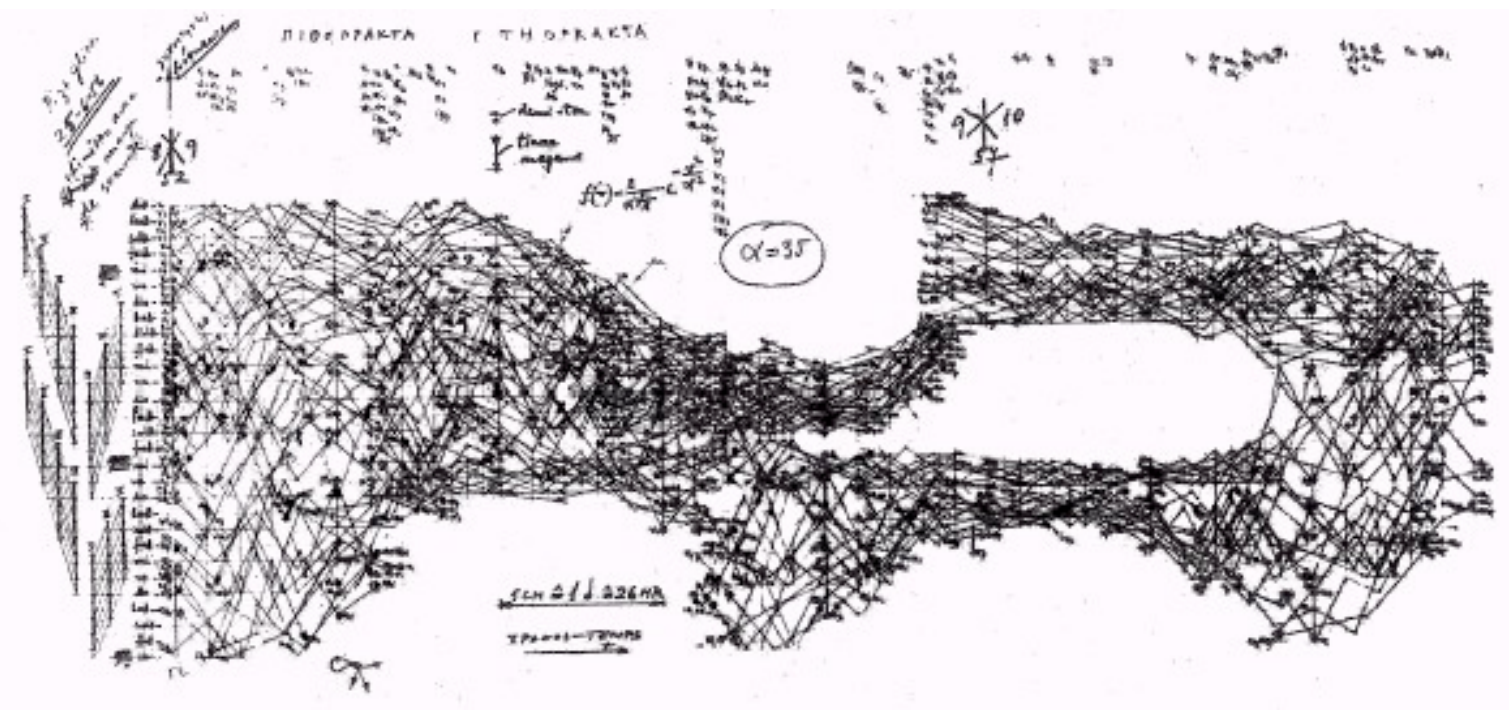

Fig 2.4 - Gráfico correspondente aos compassos 52 a 57 da peça Pithoprakta (Xenakis: 1962). 


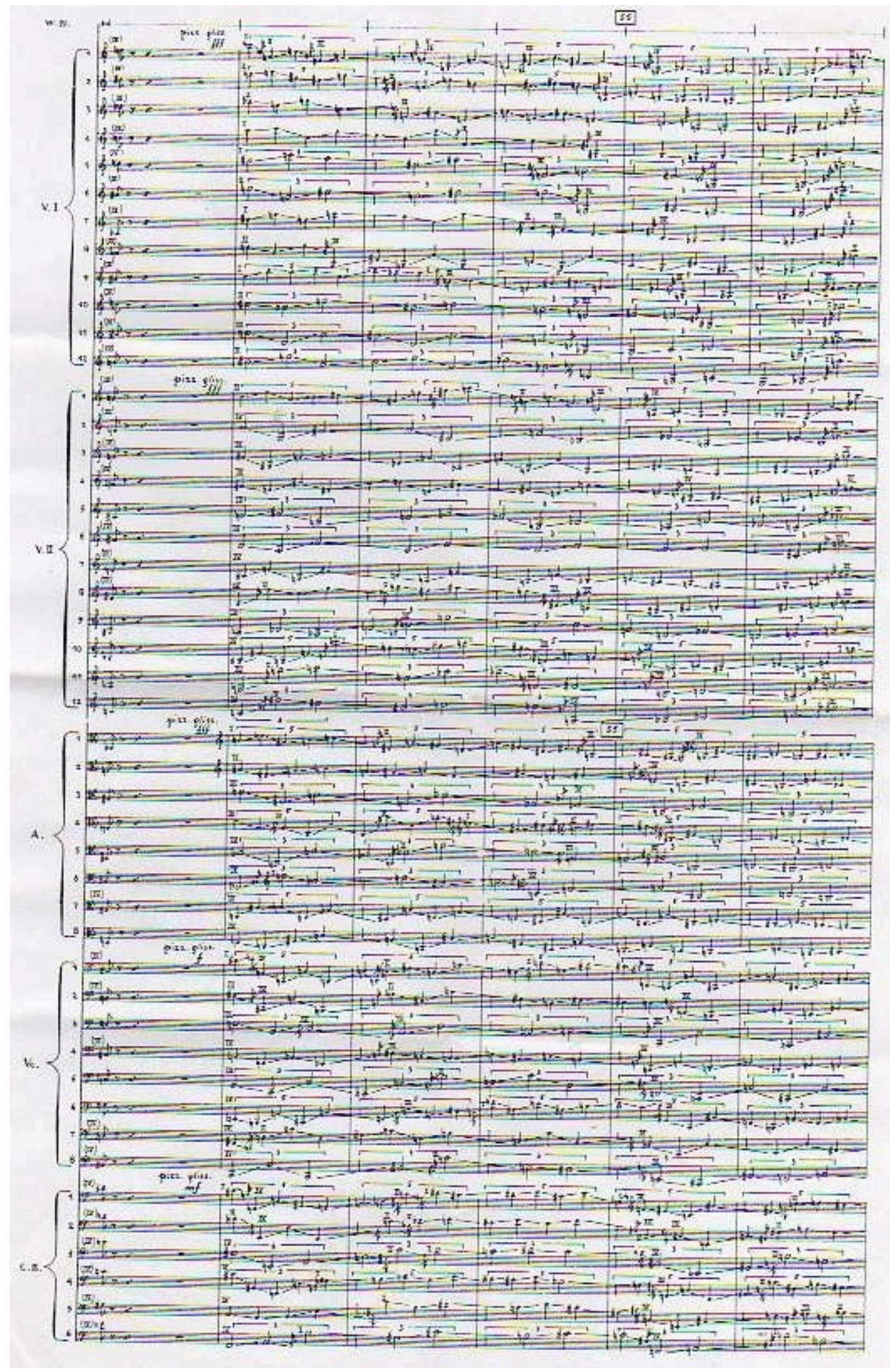

Fig 2.5 - Trecho da partitura de Pithoprakta correspondente aos compassos 52 a 57 (Xenakis, 1992:17) 
O compositor sugere que apenas nesta exata porção da peça, a abordagem matemática foi mais rigorosa. É necessário dizer que muito dos valores obtidos nos cálculos, como já dissemos antes, são sujeitos a aproximações de modo que o resultado sonoro não fosse comprometido. Dada a variedade, a fragmentação da peça, sua abordagem por partes e não para toda a obra levaram o compositor à necessidade de compor uma peça que fosse regida por um único princípio. Xenakis concluiu com Metastasis (1954) que a mobilidade no interior de uma massa sonora era possível; com Pithoprakta concluiu que a realização de cálculos, uma concepção matemática do sonoro também era possível. O passo seguinte foi a junção da busca estética que norteou essas duas composições, a realização de uma obra fundamentada num único princípio matemático, Achorripsis (1956).

\section{$\underline{2.4}$ Acerca da Linguagem}

Antes de nos dedicarmos à compreensão da peça Achorripsis (1956), convém compreendermos alguns pormenores da formalização dos parâmetros sonoros, de modo que o compositor pudesse inferir uma composição.

A arquitetura de uma peça estocástica foi concebida por Xenakis através de etapas sucessivas. Primeiramente surgem as concepções iniciais, intuições e dados definitivos ou provisórios, seguidos da definição das entidades sônicas, onde os eventos sonoros de diferentes características são concebidos e das possibilidades de emissão desses eventos sônicos através de instrumentos tradicionais ou eletroacústica. Definidas as entidades sônicas o passo seguinte é a definição das transformações dessas entidades ao longo da peça, grau de relacionamento dessas entidades seguindo um esquema lógico e matemático. Estabelecidas as entidades sônicas e suas transformações o compositor adentra o terreno da microcomposição que é a concepção detalhada de cada microcomponente. A totalidade da obra, a programação seqüencial de ocorrência das transformações microcompostas é então realizada. Seguem-se a implementação de cálculos, verificações, feedbacks e possíveis modificações visando o resultado sonoro final. Finalmente obtém-se o resultado simbólico que é a organização da obra em notação tradicional ou sua realização eletroacústica e sua definitiva realização sônica por meio de orquestras ou difusão eletroacústica. Xenakis ressalta que esse esquema não é um padrão rígido, algumas fases poderiam ser até mesmo 
omitidas, mas estabelece um encadeamento de idéias para a realização de suas composições.

A fase de definição das entidades sônicas estabelece uma representação vetorial $^{5}$ dessas entidades tendo em vista a clarificação do discurso e facilitando a elaboração das fases seguintes do esquema de composição. As entidades sônicas da orquestra clássica podem ser representadas portanto por um vetor com quatro variáveis independentes:

$$
\operatorname{Er}(\mathrm{c}, \mathrm{h}, \mathrm{g}, \mathrm{u}) \text { : }
$$

1- $\mathrm{ca}=$ timbre ou família instrumental

2- hi = altura do som

3- gj = intensidade do som ou forma dinâmica

4- $\mathrm{uk}=$ duração do som

O vetor Er define um ponto $\mathbf{M}$ na extensão temporal, provido por uma base $\mathbf{r}$ (c, $\mathrm{h}$, g, u). Esse ponto $\mathbf{M}$ conterá como coordenadas ca, hi, gj, uk. Por exemplo um violino executando arco, Dó na terceira oitava, em dinâmica forte e 240MM é representado da seguinte maneira:

c violino.arco, h39(=C3), g4(=forte), u5(1/4 seg.).

Um conjunto de pontos, um único ponto ou até mesmo nenhum ponto $\mathbf{M}$ são colocados no eixo que chamamos de Er. Esse eixo por sua vez é colocado num eixo t que representa sua localização exata na duração total da peça. Esse eixo chamado de eixo lexicográfico do tempo, representa a sucessão temporal dos pontos $\mathbf{M}$ do eixo Er.

Tal representação permite ao compositor passar para as fases de definição das transformações e microcomposição, regidas por um mínimo de regras. Os pontos $\mathbf{M}$

\footnotetext{
${ }^{5}$ Para mais informações acerca da formalização dos parâmetros sonoros reportamos o leitor ao capítulo sobre Música Simbólica.
} 
podem obedecer a uma lei aleatória sem memória permitindo uma distribuição estocástica de eventos nos eixos $(E r, t)$. Nesse caso uma certa distribuição probabilística regida por uma lei estocástica, cujas densidades não ultrapassem a capacidade de audição, caracteriza a realização de uma composição musical. A extração de um fragmento suficientemente longo de uma certa distribuição constitui uma peça musical e partindo desse princípio toda uma família de composições é possível com diferentes distribuições e densidades específicas.

\section{$\underline{2.5}$ Achorripsis}

A obra Achorripsis $^{6}$ de 1956, um ano após a realização de Pithoprakta, é a primeira tentativa de Xenakis de formalização de uma peça baseada num único princípio estocástico: a fórmula de Poisson. Ao contrário das peças anteriores concebidas para orquestras de maior porte, Achorripsis foi composta para um grupo instrumental de 21 instrumentos. Este grupo reduzido de instrumentos se comparados com as peças anteriores não omite o caráter massifico dos fenômenos sonoros. Xenakis submete uma única massa sonora de instrumentos a um processo meticuloso de distribuição dos eventos. Desse modo o compositor pensou a composição tendo em vista a escuta, sua capacidade de rastrear as nuances microscópicas de uma massa sonora, sua evolução no espaço-tempo onde a peça se projeta. A intenção do compositor era justamente a concepção de uma peça cuja complexidade probabilística fosse interessante para o ouvinte (Varga, 1996:79).

O espaço-tempo escolhido pelo compositor para a evolução dessa massa sonora, mais rarefeita, é uma matriz com 7 timbres distintos dispostos em linhas, a projeção espacial e 28 colunas que representam unidades discretas de tempo perfazendo um total de sete minutos, sua projeção temporal. A projeção espacial refere-se a emissão dos sons - os eventos sonoros - no espaço, como eles irão ocorrer, e a projeção temporal refere-se a decorrência temporal destes mesmos eventos, a duração dos eventos. As linhas de timbres que caracterizam as diferentes propriedades dessa massa evolutiva são flautas, oboés, metais, cordas em pizzicato, cordas em glissando e cordas em arco normal. As flautas são um piccolo, clarinete, e clarinete baixo; os oboés são um oboé baixo, um oboé contrabaixo e um oboé; os metais são dois trompetes e um trombone; a percussão tem um xilofone,

\footnotetext{
${ }^{6}$ Gravação - Achorripsis, EMI C063- 1001
} 
blocos de madeira e caixa baixo; as classes de pizzicato, glissandos e arco normal são três violinos, três violoncelos e três contrabaixos. Embora clarinetes não sejam flautas Xenakis os coloca arbitrariamente na classe das flautas. A duração da peça, sete minutos, escolhida pelo compositor a priori, foi dividida em 28 fatias temporais distintas, de duração igual a 15 segundos. $\mathrm{O}$ entrelaçamento das linhas de timbre com as fatias temporais define um espaço-tempo de 196 células. Como distribuir eventos sonoros de características distintas nesse espaço-tempo? A solução do compositor foi encontrada na fórmula de Poisson que será sucessivamente aplicada, primeiramente ao conjunto das 196 células, depois para as 28 colunas temporais e finalmente para as sete colunas de timbres. Dessa maneira a distribuição probabilística em acordo com a função de Poisson dará o tom fenomenológico da peça, a concatenação de um mecanismo criado artificialmente para nos dar a impressão do devir da natureza como fim estético.

Antes de passarmos diretamente à análise da estruturação da matriz devemos compreender uma concepção de densidade mais interior, pequenos glóbulos onde os parâmetros sonoros dos instrumentos irão agir diretamente. Estes glóbulos serão preenchidos após a finalização da estrutura matricial das probabilidades, no entanto, suas densidades particulares foram definidas previamente para que fossem distribuídos na matriz. Dada a duração da peça de 7 minutos, e a duração de 15 segundos para cada unidade, sendo estas aproximadamente 6.5 compassos em 26 MM (metrônomo Mälzel), Xenakis especificou cinco diferentes tipos de glóbulos de densidade: nulos, únicos, duplos, triplos e quádruplos. Os eventos únicos têm 5 sons por compasso, 2.2 sons por segundo e 32.5 sons por unidade; os eventos duplos têm 10 sons por compasso, 4.4 sons por segundo e 65 sons por unidade; os eventos triplos têm 15 sons por compasso, 6.6 sons por segundo e 97.5 sons por unidade; os quádruplos têm 20 sons por compasso, 8.8 sons por segundo e 130 sons por unidade; e os eventos nulos não contém nenhum som. Esses valores são limites mínimos. Por exemplo, se um evento tem 6.5 sons por compasso ele é um evento único e, a partir de 10 sons por compasso, ele passa a ser caracterizado como um evento duplo e assim respectivamente. Compreendidas as linhas de timbres, as colunas temporais, 
os glóbulos densos e o espaço total da matriz, passemos ao entendimento da elaboração da matriz em acordo com a função de Poisson? ${ }^{7}$.

Inicialmente, quando Xenakis compôs Achorripsis, as etapas descritas acima na formalização da linguagem eram calculadas manualmente, sendo um longo tempo despendido para criar uma única composição. A elaboração da matriz abaixo tinha que ser submetida a testes, aproximações de modo que não comprometessem a conseqüência sonora final.



algarismo em itálico - classes de timbres ( 1, 2, 3, 4, 5, 6, 7).

algarismo em negrito - unidades de tempo correspondentes a $15 \mathrm{~s}$, as vinte e oito colunas perfazem um total de sete minutos.

Fig 2.5 - Matriz da composição Achorripsis.

A fórmula de Poisson necessita de uma densidade $\lambda$ para ser calculada. Primeiramente $\lambda$ será especificada para o espaço-tempo total da matriz e posteriormente assumirá novos valores para as colunas temporais e para as linhas de timbre. O primeiro valor de $\lambda$ é 0.6 eventos por unidade do total de 196 células. Tendo em mãos o dado densidade o compositor recorre à aplicação da fórmula de Poisson,

$$
\mathrm{Pk}=\frac{\lambda^{k}}{K !} \mathrm{e}^{-\lambda}
$$

Onde $\lambda$ é a densidade já especificada, e é a base dos logaritmos naturais cujo valor aproximado é 2,718, e o símbolo “!” significa número fatorial que indica quantos

\footnotetext{
${ }^{7}$ Reportamos o leitor à introdução para uma compreensão intuitiva da distribuição de Poisson.
} 
modos uma coisa pode ser arranjada, seu número de permutações. A probabilidade $P$ indica a ocorrência de um evento e o índice $k$ identifica o evento.

São cinco tipos de eventos encontrados em Achorripsis: evento nulo, evento único, evento duplo, evento triplo e evento quádruplo - os glóbulos densos. Substituindo cada índice $k$ por números de 0 a 5 , que correspondem respectivamente aos eventos, o compositor obtém uma tabela de probabilidade de eventos. O índice 5 é descartado pois seu valor obtido na fórmula é muito pequeno para ser considerado estatisticamente relevante, e portanto os índices de 0 a 4 correspondem respectivamente aos glóbulos de eventos. Quanto maior o índice aplicado na fórmula menor é o valor obtido. O compositor então multiplica cada resultado obtido pela aplicação de um índice ( 0 a 4) a fórmula de Poisson pelo número de células da composição. Os resultados obtidos são 107 eventos nulos, 65 eventos únicos, 19 eventos duplos, 4 eventos triplos e 1 evento quádruplo perfazendo o total de 196.

Uma vez que cada probabilidade de ocorrência dos glóbulos densos foi calculada, Xenakis decide distribuir estas 196 células em 28 unidades discretas de tempo, que correspondem a um igual número de colunas.

Para calcular a distribuição de tipo de eventos por coluna, Xenakis reutiliza a fórmula de Poisson. Primeiramente ele obtém novos valores de densidade para cada densidade obtida anteriormente, referente ao total de células em que cada tipo de evento será distribuído $(107,65,19,4$ e 1). Obtidos estes novos valores de densidade, eles são então divididos por 28, o número de colunas. Deste modo uma seqüência de novos valores de $\lambda$ (densidades) é obtida, que serão novamente aplicados à fórmula de Poisson. Os índices $k$ da fórmula são tomados, desta vez de 0 a 7, sendo que após o sexto índice o valor obtido é muito pequeno para ser considerado relevante. Cada valor obtido dos índices de 0 a 6 na fórmula é então multiplicado pelo número 28 , de colunas. No caso dos eventos únicos a distribuição resultante é: 3 colunas não contém nenhum evento, 6 colunas contendo 1 evento, 8 colunas contendo 2 eventos, 5 colunas contendo 3 eventos únicos, 3 colunas contendo 4 eventos, 2 colunas contendo 5 eventos, 1 coluna contendo 6 eventos e 0 
coluna contendo 7 eventos. Totalizando o número de eventos únicos que é 65 agora distribuídos nas 28 colunas. Os índices $\mathrm{k}$ de 0 a 7 devem ser compreendidos como uma seqüência de freqüências de eventos por colunas, embora os valores após 6 serem extremamente pequenos, o compositor arredonda o valor do índice 6 para 1 e do índice 7 para 0.

A mesma aplicação utilizada para os eventos únicos também foi aplicada aos eventos nulos, duplos, triplos e quádruplos. Da mesma maneira os resultados obtidos são sempre aproximados tendo em vista uma conseqüência factível da perspectiva sonora.

Feita a distribuição por colunas, Xenakis distribui os eventos nas linhas que correspondem aos timbres. Novamente a fórmula de Poisson é aplicada. O procedimento é semelhante ao anterior. Um novo número de densidade é estabelecido para cada quantidade de eventos $(107,65,19,4$ e 1) desta vez tomando como base o número de linhas, isto é, dividindo cada número por 7. Obtidos os valores de densidades aplica-se novamente a fórmula de Poisson. No caso das linhas, os valores de densidades obtidos são ainda menores que aqueles obtidos para as colunas, Xenakis lança mão de todo tipo de recurso para não comprometer o objetivo estético da composição. A configuração da matriz cabe somente ao compositor, tendo em mãos as respectivas quantidades de distribuição, agindo ludicamente sobre a matriz. É como se Xenakis inventasse uma brincadeira de probabilidades sônicas, designando ele mesmo: o tamanho do tabuleiro, a quantidade de peças, como elas se movimentarão, enfim, as regras do jogo, que tem como princípio a fórmula de Poisson.

A matriz da peça em acordo com a distribuição de eventos ficou da seguinte maneira:

\begin{tabular}{|c|c|c|c|c|c|c|c|c|c|c|c|c|c|c|c|c|c|c|c|c|c|c|}
\hline Coluna & 1 & 23 & 45 & 67 & 89 & 10 & 111 & $\begin{array}{ll}12 & 1\end{array}$ & 1312 & 1415 & $\begin{array}{ll}5 & 1\end{array}$ & & 17 & 181 & & 202 & 122 & 23 & 24 & 25 & 26 & 2728 \\
\hline Linha I & & $\mathrm{UU}$ & $\mathrm{D} D$ & & U & & & & & & & $\bar{D}$ & $\overline{\mathrm{U}}$ & U & U & U & $\bar{U}$ & $\mathrm{U}$ & & $\mathrm{U}$ & & $\mathrm{U} \mathrm{D}$ \\
\hline Linha II & & & & $\mathrm{U} U$ & $\mathrm{U}$ & $\mathrm{U}$ & & & U & & U & & & U & & & U & & & Q & & U \\
\hline Linha III & & U & & U & U & $\mathrm{J}$ & & & $\mathrm{T}$ & & $U \quad \mathrm{U}$ & U & $\mathrm{U}$ & & & D & U & & & & $\mathrm{U}$ & U \\
\hline Linha IV & & $\mathrm{D}$ & D & $\mathrm{D}$ & & U & U & $\mathrm{U}$ & & & & & D & U & $\mathrm{U}$ & U & & & & $\mathrm{D}$ & $\mathrm{U}$ & \\
\hline Linha V & $\mathrm{U}$ & U U & & U U U & $\mathrm{U}$ & $\mathrm{J}$ & & & $\mathrm{U}$ & & & U & U & U & & & $\mathrm{T} \quad \mathrm{D}$ & $\mathrm{D}$ & & U & & \\
\hline Linha VI & & & & D & $\mathrm{U}$ & $\mathrm{J}$ & D & & & U & & & & U & U & U & & & & $\mathrm{D}$ & & $\mathrm{U}$ \\
\hline Linha VII & & & U T & U & & D & U & & D & & & & U & $\mathrm{U}$ & U & $\mathrm{U}$ & & & & D & U & $\mathrm{T}$ \\
\hline
\end{tabular}

Branco=Evento Nulo; U=Evento Único; D=Evento Duplo; T=Evento Triplo; Q=Evento Quádruplo. 
Fig 2.6 - Outra representação da matriz de Achorripsis.

De acordo com a tabela de distribuição de eventos, verificamos que a coluna 17 inclui nas linhas I, III, V e VII eventos únicos, na linha IV evento duplo e nas linhas II e VI eventos nulos. A coluna 17 indica que os timbres correspondentes às linhas II e VI, oboés e metais respectivamente, estarão em silêncio, oboés e metais não soarão. Como vimos inicialmente os valores de densidade especificados para os glóbulos densos são limites, valores que podem ou não ser alcançados em sua totalidade. Embora as linhas I, III, V e VII contenham eventos únicos, elas têm densidades específicas em acordo com o limite para evento único que verificamos no início. Isso significa que tendo em mãos o limite de densidade Xenakis o utiliza arbitrariamente. Como o limite mínimo para evento único é igual a 5 sons por compasso, Xenakis decide que os eventos únicos nas linhas I (flautas) e VII (cordas em arco) terão 5 sons por segundo, a linha III (cordas em glissando) terá 4.5 sons por compasso, e a linha $\mathrm{V}$ terá 5.5 sons por compasso. $\mathrm{O}$ evento duplo tem um limite mínimo de 10 sons por compasso especificado para a linha VI (percussão) (Xenakis, 1996: 28). O exemplo a seguir corresponde aos compassos 104 a 111 da partitura de Achorripsis, corresponde a coluna 17 da tabela de distribuição de eventos acima. 


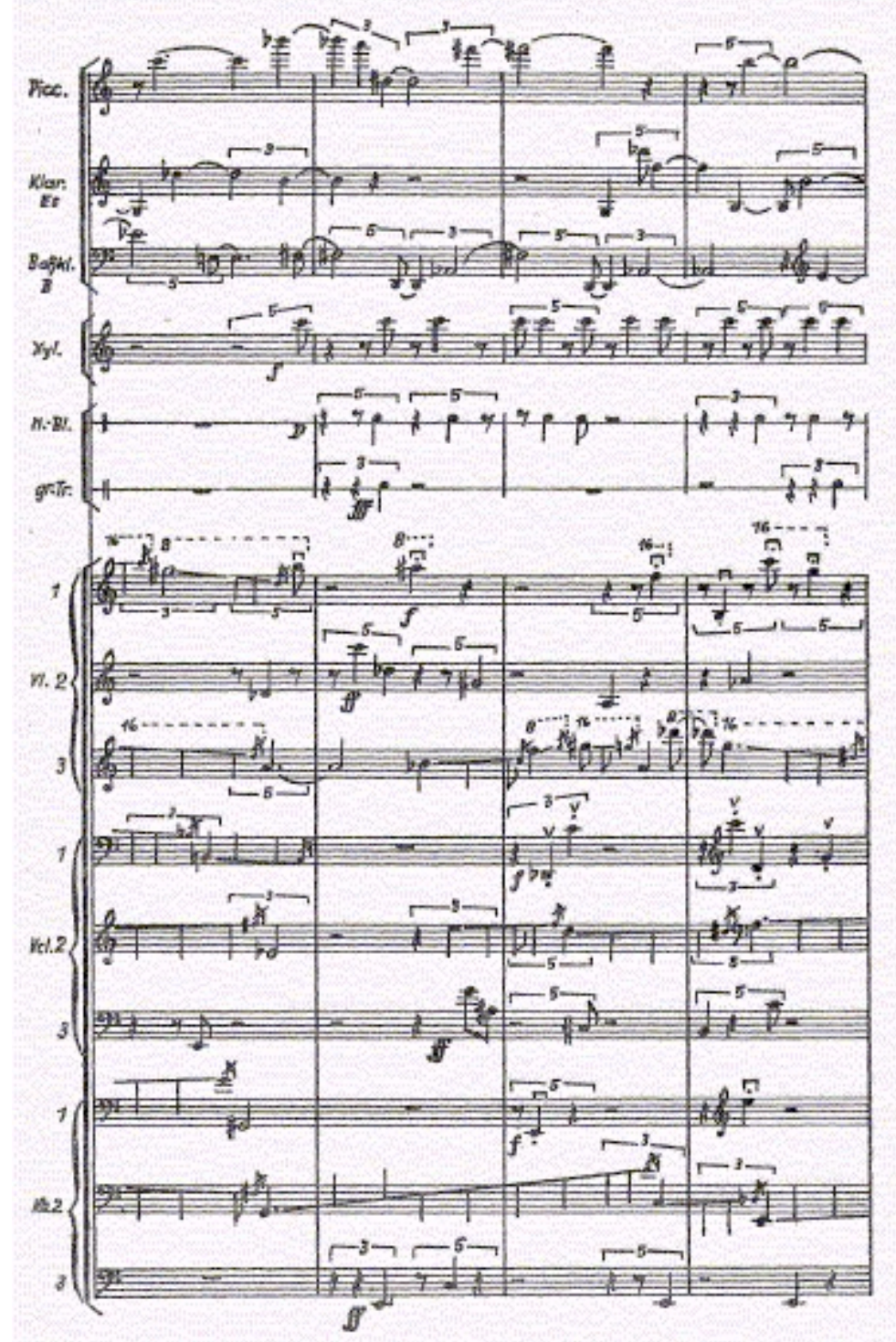




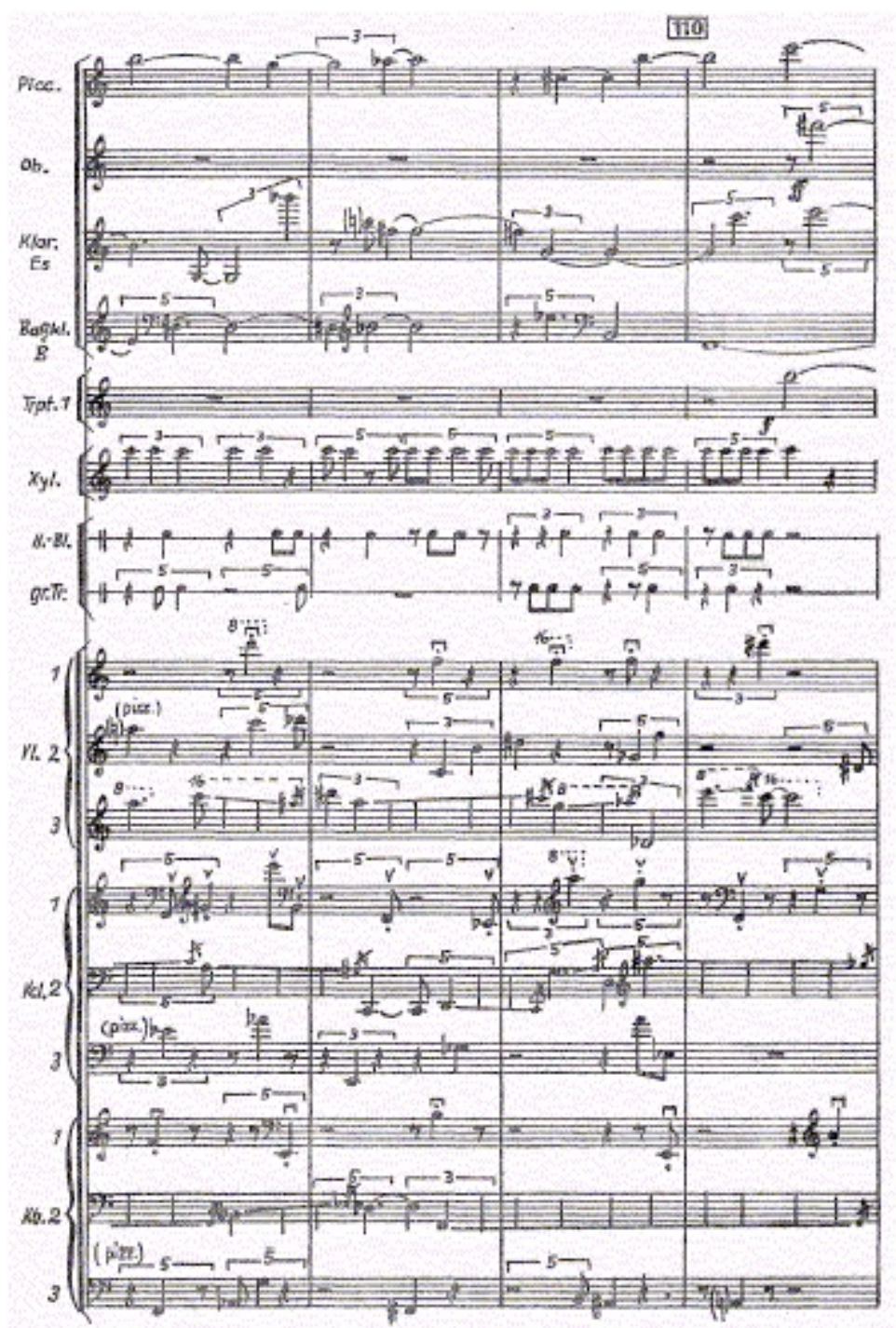

Fig.2.7 - Compassos 104-111 de Achorripsis (Xenakis, 1996: 26-27).

Podemos notar que na segunda metade do compasso 110 há uma nota para oboé e uma nota para trompete, mas esta já faz parte da coluna seguinte, a coluna 18 e não mais à coluna 17.

No caso da microcomposição da obra, ou seja, de como seriam especificadas as notas de cada timbre no interior de cada glóbulo denso, Xenakis oferece como exemplo apenas aquele dos glissandos. O tratamento dos glissandos é semelhante ao procedimento dos glissandos na peça Pithoprakta, utilizando para isso a distribuição de Gauss. No caso dos demais timbres o compositor não oferece uma explicação de como foram realizados, sugerindo que foram especificados de acordo com leis de probabilidade. 


\section{$\underline{2.6 \text { As Pecas ST }}$}

As peças ST surgiram alguns anos após a realização de Achorripsis, quando Xenakis teve acesso a computadores IBM - 7090 em linguagem Fortran ${ }^{8}$.

A realização de peças estocásticas por computador, daí o nome ST, abreviação da palavra estocástica, segue os mesmos procedimentos que foram utilizados em Achorripsis com a vantagem da automatização de todo o processo através de uma algoritmo.

Xenakis oferece seis razões para a utilização de computadores em composição musical:

1. O pensamento criativo do homem dá nascimento a mecanismos que, em última análise, são meramente conjuntos de regras e escolhas. Este processo tem lugar em todos os campos do pensamento, incluindo as artes;

2. Alguns desses mecanismos podem ser expressados em termos matemáticos;

3. Alguns deles são fisicamente realizáveis: aviação, motores, bombas, computadores digitais, computadores analógicos, etc;

4. Certos mecanismos mentais podem corresponder a certos mecanismos da natureza;

5. Certos aspectos da criação podem ser simulados por certos mecanismos físicos ou máquinas que existem ou podem ser criadas;

6. Acontece que computadores podem ser úteis de certo modo (Xenakis, 1992: 132-133).

No início da década de 1960 Xenakis compôs uma peça gerada por dados de computadores: ST/10 - 080262. O número 10 é o número de classes de instrumentos, sendo que percussão é contada como uma única classe, e o número “080262” refere-se à data da peça quando gerada pelo computador, 8 de Fevereiro de 1962.

\footnotetext{
${ }^{8}$ A linguagem de programação FORTRAN foi uma das linguagens de alto nível em meados dos anos 1960, não era uma linguagem específica de máquina, e apresentava grande portabilidade, isto é, era facilmente compatível com outros computadores (Chadabe, 1997:112).
} 
$\mathrm{O}$ algoritmo programado por Xenakis em linguagem Fortran tem os seguintes passos: a) A peça consiste de uma sucessão de seqüências ou movimentos com $a i$ segundos de duração; c) definição da densidade média de sons durante $a i$; c) composição $Q$ da orquestra durante a seqüência $a i$; d) definição do momento de ocorrência do som $N$ na seqüência $a i$; e) Atribuição de um instrumento pertencente à orquestra $Q$, já calculada para o som acima; f) Atribuição de uma altura como uma função do instrumento; g) Atribuição de uma velocidade glissando se a classe $r$ de instrumentos é caracterizada como um glissando; h) atribuição de uma duração $x$ aos sons emitidos; j) As mesmas operações são reiniciadas para cada som do cluster Nai; e 1) recálculos do mesmo gênero são feitos para outras seqüências.

O conjunto de peças geradas pelo programa ST tem o mesmo princípio daquele de Achorripsis (1956), a distribuição estocástica baseada na fórmula de Poisson. A diferença substancial é que todos os passos seguidos em Achorripsis são automatizados através do programa ST concebido por Xenakis. A informatização dos procedimentos através dos passos acima, conseqüentemente, agiliza a geração de peças. $\mathrm{O}$ controle dos parâmetros sonoros são trabalhados no interior do programa, ou seja, são os dados de entrada. A confecção de uma peça estocástica por computador consiste na designação dos dados de entrada para diferentes parâmetros sonoros: unidade de tempo, conjunto de instrumentos, densidades, etc. Caso os dados de entrada ocasionem erros de cálculo, o compositor pode voltar aos passos iniciais e especificar novas entradas. Portanto, a introdução de parâmetros a esmo não garante uma peça como produto final, esta deve necessariamente ser realizada somente se conhecido o funcionamento do algoritmo.

Não se deve pensar que a utilização de um programa de computador forneça como resultado final a partitura pronta para execução. O computador oferece uma lista de dados que então será transcrita para notação tradicional. Neste processo de transcrição de uma linguagem de dados para outra são necessárias escolhas de caráter compositivo para assegurar o resultado sonoro almejado pelo compositor.

De acordo com os passos vistos acima o programa ST providencia uma lista de parâmetros tais como tempo de ataque, classe de instrumento, instrumento (isto é, seleção de instrumentos numa dada classe, e a técnica de execução, altura, duração, dinâmica e três 
parâmetros para glissandos). Esta lista de representação dos parâmetros facilita a transcrição para a partitura - a notação tradicional - conseqüente (Keller, Ferneyhough: 2004, 162).
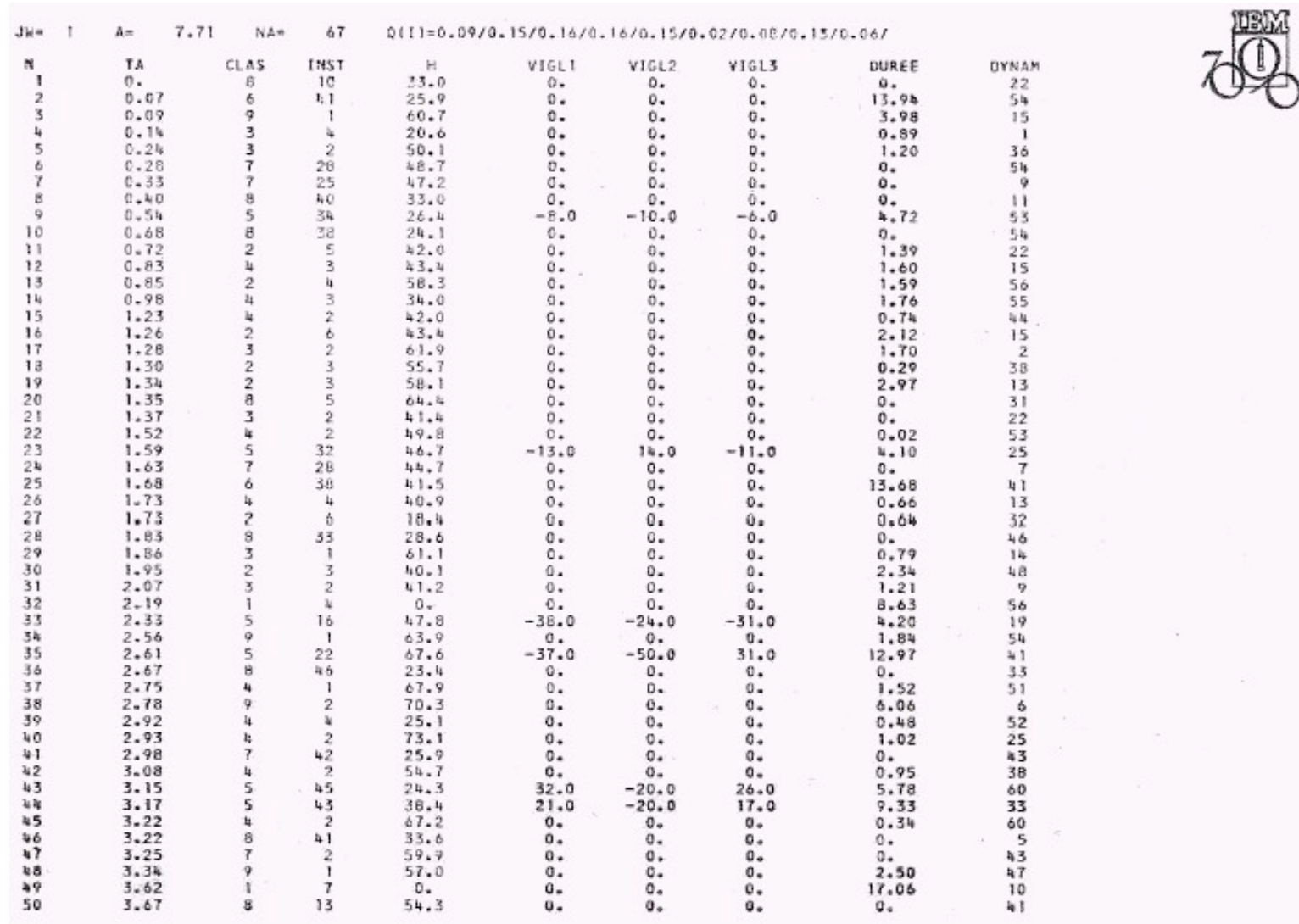

Fig. 2.8 - Exemplo de lista de parâmetros obtida para a realização de transcrição em partitura (Xenakis: 1962).

\subsection{A Música Estocástica:Perspectiva Perceptiva}

Da realização de Metastasis (1954) à realização das peças ST há uma evolução sensível em direção à abstração musical, com base no universo físico e matemático. Ao acompanhar esta evolução nos deparamos com o esforço de Xenakis em revelar, ressignificar, e propor novos mundos sonoros. Ao forçar no sonoro coisas que a priori não são sonoras, o compositor grego, como num estalo, num volteio, vai à matemática platonicamente, a contempla e, como um gaiato, dá um salto para fora, causando um choque estético. Que choque é esse? O choque de um campo do conhecimento, a 
matemática encerrada em si mesma, que num rompante brutal julga absolutamente todo o sonoro. Ser e pensar em versão audível, coisa perene do mundo, expansão licenciosa do ser que passa a incluir o não ser, matéria encontra antimatéria, o contemplado violentamente percebido. A música de Xenakis experimenta o mundo eliminando do belo qualquer reminiscência divina, acaso como possibilidade única do espaço-tempo, vivido e idealizado.

Os primeiros instantes de Metastasis (1954), equiparáveis a seus instantes finais, uma massa de glissandos, carrega em seu interior a verdade primordial da seção áurea, dos números de Fibonnacci. Esta mônada de entrelaçados se desdobra e a escuta desfia. De fato, não conta o tecido polifônico nem suas características harmônicas, mas chama a escuta ao rastreamento de aglomerações e espargimentos dos eventos sonoros desenrolados. Essa massa de glissandos que tornou Xenakis conhecido, além de apresentar-se como novo princípio formal só é possível em conjunção com aquilo que se espera da escuta. Uma escuta que também é capaz de atentar-se a outras realidades do sonoro, extrapolando as possibilidades estritas exigidas pela tradição musical. No entanto, quando Xenakis propõe novo princípio formal para uma nova escuta, não o faz numa tentativa de subjugar a tradição, como se nela houvesse erro. Para ele a tradição não é campo de batalha, é possibilidade já explorada. Metastasis é também o início de um vasculhar da escuta inexplorada, tonitruante derradeiro.

A porção gasosa de Pithoprakta (1955), breve instante cinemático, abrupto, é contundente no estreitamento da ligação entre ciência e música. Esse trecho de Pithoprakta levanta o seguinte questionamento: é a música que permite escutar a ciência ou vice-versa? ou ambas são indissolúveis? Por exemplo, quando olhamos para o céu e prestamos atenção à formação, transformação e movimentação das nuvens, somos capazes de observar suas propriedades macroscópicas guiadas por grandezas microscópicas - moléculas de água. A observação das nuvens não significa que enxergamos ciência, mas cônscios de uma teoria científica que explica as nuvens - a teoria cinética dos gases - certamente torna o fenômeno passível de intensa acuidade. A tentativa de Xenakis é propor uma escuta semelhante à visão das nuvens, capaz de perceber a dimensão gasosa, densa, da fenomenologia sonora. O desfilar de pontos glissantes de Pithoprakta desvela novos campos perceptivos permitidos 
pela escuta. No entanto, uma intenção de escuta é necessária, ou seja, o conhecimento do princípio que ordena o material sonoro. $\mathrm{O}$ alvo estético só é atingido quando converge na escuta a apreensão, ao menos intuitiva, do princípio ordenador.

A peça seguinte de 1956, Achorripsis, une a abordagem massifica de Metastasis com a abordagem gasosa de Pithoprakta, submetida ao único princípio que rege toda a peça e não apenas trechos: uma distribuição estocástica baseada na fórmula de Poisson. É possível escutar a fórmula de Poisson? Não, a escuta de Achorripsis revela primeiramente densidades não tão cheias como em Metastasis e momentos gasosos como os de Pithoprakta. No interior de Achorripsis podemos perceber eventos sonoros, glóbulos gasosos distintos (timbres), densidades díspares correndo independentes umas das outras ao longo de sua ocorrência temporal, mas que obedecem um único princípio probabilístico. Achorripsis é como se fosse um universo sonoro único, cuja diversidade de seres, objetos sonoros distintos interagem, confrontam-se, permitem a si mesmos simultaneidades e disparidades num espaço-tempo próprio, hermético. Não seria correto a escuta buscar a apreensão de uma unidade coesa e coerente, como aquela que se apresenta na matriz concebida para a confecção de Achorripsis. A escuta deve se reportar a Achorripsis como se esta fosse um recorte da evolução de um organismo vivo. A entrega da consciência, por intermédio da escuta, à apreensão estética de instantes macroscópicos e microscópicos das partículas sonoras.

Como já dissemos, as peças $S T$ utilizam o mesmo procedimento de Achorripsis para a criação musical com a vantagem da informatização do processo através de computador. Desta maneira uma infinidade de universos sonoros são possibilitados para formações instrumentais distintas, temporalidades diversas, enfim, todo um conjunto de peças com diferentes complexidades internas. Uma das peças do conjunto ST, $S T / 4^{9}$ para quarteto de cordas, apesar de obedecer princípios semelhantes àqueles designados para Achorripsis, soa como um organismo cuja complexidade interna é imanente. As quatro linhas de timbres de um quarteto de cordas, a despeito de pertencerem à mesma família de instrumentos, atuam como entidades próprias de um mesmo organismo, no interior de uma única macroforma. A geração de peças por meio de um mesmo programa computacional poderia

\footnotetext{
${ }^{9}$ Gravação - Xenakis Chamber Music - 1955-1990, Arditti String Quartet, selo Montaigne näive.
} 
sugerir a idéia de redundância, previsibilidade, refletida no conjunto de peças criadas. Xenakis rebate a sugestão afirmando que

“... previsibilidade é uma coisa muito relativa. Quando você ouve música que não conhece, lhe parece que é tudo a mesma coisa. Entretanto, você pode prever o que vai acontecer. Mas, de fato, você não prevê algo que não está muito claro em sua mente. Após a repetição de muitas audições você começa a conhecer melhor a peça. Depois você é absorvido por coisas que reconhece e coisas que parecem inesperadas. Então a composição pode ser imprevisível quando considera os detalhes que ainda não tenha prestado atenção." (Xenakis apud Zaplitny, 1975:95).

Concluímos que na música estocástica de Xenakis há sempre algo novo a ser revelado à escuta mesmo após repetidas audições. Não há somente uma perspectiva auditiva com relação à música probabilística do compositor grego, como música das possibilidades podemos nos permitir inúmeras escutas prováveis. 


\section{MÚSICA ESTOCÁSTICA MARKOVIANA}

Antes de entrarmos no terreno da música estocástica markoviana, convém primeiramente lançarmos um olhar para duas peças eletroacústicas de Xenakis. Compostas no final da década de 1950, são decisivas para a compreensão da abordagem granular que realizaria nas peças Analogique A e Analogique B, as peças emblemáticas de música estocástica markoviana.

\section{$\underline{3.1 \text { A Música Concreta de Xenakis }}$}

No mesmo ano de composição da peça Metastasis, 1954, Xenakis foi aceito no Group de recherches de musique concrete (renomeado de Groupe de recherches musicales em 1958, atualmente conhecido como GRM). A intenção do compositor destoava do caráter do grupo no período, pois desejava efetuar o estudo da evolução de timbres, dinâmicas registros e combinação de ataques de timbres (Harley, 2002: 35). Suas duas peças iniciais neste grupo, Diamorphoses e Concret PH, fazem jus a sua abordagem de massas sonoras e indicariam os rumos que tomaria no futuro quando rompe com essa estética. Xenakis rompe com a estética concreta quando compõe Analogique B, cujo material são pequenos sons senoidais, embora tratados concretamente como veremos adiante. Segue uma pequena análise de cada uma dessas peças composta no GRM.

Em 1957, o compositor conclui sua primeira peça concreta Diamorphoses, demonstrando a intenção do compositor em criar peças com texturas de densidades diversas de ruídos, destoando do plano geral de composições do grupo naquele período (Harley 2001:35).

A peça apresenta timbres ruidosos em baixa frequência e timbres com maior definição em alta frequência. Os primeiros foram extraídos de um tremor de terra, de um motor de propulsão à jato e de um trem. Os outros foram extraídos de sinos. O glissando natural do jato foi combinado com o glissando de outros sons através de manipulação de fita magnética em estúdio. A peça é trabalhada de forma a não evidenciar a fonte primária da qual os sons foram extraídos e manipulados. Tal característica, inédita no meio da 
abordagem musical concreta, seria verificada em todos os outros trabalhos eletroacústicos posteriores de Xenakis, tais como Concret Ph e Analogique B.

A organização formal da peça é um tanto simples. As duas seções de sons de característica contínua como os ruídos em camadas e os glissandos foram contrastados com uma textura central preenchida com mudanças de timbre variadas, primeiramente com os sons de sino e depois com a adição de outros. Os ataques discretos foram definidos com a ajuda de cálculos de probabilidades.

A peça concreta CONCRET PH (1958), a despeito de seus poucos 2 minutos e 45 segundos, é uma longa textura, intrincada e complexa. Primeiramente sons de pedaços de carvão quebrando e queimando foram gravados em fita magnética, estabelecendo o material bruto da peça, que seriam então manipulados. Pequenos trechos foram extraídos e isolados do contexto original. Cada trecho corresponde a um estalo de carvão sendo consumado ou estilhaçado. Esses ruídos explosivos têm duração de centésimos e até mesmo milésimos de segundo. Após a gravação e a seleção do material, os curtos ruídos explosivos foram agrupados em camadas para compor uma longa textura. Essa malha quebradiça é muito semelhante à porção central de Pithropakta (1956), sua segunda peça orquestral (Harley, 2002: 37). A utilização de cálculos na peça é controversa. Estudos como o de Di Scipio, enfatizam a utilizaação de cálculos (Di Scipio, 1998: 204), já Roads afirma que a peça não é resultado de operações matemáticas, mas abordada pelo compositor intuitivamente (Roads, 2001: 65).

\section{$\underline{3.2}$ A Música Estocástica Markoviana}

A concepção da Música Estocástica Markoviana no início da década de 1960 é o segundo estágio do desenvolvimento da Música Estocástica, primeiramente "livre" onde diferentes tipos de distribuições fundamentadas na probabilidade matemática foram utilizados. Aqui as distribuições probabilísticas abordadas anteriormente como Poisson e Linear, notavelmente na composição de 1956, Achorripsis, serão novamente utilizadas. Como veremos, o papel dessas distribuições não serão menores, mas como, anteriormente, 
utilizadas com a função de especificar o conjunto de frequências, intensidades e densidades de uma massa sonora. $\mathrm{O}$ importante nesse estágio é que o compositor grego aborda num primeiro momento uma nova teoria acústica de meados do século $\mathrm{XX}$, os "sinais de Gabor" e num segundo momento as "cadeias de Markov", um processo de encadeamento probabilístico.

A teoria de Música Estocástica Markoviana foi aplicada nas peças Analogique $A \mathrm{e}$ Analogique $B$, compostas entre 1958 e 59 . Ambas são de natureza análoga nos aspectos formais mas utilizando materiais de universos distintos, sendo Analogique A para orquestra de cordas e Analogique $B$ composta a partir da geração de sons senoidais gravados e manipulados em fita magnética. Embora sejam composições distintas, existe a possibilidade de serem executadas em sincronia gerando uma outra peça denominada Analogique $A+B$. A peça Analogique $B$ marca também o rompimento de Xenakis na utilização de técnicas puramente concretas em suas composições eletroacústicas, como é o caso de Concret $\mathrm{PH}$ e Diamorphoses.

Primeiramente analisaremos as teorias dos Sinais de Gabor e as Cadeias de Markov para em seguida compreendermos suas aplicações musicais realizadas por Xenakis.

\subsubsection{Teoria de Gabor}

O físico britânico Dennis Gabor propôs uma nova teoria acústica em meados da década de 50. Numa série de três textos fundamentados na física quântica e em experimentos práticos, Gabor propõe que qualquer som pode ser considerado uma sucessão de unidades discretas de energia acústica, ou seja qualquer som pode ser decomposto em uma família de funções obtidas pela mudança de tempo e frequência de uma única partícula gaussiana (isto é, cujo envelope é em formato de sino). Isso quer dizer que qualquer som pode ser decomposto em milhares de grãos. (Roads 2001: 57).

A teoria de Gabor envolve dois parâmetros acústicos anteriormente não relacionados: tempo e frequência. O som quântico, o grão sonoro, é representado matematicamente relacionando um sinal no domínio do tempo $\mathrm{s}(\mathrm{t})$ a um espectro no domínio da frequência $\mathrm{S}(\mathrm{f})$. Ao mapear uma função de energia de um sinal s(t) acerca de uma certa duração _t 
numa função de energia de S(f) acerca de uma certa extensão de frequência $f$ obtém- se o grão sonoro. Os quanta de Gabor são portanto unidades elementares de informação acústica e podem ser representados com oscilações em qualquer frequência audível $f$, modulados por uma envoltória de duração finita como uma curva Gaussiana. A fórmula para os grãos sonoros é a seguinte:

$$
\begin{aligned}
& \mathrm{g}(\mathrm{t})=\mathrm{e}^{-a^{2(t-t 0)^{2}}} \times \mathrm{e}^{2 \pi j f 0 t} \\
& -\mathrm{t}=\pi^{1 / 2} / \mathrm{a} \mathrm{e}_{-} \mathrm{f}=\mathrm{a} / \pi^{1 / 2}
\end{aligned}
$$

Onde a primeira parte define o envelope Gaussiano e a segunda define a função senoidal complexa (frequência mais fase inicial em cada grão sonoro). O parâmetro $a$ é uma constante que relaciona a duração do grão à freqüência. A geometria desse grão depende de $a$, portanto quanto maior o valor de $a$ maior a resolução do tempo gasto na resolução da frequência. (Roads 2001:58-59)

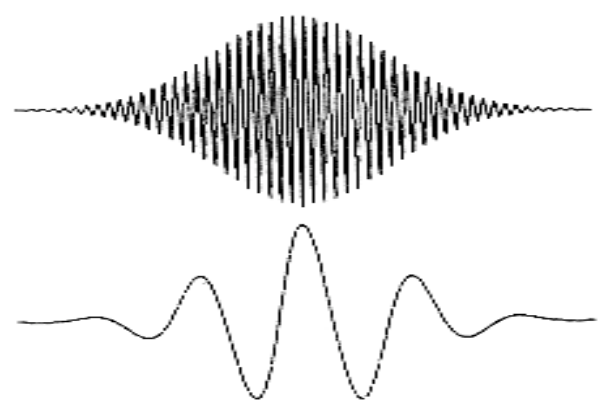

Fig 3.1 - gráfico de um sinal de gabor.

\subsubsection{Cadeias de Markov}

Uma Cadeia de Markov ${ }^{l}$ pode ser definida da seguinte maneira: considere uma variável aleatória $\boldsymbol{x t}$ assuma valores inteiros e t os valores $0,1,2,3, \ldots$ discreta e assumindo os seguintes valores $\mathrm{n} 0, \mathrm{n} 1, \mathrm{n} 2, \ldots, \mathrm{n} l$. Um processo probabilístico fica completamente definido até o instante $l$ pela distribuição conjunta: $\mathbf{P} \boldsymbol{l}(\mathrm{n} 0, \mathrm{n} 1, \mathrm{n} 2, \ldots, \mathrm{n} 1)$ de que $\boldsymbol{x} \boldsymbol{t}$ tome o valor $n 0$ no instante $t=0$, e assim por diante, até $\mathrm{n} l$ no instante $t=l$. Considere a probabilidade condicional $\mathbf{P} \boldsymbol{l}+\mathbf{1}(\mathrm{nl}+1 \mid \mathrm{n} 0, \mathrm{n} 1, \mathrm{n} 2, \ldots, \mathrm{nl})$ de que a variável $x t$ tome o valor

\footnotetext{
${ }^{1}$ Reportamos o leitor à introdução desta dissertação para mais detalhes acerca das Cadeias de Markov.
} 
$n l+1$ no instante $t=l+1$, dado que ela tenha tomado o valor $n 0$ no instante $t=0$, o valor $n 2$ no instante $t=2, \ldots$, e o valor $n l$ no instante $\mathrm{t}=1$. Se ela for igual à probabilidade condicional $\mathrm{Pl}+1(\mathrm{nl}+1 \mid \mathrm{nl})$ de que a variável $\boldsymbol{x t}$ tome o valor $\mathrm{n} l+1$ no instante $\mathrm{t}=1+1$, dado que ela tenha tomado o valor $\mathrm{nl}$ no instante $\mathrm{t}=1$, o processo é então um processo markoviano. Desta maneira podemos entender um processo markoviano em que a probabilidade condicional $\boldsymbol{x t}$ tomar um determinado valor num determinado instante depende somente do valor que ela tenha tomado no instante anterior. (Tomé e Oliveira, 2001: 81-82)

\subsection{Construcão dos Eventos Sonoros}

Xenakis elabora toda uma estética musical a partir da Teoria de Gabor, utilizando milhares de grãos sonoros para criar massas sonoras de características distintas e as Cadeias de Markov para criar a evolução dessas massas ao longo do tempo. O compositor nos oferece a seguinte imagem acerca de sua estética:

\footnotetext{
"Um som complexo pode ser imaginado como um fogo multicolorido em que cada ponto de luz aparece e instantaneamente desaparece contra um céu escuro. Mas nesse fogo poderia haver uma tal quantidade de pontos de luz organizados de tal modo que sua rápida e prolífica sucessão poderia criar forma e espirais, desdobrando-se vagarosamente ou inversamente, breves explosões num céu flamejante. Uma linha de luz poderia ser criada por uma multitude suficientemente grande de pontos aparecendo e desaparecendo instantaneamente" (Xenakis 1992: 44).
}

Dessa maneira o compositor cria o conceito de Tela, uma representação gráfica onde os parâmetros frequência _F, amplitude _G, densidade _D e duração _T serão especificados e o conjunto da sequência de telas irão descrever um som complexo, um determinado evento sonoro. O compositor irá trabalhar com unidades de tempo suficientemente pequenas e invariáveis permitindo mobilidade apenas nos parâmetros de frequência, intensidade e densidade. Ao longo da duração de um evento sonoro, podemos encontrar na sequência de telas, uma tela não preenchida com grãos, bem como uma totalmente preenchida (ruído branco). Os exemplos gráficos abaixo provêem uma noção visual da construção de telas. 


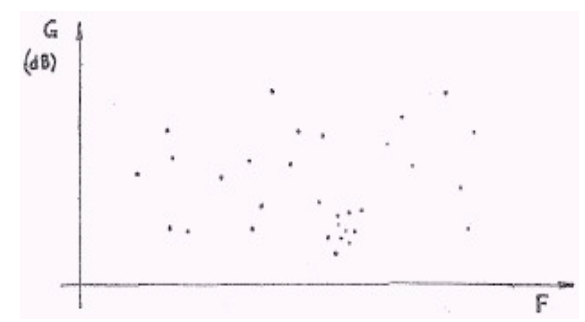

Fig 3.2 - O gráfico aponta uma coleção de grãos sonoros sobre o eixo G (intensidade) e F (freqüência) (Xenakis, 1992).

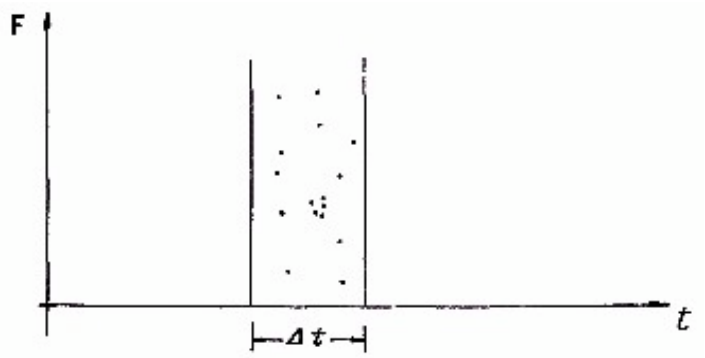

Fig 3.3 - Grãos sonoros dispostos numa única fatia de tempo _t.

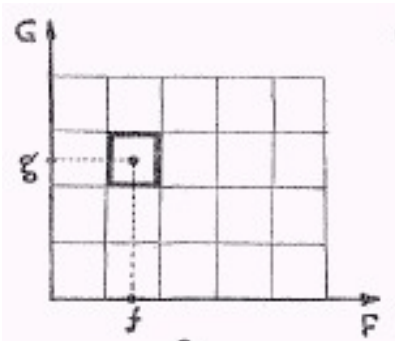

$\underline{2}$

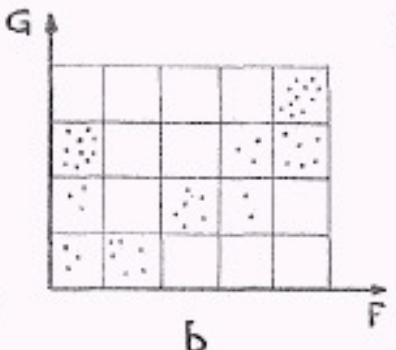

$\underline{b}$

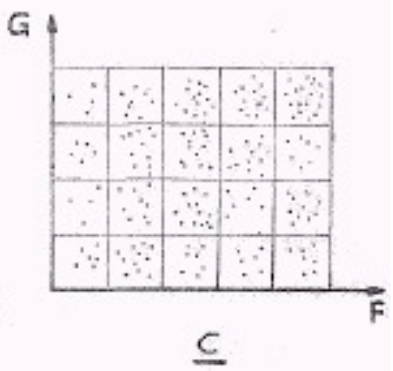

$\underline{\subseteq}$

Fig 3.4 - Três telas com diferentes disposições nos eixos G (intensidade) e F (freqüência). A primeira tela à esquerda (a) representa somente um grão de freqüência e intensidade únicas. A tela central (b) representa uma coleção de grão de intensidades e freqüências distintas. A tela à esquerda (c) é como um ruído branco com grãos localizados em todas as regiões de intensidade e freqüência (Xenakis, 1992). 


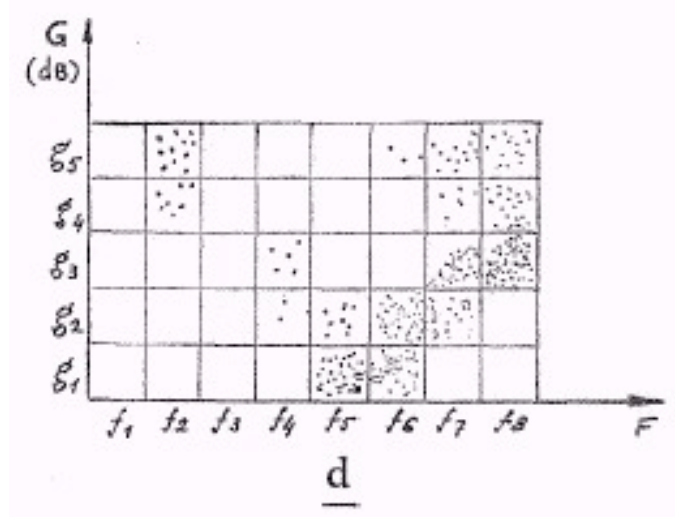

Fig 3.5 - A tela (d) representa uma coleção de grãos devidamente localizados em cinco regiões distintas de intensidade e oito regiões distintas de freqüência (Xenakis, 1992).

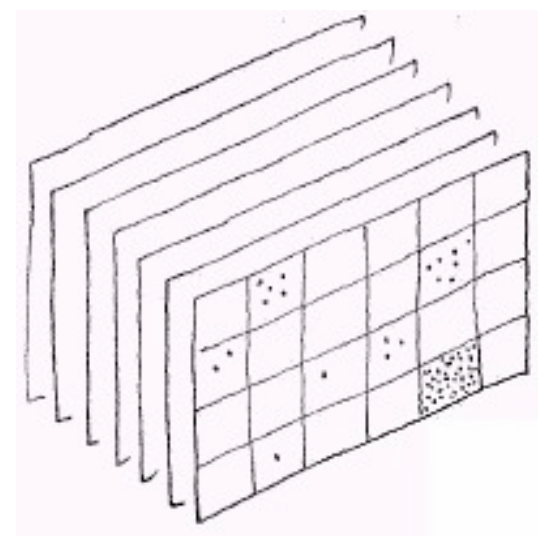

Fig 3.5 - Uma coleção de telas como a que vimos acima descreve um som complexo que evolui numa certa duração.

Os cálculos para o elemento _T, duração, são feitos através distribuição exponencial:

$$
\operatorname{Px}=\delta \mathrm{e}^{-\delta x} \mathrm{dx}
$$

Onde Px é a probabilidade de haver um segmento de comprimento entre $\mathbf{x}$ e $\mathbf{x}+\mathbf{d x} ; \mathbf{x}$ é o comprimento do segmento; $\mathrm{e}_{-}$a densidade média de pontos por unidade de comprimento (Malt 1991:48).

Para os elementos_F,_G,_D respectivamente frequência, intensidade e densidades cálculos são feitos através das leis estocásticas de probabilidade contínua: 


$$
\mathrm{Pj}=\frac{2}{a}\left(1-\frac{j}{a}\right) \mathrm{dj}
$$

Onde $\mathrm{P}_{\mathrm{j}}$ é a probabilidade para que o intervalo esteja situado entre $\mathrm{j}$ e $\mathrm{j}+\mathrm{dj}$; j é o comprimento do intervalo; e $a$ é o comprimento do registro ou densidade. (Malt 1991:42)

Uma tela $\Delta \mathrm{F} \Delta \mathrm{G} \Delta \mathrm{t}$ pode ter sua densidade $\Delta \mathrm{D}$ variável de acordo com a fórmula de Poisson com já estudada anteriormente.

Um grão pode ainda ser considerado como um vetor onde uma duração específica por grão como 0.04 segundos por grão e os parâmetros de intensidade e frequência variáveis, ou seja um grão pode ser uma espécie de glissando muito pequeno, cujo comprimento seja bem curto. Para isso o compositor utiliza a lei de Boltzmann e Maxwell, abordando os glissandos como se fossem temperaturas de um estado gasoso, em que quanto maior a temperatura, maior é o número de glissandos. O compositor considera ainda que a sobreposição de grãos deve ser evitada, ou seja, a ocorrência de grãos num mesmo intervalo de tempo deve ser evitado especialmente quando a duração do grão for da ordem de 1.5 segundos, embora admitindo que no caso de grãos muito pequenos da ordem 0.04 segundos possa ocorrer.

\subsubsection{Operações com os Eventos Sonoros ou Telas}

Como vimos acima é possível elaborar diferentes massas sonoras com base em sons granulares (teoria de Gabor) e diferentes distribuições probabilísticas. Xenakis no entanto aplica às diferentes massas sonoras um conceito emprestado da termodinâmica: a entropia . A trajetória da entropia absoluta à nula equivale a transição da probabilidade de 0 à 1 . De acordo com a lei de evolução de Carnot-Clausius, a entropia de um sistema fechado diminui constantemente (Borel 1956: 64-65).

Ao invés de falarmos em probabilidade de um estado, podemos falar em ordem ou desordem ou grau de ataxia. Se num conjunto de grãos por exemplo, numa determinada duração, o surgimento de grãos se dá em intervalos regulares a probabilidade temporal é 1, o que caracteriza ordem e a entropia é nula, pois não há variedade alguma. Se um conjunto 
de grãos, cuja duração é suficientemente longa, obedece à distribuição exponencial então a probabilidade é 0 , a entropia é absoluta caracterizando desordem total na massa sonora. Isso se dá porque a distribuição exponencial, de natureza probabilística, não especifica ordem como por exemplo, a distribuição numa região específica de um parâmetro sonoro, fornece dados de distribuição para todo o espaço gerido, caracterizando homogeneidade. $\mathrm{O}$ mesmo argumento é válido para as frequências $\Delta \mathrm{F}$, ou seja, a massa sonora constituída de uma única frequência tem entropia nula e probabilidade de variedade igual a 1. O mesmo vale para a intensidade $\Delta \mathrm{G}$ e a densidade $\Delta \mathrm{D}$. Dessa maneira as transformações de uma massa sonora em outra de características podem ser operadas de acordo com o conceito de entropia. Assim uma massa sonora perfeitamente ordenada pode ser transformada em uma outra parcialmente ou totalmente desordenada nos diferentes parâmetros. Num conjunto de grãos as intensidades podem ir de uma ordem parcial à desordem total enquanto as frequência podem partir da desordem total a um estado de ordem total. Todo tipo de manipulação é possível. Xenakis estabelece portanto quatro graus com os quais irá trabalhar para a criação das massas sonoras:

$$
\text { Desordem Perfeita }=\infty
$$

Desordem Parcial $=n$ ou $m$

Ordem Parcial $=m$ ou $n$

Ordem Perfeita $=0$ 


\begin{tabular}{|c|c|c|c|c|c|c|c|c|c|}
\hline \multicolumn{2}{|c|}{$\begin{array}{l}\text { Désoxdre } \\
\text { perfait }\end{array}$} & \multicolumn{2}{|c|}{$\begin{array}{l}\text { Dés orare } \\
\text { partiel }\end{array}$} & \multicolumn{2}{|c|}{$\begin{array}{l}\text { Ordre } \\
\text { parfait }\end{array}$} & \multirow[t]{2}{*}{ Symbole } & \multirow{2}{*}{ Observations } & \multirow{2}{*}{ Sohèmas } & \multirow{2}{*}{ Schrmas } \\
\hline $\mathrm{P}$ & $G$ & $\mathrm{~F}$ & G & $P$ & G & & & & \\
\hline F & G & & & & & $\infty \cdot \infty$ & trame unique & $\%$ & \\
\hline $\mathrm{F}$ & & & G & & & $\infty \cdot n$ & $\begin{array}{l}\text { infindté } \\
\text { do trattes }\end{array}$ & 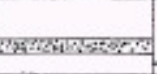 & \\
\hline \multirow[t]{7}{*}{$P$} & & & & & 0 & $\infty \cdot 0$ & trame unique & & \\
\hline & G & B & & & & $2 \cdot \infty$ & $\begin{array}{l}\text { Infinite } \\
\text { de trames }\end{array}$ & 商 & \\
\hline & Q & & & $\mathrm{P}$ & & $0 \cdot \infty$ & $\begin{array}{l}\text { trame unique } \\
\text { song purs }\end{array}$ & & \\
\hline & & P & G & & & $n \cdot m$ & $\begin{array}{l}\text { Infinité de } \\
\text { trentes }\end{array}$ & siging & \\
\hline & & F & & & G & $\mathbf{n}, \mathbf{0}$ & $\begin{array}{l}\text { Infinité } \\
\text { de trames }\end{array}$ & - & $\cdots$ \\
\hline & & & G & $P$ & & $0 \cdot n$ & $\begin{array}{l}\text { infinite } \\
\text { de trames }\end{array}$ & | & $\vdots$ \\
\hline & & & & $\mathrm{P}$ & G & 0.0 & $\begin{array}{l}\text { trane unique } \\
\text { (son pux) }\end{array}$ & - & - \\
\hline
\end{tabular}

Fig 3.7 - O gráfico acima apresenta uma tabela de entropia para diferentes eventos sonoros. Considerando o eixo vertical $\mathrm{G}$ (intensidade) e $\mathrm{F}$ (freqüência) diferentes estados e transições são possíveis tomando os casos básicos da figura. (Xenakis, 1962).

A construção das diferentes transições ao longo de um som complexo a partir da classificação acima pode ser obtida através de operações emprestadas da Teoria dos Conjuntos. Tais operações irão atuar como filtros, isso é válido para o compositor tanto no campo instrumental como no campo eletroacústico quando trabalha com sons senoidais. As operações de união, intersecção, disjunção, complementação e diferença são largamente utilizadas com a finalidade de criar um som complexo. A soma dos elementos de uma tela A com uma tela B é denominada união, diferença é a subtração dos elementos de uma tela $\mathrm{B}$ de uma tela $\mathrm{A}$, disjunção é o conjunto vazio sem elementos nem da tela $\mathrm{A}$ ou da tela $\mathrm{B}$ e intersecção a geração dos elementos comuns de uma tela A e de uma tela B. 


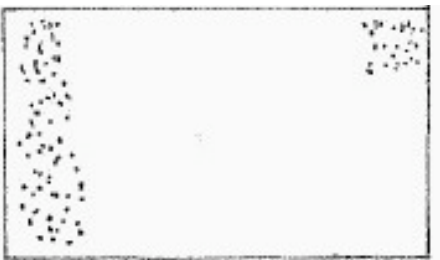

A

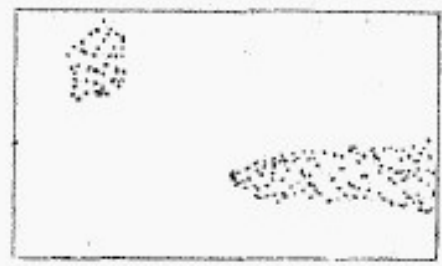

A
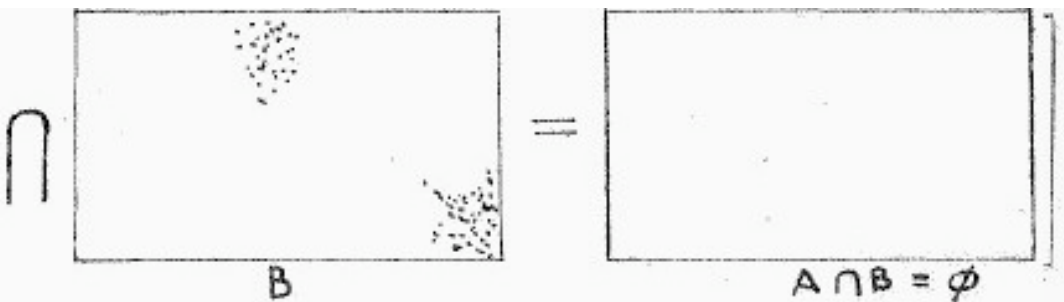

$A \cap B=\varnothing$

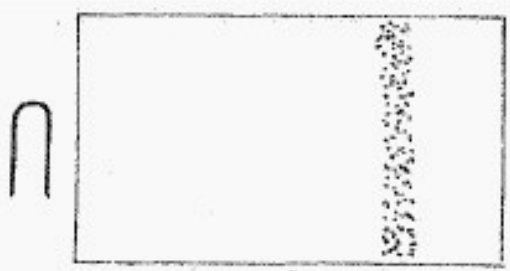

B

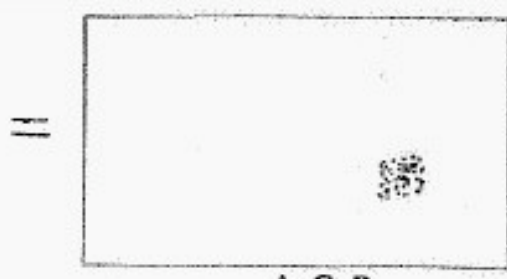

$A \cap B$

Fig 3.8 - Exemplo de operação sobre telas com base na Teoria dos Conjuntos.

\subsubsection{Ligação dos Eventos Sonoros numa Composição}

Todos os mecanismos podem ser representados por transformações sob cinco condições de correspondência: A) cada estado do mecanismo é uma correspondência um-a-um com um termo da transformação; B) cada sequência de estados permutados pelo mecanismo em razão de sua estrutura interna corresponde a uma sequência ininterrupta dos termos de transformação; C) se o mecanismo alcança um estado e lá permanece (estado absorvente ou estacionário), o termo que corresponde a esse estado sem transformador; D) se os estados de um mecanismo reproduzem a si mesmos da mesma maneira sem fim, a transformação tem um esquema cinemático num circuito fechado; E) um estacionamento do mecanismo e seu início de outro estado é representado no diagrama abaixo por um deslocamento do ponto representativo, que não se deve a uma seta mas a uma ação arbitrária no esquema (Xenakis, 1992: 73).

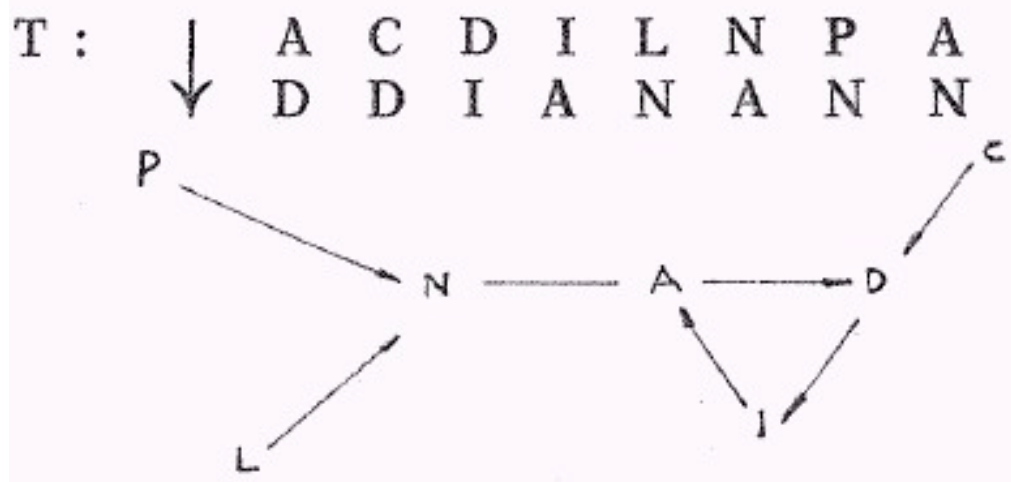


Fig 3.8 - Exemplo de diagrama de transformações de eventos sonoros (Xenakis, 1962)

Aqui adentramos novamente no campo das cadeias de Markov, onde inúmeras transformações são possíveis como vimos acima. A imprevisibilidade da sucessão de $\mathrm{A}$ ou de B poderia ser máxima e então a entropia seria absoluta. Inversamente, a entropia poderia ser zero. Para isso designa-se Matrizes de Probabilidade de Transição de estados ou eventos sonoros. Uma Matriz de Probabilidade de Transição indica a probabilidade de um ou mais estados passarem a outros.

É possível permutar duas ou mais Matrizes de Probabilidade de Transição de diferentes parâmetros na condição que uma transformação determinada ou estocástica será introduzida entre os vários parâmetros. Dessa maneira um protocolo de timbres pode ser permutado com um protocolo de intensidades e um protocolo de frequências, etc., e cada protocolo pode ser ligado em pares com todos os outros. Mecanismos isolados ou permutados podem ter um ou mais estados estacionários ou absorventes.

Se uma Matriz de Probabilidade de Transição é regular, isso é se há uma única probabilidade de transformação e a sequência de poderes crescentes da Matriz de Probabilidade de Transição se aproxima de uma certa matriz $T$, ela é chamada de distribuição estacionária ou estado de estabilidade de uma Matriz de Probabilidade de Transição.

Por exemplo, considere a seguinte seqüência representado por apenas dois eventos sonoros A e B:

\section{ABABBBABAABABABABBBBABAABABBAABABBABAAABABBABBAB} BA.

Suas freqüências de transições seriam:

$\mathrm{A} \rightarrow \mathrm{B}-17$ vezes e $\mathrm{A} \rightarrow \mathrm{A}-6$ vezes, perfazendo um total de 23 vezes que $\mathrm{A}$ transita para um outro evento; e B $\rightarrow$ A - 17 vezes e B $\rightarrow$ B - 10 vezes, perfazendo um total de 27 vezes que $B$ transita para um outro evento. Suas respectivas matrizes seriam: 


\begin{tabular}{|l|l|l|}
\hline$\downarrow$ & A & B \\
\hline A & 0.26 & 0.63 \\
\hline B & 0.74 & 0.37 \\
\hline
\end{tabular}

A matriz acima significa que a probabilidade de um evento A ser seguido de outro A é igual a $26 \%$, e assim, respectivamente para os outros valores.

Um critério fundamental de evolução de uma peça musical pode ser formatado por transformações da ataxia sobre o tempo. Por exemplo, não desencadear de uma só vez toda variedade possível, mas conte-las e introduzi-las pouco a pouco. É possível também imaginar uma peça musical que poderia inicialmente apresentar toda a variedade possível e então ser estilhaçada em elementos distintos durante a peça.

Aceitamos que um conjunto ou de telas pode ser expressado por matrizes de probabilidades de transição contendo parâmetros. Eles são afetados por um grau de ataxia ou entropia que é calculável sob certas condições. A ataxia de uma peça pode no entanto ser posta na forma de matriz com parâmetros e todas regras lógicas de acordo com as operações fundamentadas na Teoria dos Conjuntos são aplicáveis à Matriz de Probabilidade de Transição de entropia. Nos tópicos seguintes veremos como a estruturação acima é utilizada em duas composições.

\subsection{Analogique A}

A peça foi concebida entre os anos de 1958 e 1959, no mesmo período em que Analogique B foi composta. Sua formação instrumental, um pequeno conjunto de cordas de três violinos, três violoncelos e três violas, foi pensada numa escuta não saturada, capaz de rastrear as densidades, que no caso não atinge extremos como aqueles de Metastasis e Pithoprakta. A redução da massa orquestral permite que a escuta possa atentar-se às 
nuances granulares, e acompanhar o rastro mnemônico deixado ao longo de sua duração pelo mecanismo baseado nas cadeias de markov.

A representação dos elementos sonoros é vetorial, localizando as notas precisamente na estrutura global da peça. Um vetor sonoro é representado pelo espaço paramétrico de três variáveis distintas: freqüência, intensidade ou dinâmica, e densidade. Para cada parâmetro há uma extensão e porções distintas tomadas no interior dessa extensão, identificadas por algarismos romanos de I a IV. Embora a extensão seja sempre a mesma para cada parâmetro, as porções tomadas tem duas configurações distintas para cada um, identificadas pelos índices 0 e 1: fo e f1 (freqüências), i0 e il (dinâmicas) e d0 e d1 (densidades).

Por exemplo a extensão das freqüências vai de Mi0 até Lá5, sendo que A3 (440hz); a extensão dinâmica vai de $p p$ a ff; e as densidades de 1 a 9 sons por segundo. Em cada uma dessas extensões novas regiões delimitadoras foram especificadas tendo em vista facilitar a identificação das porções. As freqüências têm as seguintes regiões: 1-Mio a Mi1, 2-Mi1 a Ré2 , 3-Ré2 a Réb3, 4- Réb3 a C4, 5-C4 a B4, e 6-B4 a A5. As porções das freqüências no interior da extensão em fo são I- 1, II-2, III-5 e IV-6; e para f1 são I,II, e III-3 e IV-4. No caso das dinâmicas as regiões são 1-pp, 2-f e 3-ff. As porções das dinâmicas no interior da extensão para i0 são II,III-1; I-2; e IV-3; e para i1 são I,IV-1 e II,III-2, a região 3 não é utilizada. As densidades têm as seguintes regiões 1- 1 som por segundo, 2- 3 sons por segundo e 3- 9 sons por segundo. As porções no interior da extensão para do são II,III-1; I-2 e IV-3; e para d1 são IV-1; II,III-1 e I-3.

Delimitadas as extensões e porções para cada índice dos parâmetros, oito tipos de telas de A a H são combinadas. Cada tela tem uma duração de 1.11 segundos o $\Delta t$, e um conjunto de telas tem 33.3 segundos, cada conjunto é igual a $30 \Delta t$. As configurações das telas são as seguintes: A - foiodo, B - foiod1, C - f0i1d0, D - foi1d1, E - fliodo, F - foiod1, $\mathrm{G}$ - fli1d0 e H - f1i1d1. Deste modo um grande número de configurações para os diferentes parâmetros são possíveis sem perda de controle já que delimitações foram estabelecidas. Observe na figura abaixo o diagrama e as matrizes consquêntes. 

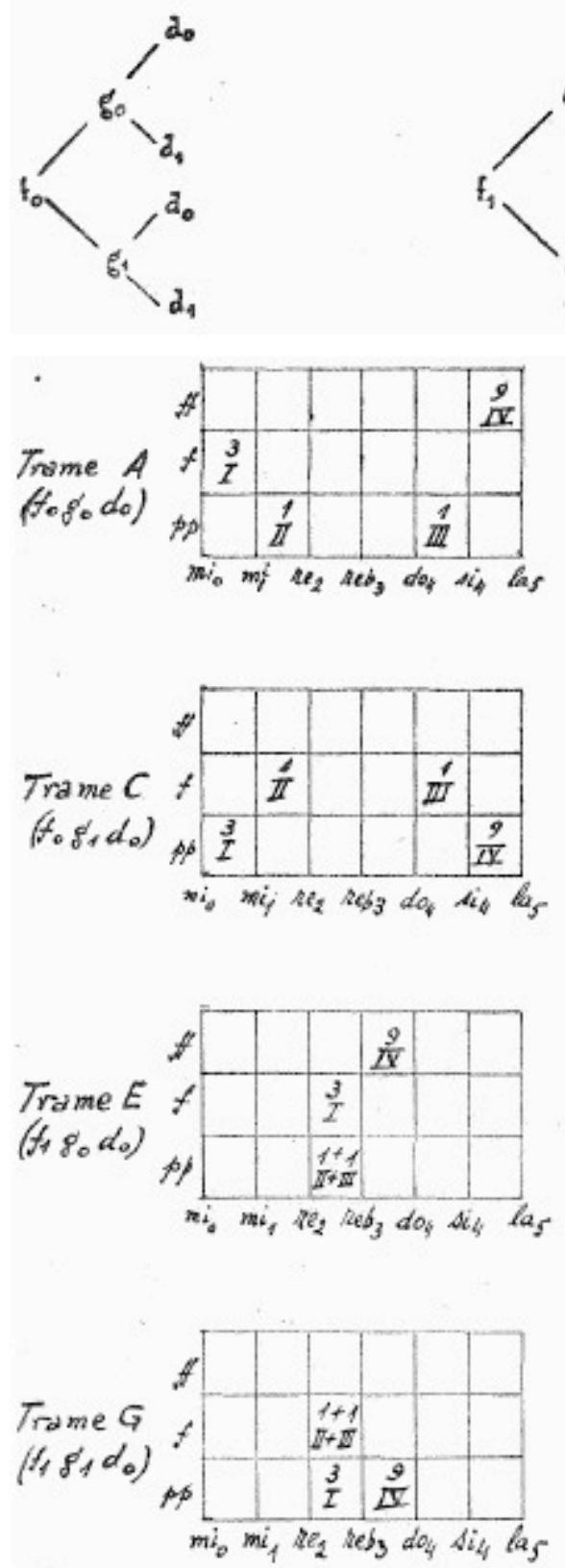
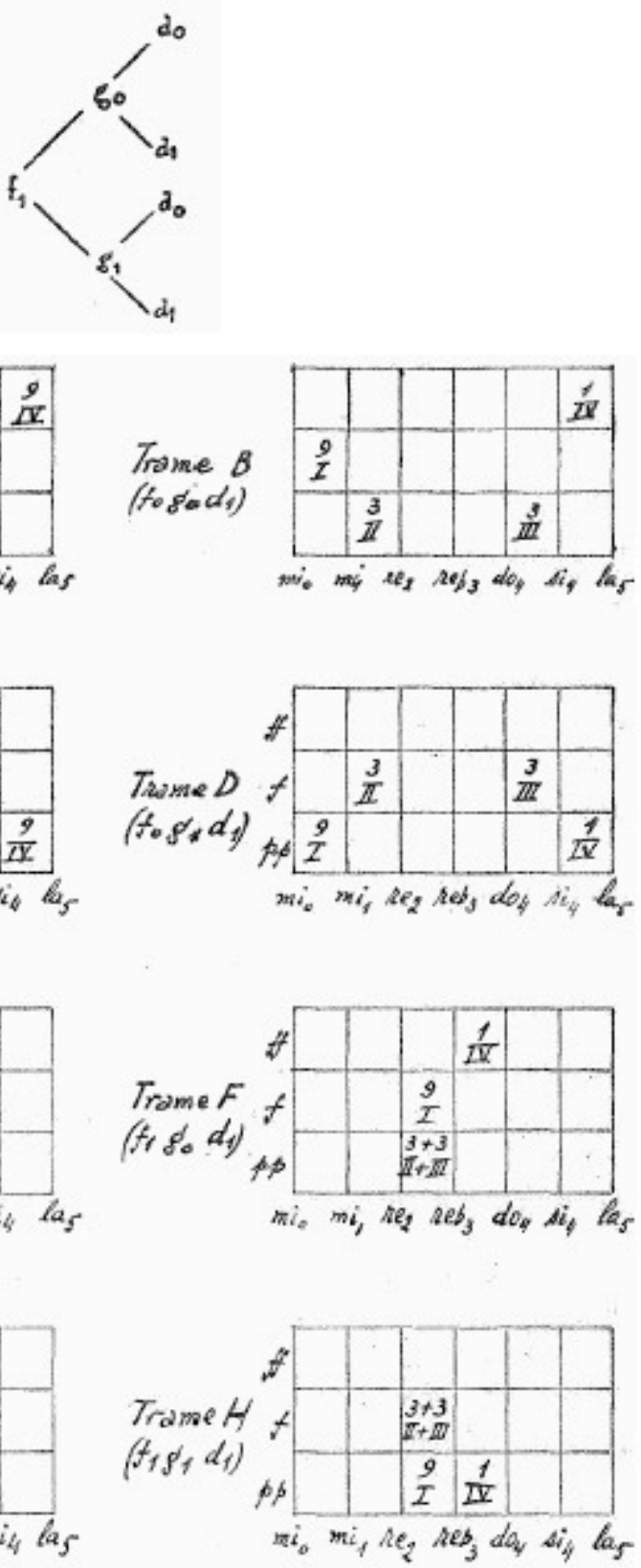

Fig 3.9 - Diagrama e suas conseqüentes matrizes da peça Analogique A. Note que i está indicado na figura como g. (Xenakis, 1962) 
Por fim um esquema cinético irá definir a obra segundo cadeias de markov, onde há um estado estacionário $\mathrm{E}$ e diferentes estados intermediários $\mathrm{P}$, que serão impostos para gerar perturbações no interior da peça. Para cada um dos estados uma cadeia de markov foi estabelecida para fornecer o conjunto de telas. Em Analogique A o mecanismo móvel oferecido por Xenakis é:

\section{$\mathrm{E} \rightarrow \mathrm{Pa}^{0} \rightarrow \mathrm{Pa}^{\prime} \rightarrow \mathrm{E} \rightarrow \mathrm{Pc}^{\prime} \rightarrow \mathrm{Pc}^{0} \rightarrow \mathrm{Pb}^{0} \rightarrow \mathrm{Pb}^{\prime} \rightarrow \mathrm{E} \rightarrow \mathrm{Pa}^{\prime}$}
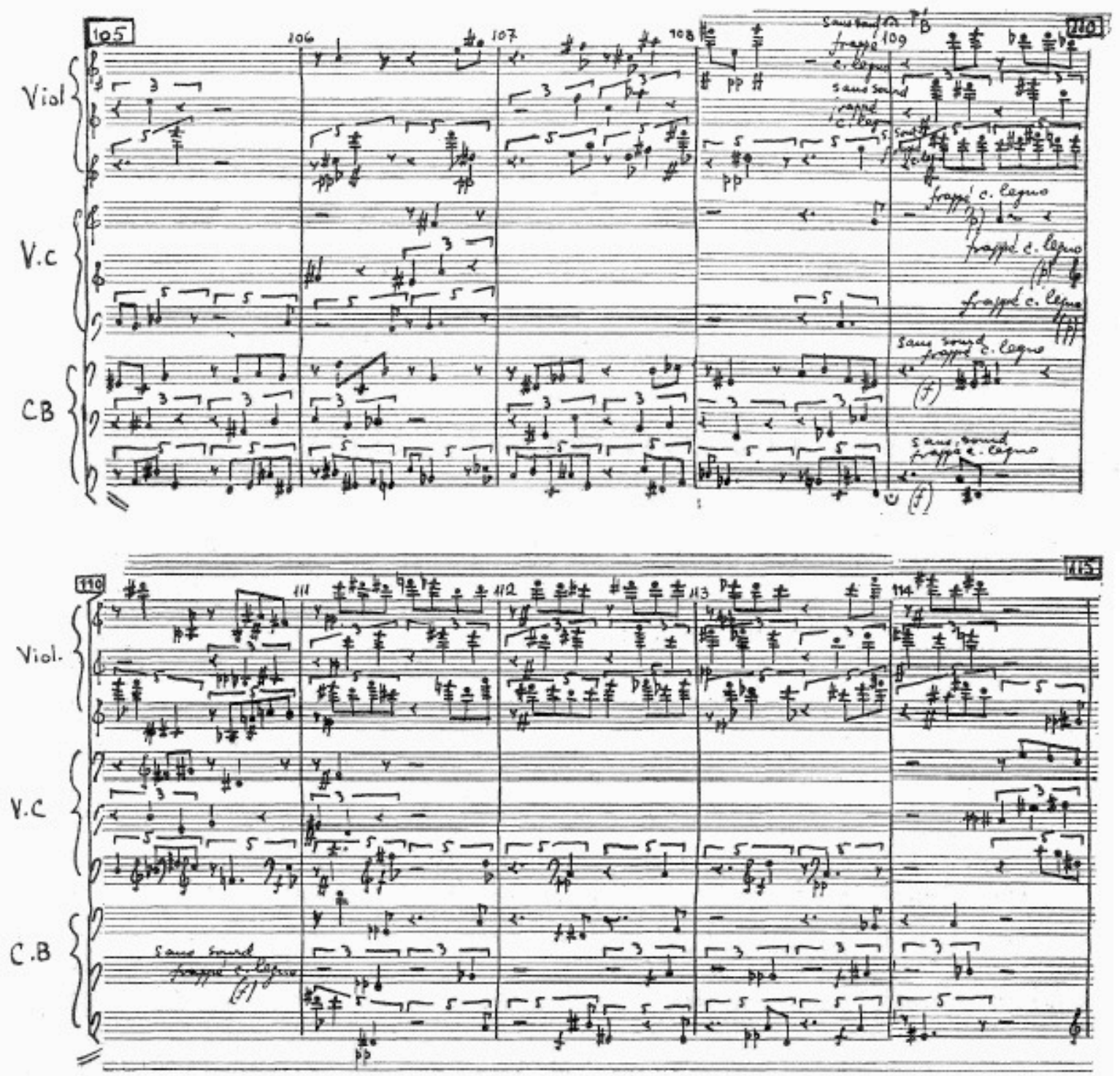

Fig 3.10 - Compassos 105 a 115 de Analogique A Xenakis, 1962). 


\subsection{Analogique B}

A peça de 1958- 59, composta a partir de breves sons senoidais gravados em fita magnética, tem como base a teoria de gabor, só que pela primeira vez abordada de uma perspectiva sintética. A possibilidade é explorada ao compor o som a partir de sobreposições de grãos senoidais de som.

Cada grão de Analogique B tem uma duração fixa de 0.04 segundos. Os valores de amplitude e frequência são localizados num plano fragmentado em células com uma área de $\Delta \mathrm{g} \Delta \mathrm{t}$ que Xenakis denomina "tela". Para obter sons dinâmicos, um "livro" de "telas" é usado, numa distância de $\Delta \mathrm{t}=0.5$ segundos.

As características globais de uma "tela" são

(1) a densidade de grãos no volume $\Delta \mathrm{g} \Delta \mathrm{f} \Delta \mathrm{t}$;

(2) o formato da distribuição do grão;

(3) o grau de ordem/desordem em tal distribuição.

A estratégia empregada por Xenakis lida apenas com a primeira delas. Consistindo num processo Markoviano implementado através de uma matriz de probabilidade de transição(MPT): a evolução da textura sonora é traçada pela probabilidade que num certo momento $t$ os parâmetros da tela serão modificados com respeito a $t-\Delta t$.

Uma simples MPT é parecida com a que segue:

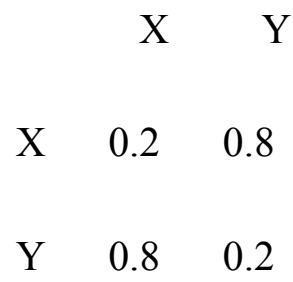

Representa a probabilidade

. X seguido de X (20\%) 
. X seguido de Y $(80 \%)$

. Y seguido de X (20\%)

. Y seguido de Y $(80 \%)$

Em Analogique B, duas MPTs foram utilizadas na determinação de valores de amplitude, densidade e frequência:

$\begin{array}{cccccc} & \mathrm{X} & \mathrm{Y} & & \mathrm{X} & \mathrm{Y} \\ \mathrm{X} & 0.2 & 0.8 & \mathrm{X} & 0.85 & 0.4 \\ & & & & & \\ \mathrm{Y} & 0.8 & 0.2 & \mathrm{Y} & 0.15 & 0.6\end{array}$

$\mathrm{X}$ e Y são associados com dois conjuntos de valores selecionados entre 16 regiões de frequências ( cada uma correspondendo a uma oitava), dois conjuntos selecionados entre 4 regiões de amplitudes e dois conjuntos selecionados entre 17 regiões de densidade (em unidades logarítmicas).

Um controle macroscópico adicional utilizado por Xenakis é chamado de protocolo de permuta entre perturbação de estados e estados estacionários. Esse protocolo é empregado para determinar os valores de parâmetros internos da MPT para cada seção da peça, oito no total de um todo de 2'35'. O protocolo de permuta estabelece a alternância do comportamento sonoro da entropia crescente ou perturbações $\mathrm{P}$ e comportamentos mais estáticos ou pontos de equilíbrio E.

Esses detalhes visão muito clara dos vários níveis do processo composicional:

(1) a representação granular fornecida ao compositor com elementos mínimos discretos;

(2) a manipulação desses elementos (microcomposição) resulta no verdadeiro material sonoro para todo o trabalho; 
(3) o conceito de "tela" representa o esquema de controle, conectando a microcomposição com o critério do menor termo (MPT) com o maior termo do design musical (protocolo de permuta $P$ e $E$ ).

Em resumo Analogique B reflete a abordagem quântica que Xenakis emprestou de Gabor bem como métodos estatísticos utilizados em trabalhos instrumentais do mesmo período.

\section{$\underline{\text { 3.6 Analogique } A+B}$}

A junção das duas peças emblemáticas da música estocástica markoviana revela para o ouvinte o diálogo de duas massas sonoras distintas, uma de sonoridade instrumental clássica (cordas) e a segunda sintética (sons senoidais). Ambas obedecem princípios semelhantes, se desenvolvem ao longo de um mesmo destino. Xenakis faz com que sua composição traga uma transformação nebular de grandes proporções num lugar remoto do universo e uma formação nebular microscópica como o crescimento de cultura bacterial através de um mesmo princípio. Abstrai do muito grande e do muito pequeno granularidades redutíveis à apreensão da escuta num instante particular, que quando comprimidas e unificadas no espaço-tempo desvelam um pequeno estilhaço da magnitude do universo. 


\section{MÚSICA SIMBÓLICA}

Xenakis sugere que deveríamos nos imaginar tomados por uma repentina amnésia, que o ouvinte ponha de lado sua formação (podemos incluir aqui qualquer conhecimento prévio) musical (Xenakis, 1992:155). Apresentaremos neste capítulo os princípios teóricos de sua Música Simbólica juntamente com suas aplicações, notavelmente a peça para piano Herma (1960-61). Devemos ressaltar que os conceitos aqui apresentados estão de acordo com os escritos do próprio compositor, assim como apresentados nos textos incluídos na obra teórica Formalized Music (1992). Tal edição embora seja em inglês, e não na língua de origem, o francês, constitui a reunião mais abrangente dos escritos do autor e é utilizada como referencial por todos pesquisadores que se dedicam às suas teorias e aplicações.

O compositor espera alcançar maior compreensão musical, partindo da teoria dos conjuntos e seus subseqüentes esquemas lógicos. Não há aqui quaisquer fundamentos estéticos baseados em teorias acústicas. Toma como base apenas duas constatações:

\section{Escuta e;}

2. Capacidade de compreensão lógica dos fenômenos relacionados à escuta.

A despeito de tal simplicidade, Xenakis espera com isso erigir um projeto ainda maior, abarcando tanto a compreensão do passado musical como a construção de novas composições.

Esperamos elucidar um aspecto teórico da obra de Xenakis que não se reporta às probabilidades matemáticas, ao acaso matemático, característica pelo qual é comumente lembrado, mesmo tendo se dedicado à outras teorias.

A elaboração teórica ocupa um grande espaço em sua trajetória musical. Verificamos a dedicação intensa do compositor em erigir uma teoria que fosse eminentemente prática, cuja aplicação fosse maleável no trato do material musical. Ao contrário de suas ambições estocásticas que na maioria dos casos demandavam intenso labor teórico (ver Achorripsis e peças $S T$ ), este parece, pouco a pouco, mostrar-se um tanto cansativo e limitante das escolhas do compositor, daí a abertura para uma nova teoria. O 
projeto estocástico (retomado apenas na década de 1990), daria lugar no início da década de 1960 à ampliação formal da composição musical, antes tão relegadas à natureza probabilística dos fenômenos. Tal ampliação seria verificada, no trato do parâmetro altura num primeiro momento, que se não chega ao ponto de demonstrar uma preocupação de natureza estritamente harmônica, indica maior atenção dada ao parâmetro, dentro de uma perspectiva lógica.

A teoria apresentada é a base de uma ferramenta lógica criada posteriormente à realização de Herma: as Sieves (Crivos). Tal teoria proporcionaria ao compositor um método de esquematização de filtros lógicos, inicialmente aplicados largamente ao campo das alturas, mas estendíveis a outros parâmetros como tempo, amplitude e até mesmo parâmetros mais complexos como densidade. As Sieves no entanto não são o mesmo que música simbólica, embora nela encontre-se seus fundamentos, estas seriam desenvolvidas numa série de textos e sua versão final apareceria apenas na década de 1970.

\subsection{A SimbOLIZAČ̃̃o dA MÚSICA}

A Música Simbólica é caracterizada por reportar-se aos princípios da lógica clássica formal com o intento de criar música. Tal movimento é um tanto fugaz, o entrelaçamento dos fios que conduzem à etapa final da realização musical nem sempre são facilmente capturados num primeiro momento. Podemos dizer que a maior parte desses fios são compreendidos à luz da lógica formal como já dissemos, somente ela não é capaz de nos levar ao fato musical propriamente dito. Uma pequena parte dos fios desse grande tecido, não menos importante, busca em tópicos da matemática e da física sua realização sonora definitiva. Não é objetivo dessa dissertação ocupar-se demasiadamente da lógica e suas linguagens e como se relacionam com as artes. Mas é impossível fugir de alguns fundamentos da lógica sem os quais estaríamos correndo o risco de nos tornarmos incompreensíveis.

De acordo com a definição proposta por Mortari, a lógica pode ser compreendida como:

" a ciência que estuda princípios e métodos de inferência, tendo o objetivo principal de determinar em que condições certas coisas se seguem (são conseqüência), ou não, de outras. (Mortari, 2001:2) 
A teoria de Música Simbólica abrange três etapas: a linguagem musical formal, escala inicial; formalização de conjuntos musicais, escala média; e obra musical, a forma total, escala global. Um conceito lógico será sempre considerado com relação ao seu análogo sonoro imediato. Isso deve ficar claro, pois não estamos tratando de lógica pura, mas sim de como ela se acopla ao dado sonoro tornando tal relação factível. Primeiramente investigaremos a linguagem musical formal, e como veremos ocupa a maior parte da exposição teórica, já que ela é a base para os outros níveis. Investigada a linguagem partiremos para a compreensão da formalização dos conjuntos sonoros que serão englobados numa composição. Por último vamos analisar a composição Herma (1960-61), para piano solo, a escala global, onde linguagem e formalização dos conjuntos são trabalhados de maneira que resultem numa composição.

\section{$\underline{4.2}$ A Linguagem Musical Formal}

Além de reportar-se aos princípios da lógica clássica, a linguagem também abarca tópicos matemáticos e físicos periféricos, normalmente não relacionados à teoria dos conjuntos e à lógica clássica. Essa abrangência tem a intenção de tornar a linguagem funcional, nada mais que uma preparação da matéria sonora em terreno lógico, somente após esta realização é que a matéria dá lugar ao material. A preparação é realizada em três níveis: a. compreensão do paralelo entre elemento geral (lógica pura) e elemento sonoro (acústica); b. compreendido o elemento sonoro é necessário fazer um paralelo com um conjunto numérico que irá validar o elemento sonoro, tornando-o acusticamente factível e c. tornado o elemento sonoro factível é necessário, finalmente, formaliza-lo através de uma combinação entre vetor e equação linear. A intenção da cadeia de raciocínios de Xenakis é ir da abstração lógica mais simples à mais complexa desde que seja realizável. Entre um ponto e outro alguma coisa precisa acontecer para que o elemento sonoro não se perca, seja sempre conseqüência. Estes níveis abrangem, gradativamente, assuntos como: conceito de vetor, conjuntos numéricos (particularmente o dos números reais), equações lineares e progressão aritmética.

Tal aglomeração de assuntos, a primeira vista pode parecer confusa, mas é uma linguagem dirigida à expressão lógica da fenomenologia sonora. Se o objetivo último do compositor é a obtenção potencial de formas, a demonstração da linguagem que a torna 
possível necessita rigidez, coerência e coesão. A linguagem, como apresentada pelo compositor, não pressupõe que o leitor esteja familiarizado com os tópicos lógicos, físicos e matemáticos abordados, mas sim que os mesmos eram naturais ao compositor. Os tópicos abordados pelo compositor eram familiares a ele desde sua juventude, e a partir de então, constantemente refletidos, resultado de sua maturidade estética. Se a teoria saída do próprio punho do compositor aparenta obscuridade para o leigo, isso não significa que a aliança entre os aspectos abstratos e sonoros são incorretos. Essa aliança estava de tal modo integrada na mente do compositor que quando ele a expôs, o fez naturalmente, quase para si mesmo, sem pensar em leitores específicos. Nossa intenção é investigar a linguagem, separando os detalhes com a intenção de expandir ao máximo a cadeia de raciocínio do próprio compositor, pretendendo que ao final o leitor consiga apreender a linguagem de maneira uniforme.

\subsubsection{Elemento: Caso Sonoro Geral ${ }^{1}$}

Primeiramente vamos entender o conceito de seqüência e como este se alinha aos dados sonoros, ou seja, como um elemento genérico, compreendido dentro de um caso geral dá lugar a elementos que, a posteriori, serão elementos sonoros que comporão uma seqüência. Devemos enfatizar que há uma diferença entre elemento de uma seqüência e elemento de um conjunto. Uma seqüência contém elementos, cuja ordem é levada em consideração. Um conjunto contém elementos cuja ordem não é levada em consideração, pode conter seqüências, uma única seqüência ou apenas elementos comuns não listados numa seqüência, elementos e seqüências, enfim, um conjunto é somente caracterizado pelos elementos que contém, pouco importando a ordem em que aparecem. Isso não significa que um conjunto contenha apenas elementos arbitrários. Ele pode obedecer leis, funções, etc, que definem quais elementos pertencem ou não ao conjunto, mas não devemos confundir com ordem dos elementos.

Consideremos 'a' um elemento sonoro qualquer de duração finita. Este mesmo elemento é neutro, nem agradável, nem desagradável. Descartamos, por hora, qualquer aspecto qualitativo, sem distinção de altura, timbre ou qualquer outro parâmetro. Sabemos

\footnotetext{
${ }^{1}$ Reportamos o leitor à Introdução desta dissertação para maiores esclarecimentos sobre Lógica e Teoria dos Conjuntos.
} 
apenas que 'a' é um evento sonoro finito no tempo. Quando sucedido por ele mesmo apenas nos leva concluir que são idênticos e nada mais. O elemento sonoro 'a', assim descrito, significa que é afirmado, dada sua repetição e sua duração finita. Sua repetição é uma tautologia ${ }^{2}$, ou seja 'a' é 'a' mesmo, jamais outro elemento:

a $\vee$ a $\vee$ a $\vee$ a $\ldots \vee$ a $=a$

O operador $v$ significa que o elemento é repetido, posto lado-a-lado, sua repetição não implica em sucessão temporal mensurável, desconsiderando por enquanto, ocorrência temporal.

Considere dois elementos sonoros ' $a$ ' e ' $b$ ' tal que ' $a$ ' é diferente de ' $b$ '. Ao percebermos ' $a$ ' e ' $b$ ' notamos que são elementos sonoros distintos. Suas durações ou ordem em que são emitidos não são importantes. Sabemos apenas que 'a' é distinto de 'b'. Temos então:

$$
\begin{gathered}
a \neq b \\
a \vee b=b \vee a
\end{gathered}
$$

Se temos três elementos distintos 'a', 'b' e 'c', passa a valer a lei comutativa. Isso significa que é possível a combinação de dois elementos para originar uma seqüência distinta:

$$
(a \vee b) \vee c
$$

A lei associativa também é válida e não gera diferença:

$$
(a \vee b) \vee c=a \vee(b \vee c)
$$

Por outro lado, ao considerarmos a ocorrência temporal dos eventos 'a', 'b' ou 'c', onde temos o operador _ que significa "anterior a", a lei comutativa é inválida já que

$$
a_{-} b \neq b_{-} a
$$

\footnotetext{
${ }^{2}$ Tautologia - Independentemente das proposições serem verdadeiras ou falsas a conseqüência é sempre verdadeira.
} 
Como vimos, inserção no tempo acarreta um diferenciador, a emissão de uma seqüência sonora tal que a emissão de dois elementos distintos, 'a' anterior ao 'b', configura uma seqüência distinta da seqüência ' $b$ ' anterior ao 'a'. Mas de acordo com Xenakis, a diferenciação temporal (assimetria) é como se fosse um cacoete cognitivo, resultado da experiência tradicional de percepção que implica na correspondência um-a-um entre elementos sonoros e instantes de tempo. (Xenakis, 1992:157) Durações distintas, ausentes de elementos sonoros, independem da ordem em que aparecem ou se associam, não representam diferenças. O compositor ainda considera que o tempo em si, vazio, mensurável, que não contém eventos, apreendido como duração é suscetível das propriedades comutativa e associativa:

$$
\begin{gathered}
a_{-} b=b_{-} a \quad \text { lei comutativa } \\
\left(a_{-}\right)_{-} c=a_{-}\left(b_{-} c\right) \quad \text { lei associativa }
\end{gathered}
$$

Consideremos um caso particular, as teclas de um piano, tal que, cada tecla corresponde a um elemento sonoro distinto. Dada a execução de uma tecla 'a' e sua repetição, descartando intensidade e duração, obtemos um elemento sonoro. Ao tomarmos duas teclas distintas 'a' e 'b', na extensão do piano, e sua execução independente da ordem em que ocorrem, temos então uma seqüência sonora distinta. $\mathrm{O}$ mesmo acontece com a inclusão de uma terceira tecla distinta 'c', a execução das três teclas 'a', 'b' e 'c', independentes da ordem em que são emitidas configuram uma seqüência sonora distinta.

O caso particular acima, teclas de um piano, também é válido para qualquer outro caso sonoro particular. Como dissemos, não estamos considerando qualificação sonora. Investigamos a capacidade de diferenciação de elementos sonoros e a possibilidade de encadeamento lógico desses elementos. Por enquanto estamos tomando entidades como 'a', 'b' e 'c' como elementos sonoros genéricos e suas conseqüentes possibilidades de organização. Sabemos apenas que tais entidades ('a', 'b' e 'c') são elementos sonoros'.

\footnotetext{
${ }^{5}$ Designaremos conjuntos sonoros por letras maiúsculas 'A', 'B', ou 'C'. Minúsculas como 'a', 'b' ou 'c', designam elementos de conjuntos. Pares ordenados são designados por parênteses ( ), qualquer elemento entre estes símbolos designa um par ordenado, como (a,b,c) ou (c,b,a).
} 
Apenas para não permanecer num terreno puramente abstrato, Xenakis utiliza como exemplo o dado altura, da perspectiva de um indivíduo amnésico, ou seja, um indivíduo que momentaneamente, ao tratar de alturas, descarta todo conhecimento prévio para possibilitar uma perspectiva não condicionada do dado "altura" (perspectiva harmônica tradicional). Dessa maneira, tomando dois elementos sonoros 'a' e 'b', não é suficiente para ele perceber satisfatoriamente uma noção segura de intervalo ou distância. $O$ indivíduo procurará então por um terceiro elemento 'c' que permita estabelecer comparações. Ao tomar três alturas distintas 'a', 'b' e 'c', um indivíduo (em condições normais de percepção) é capaz de perceber que a distância entre 'a' em relação a 'b' é diferente de 'a' em relação a 'c'. Se os dados fornecidos fossem apenas 'a' e 'b', o indivíduo teria uma única sensação de distância. Um indivíduo, musicalmente treinado na tradição, consegue distinguir um intervalo de quinta justa ou oitava dada duas notas 'a' e 'b' sem necessitar de uma terceira 'c' para estabelecer comparações. Mas isso não importa pois dois dados de altura são “quaisquer" dados de altura, podendo adentrar inclusive no terreno microtonal que a tradição não abrange.

\subsubsection{Um Novo Conceito de Nota}

Os conceitos aqui apresentados estão em acordo com a Teoria dos Grupos ${ }^{6}$. Xenakis oferece a seguinte notação, já existente, aqui em paralelo com elementos sonoros, capaz de abranger não só alturas mas intervalos melódicos também. Dado um conjunto de alturas H, e seus elementos ' $h n$ ', temos um conjunto de intervalos:

$$
\begin{aligned}
& \mathrm{H}=\left\{\mathrm{h}_{\mathrm{a}}, \mathrm{h}_{\mathrm{b}}, \mathrm{h}_{\mathrm{c}}, \ldots\right\} ; \\
& \text { e a relação binária } \geq \text { (maior ou igual a...). }
\end{aligned}
$$

\section{Temos:}

1. $\mathrm{h} \geq \mathrm{h}$, para todo $\mathrm{h} \in \mathrm{H}$, reflexividade; $(\in$, símbolo que indica relação de pertencimento)

\footnotetext{
${ }^{6}$ A teoria dos grupos é uma das partes mais importantes da matemática, inclusive em aplicações e na sistematização das ciências empíricas. Se além das propriedades aditiva, associativa e elemento neutro valer uma quarta comutativa, os grupos são conhecidos também como abelianos (Costa e Krause, 2005:18)
} 
2. $h_{a} \geq h b \neq h b \geq h_{a}$, exceto para $h a=h b$, antissimetria;

3. Se $h_{a} \geq h b$ e $h b \geq h_{c}$, então ha $\geq h c$, transitividade.

Tal notação permite a designação de seqüências em acordo com uma unidade intervalar adotada para o mesmo. Visando a clareza na confecção de uma seqüência, o compositor leva em conta o dado altura dentro dos limiares de percepção da escuta humana $^{7}$. Os conjuntos nunca serão compostos de elementos que causem dubiedade ou dúvida com relação à diferença intervalar entre seus elementos. Dada as limitações da escuta, é possível confeccionar qualquer conjunto de diferentes propriedades acústicas. Os parâmetros acústicos são aqueles aos quais a escuta se dirige imediatamente: freqüência (sensação de altura), amplitude (sensação de volume), e duração (experiência temporal).

O conceito de nota é retomado com base nos axiomas de $\mathrm{Peano}^{8}$, para as quais Xenakis estabelece alturas, e estende para os outros parâmetros fundamentais utilizando os mesmos axiomas. O compositor afirma que podemos construir a escala cromática, de tom inteiro ou qualquer outra escala por meio de três termos primitivos: origem, nota e sucessor da nota. Daí a transposição dos axiomas de Peano para as notas:

1. A origem é uma nota;

\footnotetext{
7 Limiar humano de percepção - Dados de altura entre $20 \mathrm{~Hz}$ e $15 \mathrm{Khz}$ são percebidos como som por uma pessoa normal . A sensação de volume varia entre $60 \mathrm{db}$, limiar de audibilidade e $120 \mathrm{db}$, limite da dor. Durações acima de 0,1s correspondem a percepção de notas, sucessão e ritmo (Roederer, 2002). Estes valores são aproximados para mais ou para menos, e variam de um indivíduo para outro, devem ser compreendidos como limites mínimos.

8 A teoria de Peano afirma que os números naturais podem ser apresentados como um conjunto em cuja existência vale um reduzido número de axiomas. O método de Peano se apóia no fato de que os números naturais podem ser ordenados numa seqüência, na qual cada elemento tem um sucessor bem definido. Por causa disso, diz-se "uma teoria ordinal". São três os conceitos primitivos: número natural, zero e sucessor que se relacionam entre si por cinco axiomas. O sucessor de n é simbolizado por_(n) e como usual, 0 para zero.

Os axiomas são os seguintes:

1. 0 é um número natural.

2. Todo número natural tem um "sucessor" _(n).

3. 0 não é "sucessor" de nenhum número.

4. Se_(n)=_(m), então $\mathrm{n}=\mathrm{m}$.

5. Princípio da Indução Completa: Seja $S$ um conjunto de números naturais tal que: (a) $0 \in S$; (b) $\mathrm{Se} n \in \mathrm{S}$, então_(n) $\in \mathrm{S}$.

Então, S é o conjunto de todos os números naturais. (Milies, 2003:177-178).
} 
2. O sucessor de uma nota é uma nota;

3. Notas que tem o mesmo sucessor são idênticas;

4. A origem não é sucessor de nenhuma nota; e

5. Se a propriedade se aplica à origem, e se quando se aplica a qualquer nota também se aplica ao seu sucessor, então se aplica a todas as notas (Princípio da Indução Completa). (Xenakis, 1992: 159)

Dados os cinco axiomas acima estabelecidos podemos compreender cinco propriedades que regem as notas. As cinco propriedades são:

1. Propriedade aditiva. Considere um conjunto $\mathrm{H}$ de intervalos de alturas. A lei de composição interna afirma que para cada par (ha, hb) $\in \mathrm{H} \mathrm{um}$ terceiro elemento pode ser correspondido. Este é o composto de ha por $\mathrm{hb}$, ha $+\mathrm{hb}=\mathrm{hc}$, tal que hc $\in \mathrm{H}$. Por exemplo, considere três sons caracterizados pelas alturas I, II, e III e considere h(I,II), h(II,III) os intervalos em semitons separando os casais (I,II) e (II,III), respectivamente. O intervalo h(I,III), compreendido entre um I e III, será igual ao campo de dois semitons dos outros dois, ou seja, um tom. Podemos portanto estabelecer a lei de composição para intervalos conjuntos e a adição dos mesmos.

2. $\quad$ P r o p r i e d a d e a s s o c i a t i v a. $h a+(h b+h c)=(h a+h b)+h c=h a+h b+h c$

3. Propriedade do elemento neutro. Há um elemento neutro h0 tal que, para todo ha $\in \mathrm{H}, \mathrm{h} 0+\mathrm{ha}=\mathrm{ha}+\mathrm{h} 0=$ ha. Para altura o elemento neutro é o uníssono ou intervalo zero; para intensidade o intervalo zero não tem nome; e para duração é simultaneidade.

4. Para cada ha existe um elemento especial h'a, chamado inverso tal que: h'a + ha $=h a+h$ 'a $=0$. Correspondente a um intervalo ascendente ' $h a$ ', há um intervalo descendente ' $h$ ' $a$ '; para um intervalo crescente de intensidade 
(em decibéis positivos) pode ser adicionado outro decrescente (em decibéis negativos), intervalo tal que cancele o efeito do outro; correspondente a um intervalo de tempo positivo há um outro negativo, duração negativa, tal que o campo dos dois é 0 ou simultaneidade.

5. A lei é comutativa: ha $+\mathrm{hb}=\mathrm{hb}+\mathrm{ha}$. (Xenakis, 1992:159)

Dessa maneira cinco propriedades foram estabelecidas para o parâmetro altura, forado-tempo (termo em francês), mais os exemplos estendidos para os parâmetros duração e intensidade. Concluímos que uma nota para ser definida cabalmente necessitamos dos conjuntos I (intervalos de intensidade) e $\mathrm{D}$ (durações), além do conjunto $\mathrm{H}$ (intervalos de alturas).

\subsubsection{Vetor Sonoro 9}

Xenakis oferece uma representação vetorial das notas que possibilitará o manuseio de todos elementos, sua localização exata tanto no conjunto como no interior da peça. A linguagem vetorial é estabelecida visando os aspectos funcionais sem os quais não é possível nenhuma realização.

Dados os três conjuntos H (alturas), I (intensidades) e D (durações) podemos representar um vetor da seguinte maneira:

$\mathrm{X}=(\mathrm{x} 1, \mathrm{x} 2, \mathrm{x} 3)$, que correspondem respectivamente aos conjuntos $\mathrm{H}$, I e D.

9 Conceito de Vetor - Em Física há dois tipos de grandezas: escalares e vetoriais. As grandezas escalares são aquelas caracterizadas por um número seguido de uma unidade de medida (temperatura, massa, volume, etc.), sua intensidade. Além da intensidade, as grandezas vetoriais são também caracterizadas pela sua orientação espacial, devido ao deslocamento dos corpos no espaço. Entre as grandezas, que necessitam do conhecimento de sua intensidade e orientação espacial, podemos citar: força, velocidade, quantidade de movimento, etc.

A orientação espacial de uma grandeza vetorial é determinada pela sua direção e sentido. Uma direção pode ser caracterizada por um ângulo formado entre uma reta referencial e uma reta qualquer. Outras retas paralelas quaisquer que formem o mesmo ângulo com a referencial têm a mesma direção. O sentido admite duas possibilidades e determina a orientação da direção. Quando é dito que um corpo se move perpendicularmente para baixo, significa que sua direção é caracterizada pelo ângulo reto e um dos sentidos possíveis, para baixo.

Ao contrário da álgebra comum, a álgebra vetorial não lida só com números mas também com a orientação espacial, os vetores. Um vetor é caracterizado por um módulo (número não negativo), direção e sentido. 
$\mathrm{O}$ vetor zero é representado por $0=(0,0,0)$, cujos componentes são zero. Xenakis faz uma analogia com a geometria elementar e chama o vetor zero de origem das coordenadas. Um vetor com os elementos $(\mathrm{x} 1, \mathrm{x} 2, \mathrm{x} 3)$ será desse modo chamado de ponto $\mathrm{M}$ das coordenadas $(\mathrm{x} 1, \mathrm{x} 2, \mathrm{x} 3)$. Dois vetores serão ditos iguais se a seqüência que define ambos for a mesma: $X \mathrm{i}=Y \mathrm{i}$.

Uma seqüência de vetores é definida por um espaço vetor. Um espaço vetor possui, neste caso, três variáveis h, i e d; altura, intensidade e duração respectivamente. Um espaço vetor com três variáveis é designado por E3. Há casos mais simples e outros mais complexos em que o espaço vetor inclui menos ou mais variáveis. A delimitação de um espaço vetor depende dos objetivos do compositor. Aqui estamos tratando dos parâmetros básicos que um espaço vetor pode conter.

Com relação a E3, duas leis de composição são admitidas:

1. Adição. Se um vetor sonoro $X=(\mathrm{x} 1, \mathrm{x} 2, \mathrm{x} 3)$ e $Y=(\mathrm{y} 1, \mathrm{y} 2, \mathrm{y} 3)$, então

$X+Y=(\mathrm{x} 1+\mathrm{y} 1, \mathrm{x} 2+\mathrm{y} 2, \mathrm{x} 3+\mathrm{y} 3)$.

As seguintes propriedades são verificadas para a adição:

a. $X+Y=Y+X$ (comutativa);

b. $X+(Y+Z)=(X+Y)+Z$ (associativa);

c. Dados dois vetores $X$ e $Y$, há um único vetor $Z=(\mathrm{z} 1, \mathrm{z2}$, z3), tal que $X=Y+Z$. Temos zi $=$ xi - yi. $Z$, portanto, é a diferença de $X$ e $Y: Z=X-Y$.

A adição de um vetor com sua origem não acarreta diferença, é ele mesmo: $X+0=$ $0+X=X$; e cada vetor pode ser associado com seu negativo $(-X)$, e com seus elementos $(-\mathrm{x} 1,-\mathrm{x} 2,-\mathrm{x} 3)$, tal que $X+(-X)=0$. 


\subsubsection{Espaço Vetor Associado a Uma Grandeza Escalar}

Para erigir um espaço vetor adequado para a realização musical vamos considerar os conjuntos H (intervalos melódicos), I (intervalos dinâmicos), D (intervalos de tempo), e o conjunto $\mathfrak{R}$ (conjunto dos números reais). Os conjuntos H, I e D formam o Espaço Vetor E3, que possui três variáveis: h, i e d, altura, intensidade e duração respectivamente. Uma lei externa de composição, para cada conjunto, pode ser estabelecida junto ao conjunto $\Re$. Para cada $X \in E(H, I, D)$, há um $p \in \Re$, tal que

$$
\mathrm{pX}=(\mathrm{px} 1, \mathrm{px} 2, \mathrm{px} 3) \in \mathrm{E} .
$$

Verificamos as seguintes propriedades $(\mathrm{p}, \mathrm{q}) \in \mathfrak{R}$ :

c. $1 \cdot X=X$ (elemento neutro);

b. $\mathrm{p} \bullet(\mathrm{q} X)=(\mathrm{pq}) \bullet X($ associativa $)$

c. $(\mathrm{p}+\mathrm{q}) \cdot X=\mathrm{p} X+\mathrm{q} X$ e $\mathrm{p} \bullet(X+Y)=\mathrm{p} X+\mathrm{p} Y($ distributiva $)$

A lei externa acima é necessária pois precisamos de um valor numérico que oriente os vetores de uma seqüência. No tópico seguinte observaremos como se dá essa relação entre espaço vetor e correspondente numérico.

\subsubsection{Valoração numérica de um Espaço Vetor Sonoro}

Se não é possível encontrar um sistema de i-números a1, a2, a3, ai..., todos não nulos, tal que a1 $X 1+\mathrm{a} 2 X 2+\ldots+\mathrm{ai} X \mathbf{1}=0$, e na condição que os n-vetores $X 1, X 2, \ldots X \mathrm{n}$, do espaço vetor En não é nulo, então dizemos que estes vetores são "linearmente independentes"

Suponha que um espaço vetor En, do qual o n-ésimo elemento é 1, e os outros nulos. Esse vetor an é a n-ésima "unidade" vetor de En. Há então três unidades vetores de E3, por exemplo, $h, i, d$, que correspondem respectivamente aos conjuntos $H$ (alturas), $I$

\footnotetext{
${ }^{10}$ Equação linear - Uma equação linear é toda equação do tipo $\mathbf{a} 1 \mathbf{x} 1+\mathbf{a} 2 \times \mathbf{2}+\mathbf{a} 3 \mathbf{3} \mathbf{3}+\ldots \mathbf{a n x n}=\mathbf{b}$, onde $\mathbf{a} 1 \times 1$, a2x2, ..., anXn são os termos da equação; a1, a2, .., são números reais chamados coeficientes dos termos; b é um número real chamado termo independente; e x1, $\mathbf{x 2}, \mathbf{x 3}, \ldots, \mathbf{x n}$ são variáveis incógnitas.
} 
(intensidades), e $D$ (durações) respectivamente; e estes três vetores são linearmente independentes, para a relação $\mathrm{a} 1 h+\mathrm{a} 2 i+\mathrm{a} 3 \mathrm{~d}=0$, seqüência a1+a $2+\mathrm{a} 3=0$. Dessa maneira, para cada vetor $X=(\mathrm{x} 1, \mathrm{x} 2, \mathrm{x} 3)$ de $\mathrm{E} 3$ pode ser escrito $X=\mathrm{x} 1 h+\mathrm{x} 2 i+\mathrm{x} 3 d$. A proposição acima implica na condição que o espaço vetor E3 conterá somente três vetores linearmente independentes, não mais do que isto. A seqüência h, i, d, constitui a base de E3. Fazendo uma analogia com a geometria elementar, dizemos que $0 \mathrm{~h}, 0 \mathrm{i}, 0 \mathrm{~d}$ são eixos de coordenadas, as respectivas origens dos parâmetros e referências para os demais vetores. (Xenakis, 1992: 162)

\subsubsection{Multiplicidade Vetorial Linear}

Dizemos que um conjunto $\mathrm{V}$ de vetores de En, não nulo, constitui uma “multiplicidade vetorial linear"se possui as seguintes propriedades:

1. Se $X$ é um vetor de $V$, cada vetor a $X$ pertence também a $V$, seja qual for a grandeza escalar $a$.

2. Se $X$ e $Y$ são dois vetores de $\mathrm{V}, X+Y$ também pertencem a V. Deduzimos então que: a. toda multiplicidade vetorial linear contém o vetor 0 , tal que $0 \mathrm{X}=0$; e b. cada combinação linear a $1 X 1+\mathrm{a} 2 X 2+\ldots+$ ai $X 1$ de i vetores de $\mathrm{V}$ é um vetor de $\mathrm{V}$.

Como vimos cada evento sonoro pode ser representado como uma multiplicidade linear vetorial, tendo como base os três parâmetros acústicos básicos, alturas, intensidades e durações. Qualquer outro parâmetro acústico relacionado com qualquer outro coeficiente mais complexo deve ter como princípios aqueles determinados para os parâmetros básicos. A dimensão de $\mathrm{V}$ é portanto igual a três, neste caso particular do qual estamos tratando. As grandezas escalares não podem abranger quaisquer valores, tendo em vista os limiares perceptivos. Tal restrição, no entanto, não invalida os argumentos gerais propostos e suas conseqüentes aplicações.

Por exemplo, considere 0 a origem de uma seqüência de vetores de três termos com $0 h, 0 i, 0 d$, como referente e base para a construção de um espaço vetor com três variáveis. Vamos estabelecer para cada uma das variáveis as seguintes unidades: 


$$
\begin{aligned}
& \text { para } h, 1=\text { semitom; } \\
& \text { para } i, 1=10 \mathrm{Db} ; \\
& \text { para } d, 1=\text { segundo. }
\end{aligned}
$$

A origem 0 será escolhida arbitrariamente numa das escalas estabelecidas pela tradição, à maneira do zero num termômetro. Desse modo temos:

$$
\begin{aligned}
& \text { para } h, 0 \text { será em Dó3; } \\
& \text { para } i, 0 \text { será em } 50 \mathrm{Db} ; \\
& \text { para } d, 0 \text { será em } 10 ” ;
\end{aligned}
$$

$(\mathrm{Lá} 3=440 \mathrm{~Hz})$.

Estabelecidas a origem e a unidade para cada variável podemos ter vetores como:

$$
X 1=5 h-3 i+5 d,
$$

lemos, cinco semitons vezes Dó3; menos 3 vezes $10 \mathrm{Db}$; mais 5 vezes 1 segundo. A expressão resulta em um Fá3 com intensidade $(50$ - 30) de 20 decibéis e dada que a origem é 10" (já se passaram dez segundos) mais 5 segundos, na posição temporal de 15". Vamos determinar que um segundo corresponda a uma colcheia pontuada. Dessa maneira podemos então transcrever para a notação tradicional. Um outro exemplo é o vetor

$$
X 2=7 \mathrm{~h}+1 \mathrm{i}+5 \mathrm{~d}
$$

lemos sete semitons vezes Dó3; mais 10 decibéis; mais 5 vezes 1 segundo, 15". A expressão resulta em um Sol3, com intensidade $(50+10)$ de 60 decibéis na posição de 15”, a mesma de X1. Da mesma maneira que X1 podemos transcrever para a notação tradicional.

De acordo com as leis propostas para os vetores, ao somar X1 com X2 obtemos:

$$
X 1+X 2=(5+7) h+(1-3) i+(5-1) d,
$$


resultando na expressão vetorial $12 h-2 i+4 d$, que resulta num Dó4 com intensidade de 30 decibéis na posição temporal de 14 segundos. Da mesma maneira podemos verificar todas as proposições precedentes estabelecidas.

\subsubsection{Duração e Unidade de Tempo}

Para explicitar a diferença existente entre os conjuntos vetoriais ${ }^{11} \mathrm{H}$, I e D, altura, intensidade e duração respectivamente estruturados fora de sua ocorrência temporal, há um quarto conjunto vetorial T. A função do conjunto vetorial T é concatenar as diferentes ocorrências dos conjuntos sonoros no interior de uma composição. Isso significa que ao tomarmos três conjuntos sonoros A, B e C, representados pelos seus respectivos conjuntos de vetores, designados pelos três parâmetros acústicos fundamentais, obedecem leis internas de arregimentação temporal distintas entre os conjuntos sonoros. Tendo em vista a construção de uma peça musical com conjuntos sonoros distintos, é exigida uma unidade temporal que unifique todos, tornando maleável a arquitetura de uma peça em nível global.

Por exemplo, um conjunto sonoro A de vetores, com características próprias de alturas, dinâmicas e durações internas é confeccionado. Da mesma forma dois outros grupos B e C são confeccionados. Descartando os dados altura e intensidade, três conjuntos A, B e C, obedecem leis internas de duração, ou seja lei interna do conjunto vetorial D (durações), distintas entre eles. Observando os princípios que irão definir uma peça musical, através da combinação de diferentes eventos sonoros, é definido um dispositivo temporal, uma unidade de tempo, a fim de planificar os eventos. A designação do conjunto $\mathrm{T}$ (de estruturas no tempo) confere à obra a coesão necessária, uma vez que estamos tratando de conjuntos sonoros de características distintas.

$\mathrm{Na}$ terminologia de Xenakis há duas "álgebras"12, uma "fora-do-tempo" e outra “temporal". A primeira para conceber os conjuntos sonoros que a peça conterá, a

11 Diferenciamos conjunto vetorial de conjunto sonoro. O primeiro trata de seus respectivos vetores delimitados para um dado parâmetro. O segundo, conjunto sonoro, é qualquer conjunto particular de vetores sonoros dado um espaço vetor. Trataremos dos conjuntos sonoros adiante.

12 É válido dizer que o termo "álgebra” utilizado por Xenakis é um tanto arbitrário, já que tais "álgebras são nada mais que princípios ordenadores, dispositivos de coesão global. Podemos dizer que tal terminologia criada pelo compositor atende somente uma necessidade subjetiva do compositor, primando por uma certa 
delimitação de suas durações particulares. A segunda para organizar os conjuntos sonoros, dada suas durações particulares, na estrutura global de uma peça musical, de acordo com uma referência temporal que permita visualizar os conjuntos sonoros num plano geral. A função do conjunto vetorial T é permitir a correspondência do particular com o geral, sem a qual não há materialização. Tal correspondência admite então uma terceira "álgebra", aquela da ocorrência "no-tempo" que é exatamente a planificação dos conjuntos sonoros que irão definir a peça.

Assumindo um novo conjunto vetorial T, caracterizado pela ocorrência temporal global, nos leva a três novas proposições:

1. No estudo de uma entidade, o conjunto sonoro: os conjuntos assumidos para os três parâmetros acústicos possuem uma "estrutura fora-dotempo";

2. O estudo de outra entidade simples, tempo, possui uma "estrutura temporal"; e

3. A correspondência entre ambas as estruturas citadas possui uma "estrutura no-tempo".

\subsubsection{Estrutura Temporal}

Já sabemos como funciona a primeira proposição, investigada nos tópicos acima, caracterizada pelo conjunto D (durações) de um espaço vetor. Vamos seguir com a mesma cadeia de raciocínio assumida e passar gradativamente da segunda proposição para a terceira, definindo o caráter temporal em suas três instâncias.

Dado um conjunto de durações Di de um conjunto sonoro A de vetores podemos afirmar que são sucessivos se, e somente se

$$
\mathrm{D} 0{ }_{-} \mathrm{D} 1{ }_{-} \mathrm{D} 2{ }_{-}
$$

elegância semântica. Tal arbitrariedade é verificada em toda a teoria de Música Simbólica, cuja perspectiva lógica erige um paralelo semântico de caráter sonoro. 
A expressão acima significa que um vetor ocorre temporalmente um após o outro, finda suas respectivas durações. Não podemos esquecer que um conjunto de vetores tem uma origem, e que a mesma será deslocada em decorrência dos vetores. Se tivéssemos um acorde, caracterizado pela ocorrência simultânea de vários vetores num mesmo instante, o deslocamento seria nulo.

Para designar uma Estrutura Temporal (conjunto vetorial T) Xenakis recorre a uma lei interna que nada mais é que uma progressão aritmética $^{13}$ cuja razão é $\Delta$ t. Dado um conjunto sonoro A com $i$-durações específicas do seu conjunto de vetores $D$, e dado um conjunto numérico $\mathrm{X}$ com $j$-valores que caracterizam os $i$-vetores de $D$, temos a seguinte igualdade:

$$
\Delta \mathrm{i}=\Delta \mathrm{j}
$$

A igualdade é estabelecida para não confundir a origem 0 de um dado conjunto sonoro de vetores e sua relação com a origem 0 ' da peça como um todo. A origem 0 de um dado vetor de um conjunto sonoro indica o deslocamento do vetor em relação a ocorrência temporal do conjunto, a duração temporal do conjunto; e a origem 0' indica o deslocamento do conjunto sonoro no interior da peça, duração global da peça musical. São três os tipos de durações: i) duração do vetor, que obedece uma lei interna do conjunto D de vetores; ii) decorrência temporal do conjunto de vetores; constatação de que dado um número de vetores de $\mathrm{D}$, há duração específica do conjunto, dada a arregimentação dos vetores no conjunto; e iii) decorrência temporal do conjunto sonoro dentro da estrutural global, posicionamento de sua ocorrência na estrutura. Relacionando ii) com iii), ou seja, dada a duração do conjunto e seu respectivo posicionamento global obtemos a seguinte função ${ }^{14}$, caracterizada por ser uma P.A.:

$$
\operatorname{ti}(\mathrm{C})=\mathrm{a}+\Delta \mathrm{t} \mathrm{i}, \mathrm{com}
$$

\footnotetext{
${ }^{13}$ Progressão Aritmética - Uma seqüência é chamada de progressão aritmética (P.A.) se, e somente se, a diferença entre cada termo (a partir do segundo) e o seu termo precedente é constante.$$
\mathrm{a}(\mathrm{n})-\mathrm{a}(\mathrm{n}-1)=\mathbf{r}(\forall \mathrm{n}, \mathrm{n} \geq 2)
$$

${ }^{14}$ Para uma definição de função reportamos o leitor para o tópico Teoria dos Conjuntos na Introdução desta dissertação.
} 
$\mathrm{i}=\mathrm{n}^{\mathrm{o}}$ de vetores do conjunto sonoro;

$\mathrm{a}=$ valor numérico de cada vetor no interior do conjunto;

$\Delta \mathrm{t}=$ posicionamento desejado no interior de uma duração específica global, ou razão da P.A.

Por exemplo, vamos supor que a duração total de uma peça musical seja de 10 minutos. Tal peça tem um conjunto sonoro $C$, caracterizado por um conjunto D (durações) de vetores, caracterizados por uma lei interna que define a duração de 1 segundo para cada vetor. O valor "a" representa essa unidade que define a sucessão ou simultaneidade dos vetores no interior do conjunto. Se queremos que o conjunto se posicione num dado momento decorrentes 3 minutos no interior da peça, então $\Delta \mathrm{t}=3^{\prime}$.

Com este item concluímos a fundamentação da linguagem musical simbólica que permitirá a criação de uma peça no âmbito da teoria de Música Simbólica. O próximo item é uma extensão da linguagem e só pode ser compreendido em acordo com as proposições acima.

\subsubsection{Estruturas no Tempo: uma extensão da linguagem}

Como vimos a linguagem musical formal de Xenakis, apresentada acima, concebe um espaço lingüístico musical potencial, ao levar a capacidade de organização de sinais para um terreno abstrato diverso daquele que rege a tradição, a composição que tem como ponto de partida o espaço em branco da partitura. A linguagem é também funcional. Embora num primeiro momento não sugira maleabilidade, é pensada para sinais acústicos da perspectiva de grandes construções formais. Forma pensada de um plano perceptivo amplo, partindo de abstrações formais para chegar numa ressignificação perceptiva exponencial do sonoro . Neste tópico a linguagem é estendida no sentido de potencializar as realizações possíveis com parâmetros acústicos integrados, através da evolução no tempo por meio de funções e progressões de um ou mais parâmetros.

Dado um espaço vetor E3, com três variáveis distintas para altura, duração, e intensidade, respectivamente os conjuntos H, D e I, de vetores sonoros. Podemos observar 
nos tópicos acima que dado um conjunto de coeficientes de E3, este caracteriza o espaço vetor:

$$
\begin{aligned}
& \text { Se } X=(x 1, x 2, x 3) \text { e } \\
& E 3=(H, I, D), \text { então } \\
& X \cdot E 3=(x 1 h, x 2 i, x 3 d)
\end{aligned}
$$

sendo que na equação acima, h, i e d são as variáveis de seus respectivos conjuntos de vetores sonoros. Xenakis propõe que a relação acima também seja uma evolução temporal, e como tal, função do tempo. Assim, a relação se caracteriza da seguinte maneira:

$$
\begin{aligned}
& \text { Se } X(t)=(x 1(t), x 2(t), x 3(t)) \text { e } \\
& E 3(t)=(H(t), I(t), D(t)) \text { então } \\
& X E 3(t)=(x 1 h(t), x 2 i(t), x 3 d(t))
\end{aligned}
$$

Quando funções temporais, como descritas, são contínuas podemos obter coeficientes diferenciais tanto para o espaço vetor quanto para o conjunto $\mathrm{T}$, que caracteriza sua ocorrência temporal. Entendemos que o conjunto T (da ocorrência temporal), é uma estruturação mínima a fim de organizar as estruturações atemporais junto aos tempos decorrentes dos conjuntos sonoros e a peça como um todo. Mas essa não é a única possibilidade, Xenakis propõe que conjuntos sonoros podem ser estruturados de acordo com funções e progressões aritméticas. Se essas funções são contínuas, ou seja, cujos parâmetros são invariáveis no decorrer do tempo, podemos impor coeficientes diferenciais "d", de modo que um ou mais parâmetros variem temporalmente. Admitindo a possibilidade de coeficientes diferenciais, estabelecemos abaixo uma primeira relação.

Dado um espaço vetor E3, que possui três conjuntos de vetores sonoros H(alturas), $\mathrm{I}($ intensidades), e $\mathrm{D}$ (durações), um conjunto $\mathrm{X}$ de coeficientes reais e um conjunto $\mathrm{T}$, caracterizado por uma unidade temporal igual a $\Delta \mathrm{t}$, obtemos

$$
\frac{d X}{d t}=\frac{d H}{d t}+\frac{d I}{d t}+\frac{d D}{d t}
$$


Considerando a relação acima, de um espaço vetor com sua decorrência temporal, como um caso geral, é possível impor perturbações, em que os diferenciais causem variação de um ou mais parâmetros no tempo. Os casos particulares, que seguem conseqüentemente do primeiro, não são os únicos. Xenakis propões exemplos de funções, peculiarmente interessantes, demonstrando que há uma gama ampla capaz de gerar conjuntos sonoros acusticamente instigantes. Ao aventar tais possibilidades, o compositor grego consegue provar a potência da linguagem, a despeito de sua aparente complexidade e guiando-a para além de um mero propósito funcional. Os casos particulares abaixo investigam as possibilidades de variação para os parâmetros altura e duração, e suas respectivas combinações, descartando o parâmetro intensidade. Isso não significa que ele não possa ser variado temporalmente, apenas não foi tomado como exemplo. Vamos aos casos particulares, propostos pelo compositor, dos mais simples aos mais complexos.

$$
\text { I) } \quad \text { Para } \frac{d H}{d t}=0, \underline{\mathrm{H}=\mathrm{ch}} \text { e para } \frac{d D}{d t}=0, \mathrm{D}=\mathrm{cd} \text {. }
$$

A restrição acima significa que as alturas e durações das notas movimentam-se independentemente de sua ocorrência temporal. Se ch e cd forem diferentes de 0 , então as alturas e durações permanecem constantes durante a ocorrência temporal. Desconsiderando o timbre, podemos dizer que teremos uma certa nota localizada numa dada altura e com uma certa duração, sem qualquer variação. Se ch e cd forem iguais a 0 , então não há emissão de sinal, configurando silêncio.

$$
\text { II) Para } \frac{d H}{d t}=0, \mathrm{H}=\mathrm{ch} \mathrm{e} \frac{d D}{d t}=c d, \mathrm{D}=\mathrm{cdt}+\mathrm{k} \text {. }
$$

Se ch e cd forem diferentes de 0 obtemos a emissão de notas sucessivas, de altura e duração única. Se $c d=0$, então temos uma única nota, de altura e duração única. Por exemplo, para cada altura invariável, há uma duração definida por uma constante $\mathrm{K} \mathrm{e}$ sucessivas posições temporais. Equivale a dizer que são vários uníssonos. 
III) Para $\frac{d H}{d t}=c h, \mathrm{H}=\mathrm{cht}+\mathrm{k}, \mathrm{e} \frac{d D}{d t}=0, \mathrm{D}=\mathrm{cd}$,

Se $\operatorname{cd}<\mathcal{E}, \lim \mathcal{E}=0$, obtemos um glissando constante de altura e duração únicas. O limite apenas indica que caso ocorra um valor menor que zero então um valor padrão é adotado, já que a fórmula acima é designada apenas para valores maiores que zero. Se cd > 0 , então obtemos um glissando espesso e constante, ou seja, um acorde de freqüências variáveis e durações invariáveis.

$$
\text { IV) Para } \frac{d H}{d t}=c h, \underline{\mathrm{H}=\mathrm{cht}+\mathrm{k}}, \mathrm{e} \frac{d D}{d t}=c d, \mathrm{D}=\mathrm{cdt}+\mathrm{r}
$$

A progressão indica uma infinidade de alturas e durações, constantemente variadas ( $\mathrm{k}$ e r, respectivamente), caracterizando um acorde constantemente variável no decorrer do tempo.

$$
\text { V) Para } \frac{d H}{d t}=c h, \mathrm{H}=\mathrm{ch}+\mathrm{k}, \mathrm{e} \frac{d D}{d t}=f(t), \mathrm{D}=\mathrm{F}(\mathrm{t})
$$

Com a relação acima obtemos um acorde composto por uma infinidade de vetores, com alturas de variação constante e durações cujo comportamento obedece uma dada função. Xenakis apenas sugere que as durações sejam, neste caso, conseqüência de uma função, mas não oferece nenhum exemplo. Uma função pode tanto caracterizar durações constantes quanto variações de ordem complexa. Neste caso, as alturas variam de acordo com uma razão constante " $k$ ", conjuntamente com suas respectivas durações que variam em acordo com uma função.

VI) Para $\frac{d H}{d t}=f(t), \mathrm{H}=\mathrm{F}(\mathrm{t}), \mathrm{e} \frac{d D}{d t}=0, \mathrm{D}=\mathrm{cd}$ 
Se $\mathrm{cd}<\mathcal{E}, \lim \mathcal{E}=0$, obtemos um glissando delgado e variável. O limite apenas indica que caso ocorra um valor menor que zero, um valor padrão é adotado, já que a fórmula acima é designada apenas para valores maiores que zero. $\mathrm{Se} \mathrm{cd}>0$, então obtemos um acorde que contém uma infinidade de vetores, com durações iguais a cd, uma duração específica invariável, e alturas que variam em acordo com uma função hipotética. Um glissando espesso e variável.

Finalizando,

VI) Para $\frac{d H}{d t}=f(t), \underline{\mathrm{H}=\mathrm{F}(\mathrm{t})} \mathrm{e} \frac{d D}{d t}=f(t), \mathrm{\textrm {D } = \mathrm { F } ( \mathrm { t } )}$.

A relação acima indica uma infinidade de vetores, em que suas respectivas alturas e durações obedecem uma função distinta. A intenção de Xenakis é obter uma evolução cuja variabilidade dos parâmetros possa abarcar uma complexidade crescente.

As possibilidades descritas acima partem do caso mais simples, onde os parâmetros não variam, para então adicionar progressões aos parâmetros, concluindo com o caso mais complexo em que ambos os parâmetros obedeçam funções distintas. Através de funções e progressões é possível obter uma gama ampla de variações sonoras. É importante notar que nos exemplos acima o parâmetro intensidade não é contemplado. Supomos que da mesma maneira, o parâmetro possa ser variado conjuntamente, seja com um ou ambos os parâmetros já exemplificados. Xenakis vislumbra possibilidades de evolução de parâmetros num plano bidimensional. Planos tridimensionais como um espaço vetor E3, que contém três variáveis distintas, também são suscetíveis dos mesmos tipos de imposições estilísticas, no sentido de extrair da matéria sonora um máximo de variabilidade evolutiva, no interior de conjuntos sonoros.

O desenvolvimento de tais idéias ocorreu durante a segunda metade da década de 1950. Nesse período, a síntese e processamento de sinais sonoros em estúdios próprios, estavam em sua aurora, num estágio ainda embrionário. A proposta de uma linguagem musical formal por Xenakis só encontrariam terreno fértil à medida da evolução dos computadores. Muitas das operações que essa linguagem musical formal oferece têm um 
evidente caráter computacional. Inicialmente, veremos que na composição da peça Herma (1960-61) para piano solo, a potencialidade de tal linguagem ainda é reduzida. Concluímos acima a exposição da linguagem musical formal assim como concebida por Xenakis. A seguir realizaremos uma investigação da criação da peça Herma, que engloba o nível médio citado inicialmente, aquele da construção dos conjuntos sonoros e construção da peça a partir de seus esquemas lógicos subseqüentes.

\subsection{Herma: Uma Estrutura Hors-Temps}

A peça para piano solo, Herma (1960-61), é a primeira tentativa de Xenakis em direção a formalização musical fundamentada em sua teoria de Música Simbólica. Sua estréia mundial se deu em 2 de fevereiro de 1962, por M.Y.Takahashi, para quem a peça foi dedicada.

Embora a peça não abranja todos os aspectos da linguagem musical formal, como descrita acima, fundamenta-se exclusivamente nela. Vamos observar algumas características da peça, primeiramente do ponto de vista da linguagem, para então analisarmos seus aspectos formais.

\subsubsection{A Linguagem Musical Formal Aplicada a Herma}

Da perspectiva da linguagem musical formal estabelecida por Xenakis podemos verificar as seguintes particularidades:

I. os elementos sonoros da peça são as teclas de um piano, e suas possibilidades por meios de pedais e interpretação, caracterizam o timbre da peça. Há portanto um único timbre, invariável, não submetido à nenhuma estratégia a não ser aquela do próprio compositor;

II. O espaço vetor é igual a 1, e contém apenas um conjunto H (alturas), de vetores sonoros. Os parâmetros duração e intensidade foram abordados arbitrariamente pelo compositor, fora do escopo da linguagem. Portanto seu espaço vetor pode ser descrito como $\mathrm{E} 1=(\mathrm{H})$; 
III. Como a elaboração da peça descarta os parâmetros intensidade e duração, não é possível observar nenhuma função aplicada ao conjunto $\mathrm{T}$ (conjunto temporal); e

IV. O compositor remete a ordenação das alturas, ou seja, a ordem em que se sucedem no tempo, através de uma distribuição estocástica irrelevante. Tal distribuição foi intencionada de modo a assegurar a peculiaridade dos conjuntos de elementos sonoros, desvinculando os mesmos de qualquer contorno melódico ou harmônico.

Nossa análise consistirá apenas dos itens I e II acima, tendo em vista a linguagem, contida nos próximos tópicos. Trataremos dos parâmetros intensidade e duração na análise da organização formal da peça. Por uma escolha do compositor, tais parâmetros foram abordados somente na apresentação dos conjuntos, trata-se exclusivamente de uma abordagem interpretativa para a execução da obra. Também não investigaremos a distribuição estocástica, pois de acordo com o próprio compositor

“... podemos demonstrar os sons de um conjunto no piano [...] tocando um som após outro. Em que ordem? Se tocarmos os sons cromaticamente, ascendentemente ou descendentemente, estaríamos seguindo uma regra muito estrita. Se queremos que os sons sejam livres, então não devem seguir nenhuma lei melódica, devem ser independentes uns dos outros. Temos que toca-los randomicamente. Em outras palavras, para demonstrar os elementos de um conjunto usamos o método estocástico. A idéia básica de Herma não tem nada a ver com a abordagem estocástica - a estocástica é necessária apenas para demonstrar os elementos dos conjuntos." (Xenakis apud Varga, 1996: 84-85)

As notas dos conjuntos são apresentadas ao longo da execução da peça como se fossem escolhidas num sorteio. Imaginemos que as notas de um conjunto são bolas devidamente identificadas com suas respectivas alturas, colocadas numa urna e sorteadas uma-a-uma até que fique vazia. A seqüência obtida através do sorteio é a ordem de aparição das notas na partitura.

\subsubsection{Designação dos Conjuntos Sonoros de Herma}

Como afirmamos acima os conjuntos sonoros de Herma são caracterizados pelos elementos sonoros teclas de um piano e por um espaço vetor E1 que contém apenas o conjunto de vetores sonoro H (alturas). Não há muito a ser dito acerca das teclas de um piano, uma vez que o timbre do piano permanece invariável, recorrendo apenas ao uso de 
suas possibilidades inerentes ao uso de pedais, mas trataremos deste assunto adiante pois não afetam a compreensão da elaboração primária dos conjuntos. Trataremos aqui somente da faixa que cobre o registro total de alturas de um piano. Um piano contém oito oitavas de alturas, sendo que as distâncias entre uma tecla e outra obedecem o padrão do sistema temperado caracterizado por tons e semitons. As doze notas por oitava são respectivamente: Lá, Lá\#, Si, Dó, Dó\#, Ré, Ré\#, Mi, Fá, Fá\#, Sol, Sol\#.

Xenakis representa as oitavas por meio de números naturais, da oitava mais grave (1) à mais aguda (6) obtemos um total de oito números naturais indicadores: $(-1,0,1,2,3$, $4,5,6)$.

O conjunto R representa a totalidade das teclas do piano. Os conjuntos $\mathrm{A}, \mathrm{B}$ e C são subconjuntos de R. Segundo Santana (2001) a análise da obra demonstra liberdades que extrapolam a exatidão dos cálculos privilegiando a coerência na escuta. Na classe referencial R, ao invés de 428 alturas que constituem o conjunto o compositor estende o número para 618. Em relação às classes $\mathrm{A}, \mathrm{B}$ e $\mathrm{C}$ e suas respectivas negações apresentam elementos comuns não correspondendo aos cálculos obtidos (Santana, 2001).

Os Conjuntos A, B e C foram confeccionados de maneira que pudessem ser submetidos a operações entre eles. As operações são aquelas das teoria dos conjuntos: intersecção $\cap$, união $\cup$ e complemento $\bar{X}$; sendo a primeira para designar somente os elementos comuns entre os conjuntos; a segunda para designar além dos elementos em comum, aqueles que pertencem somente a um e a outro; e o terceiro para designar a exclusão do conjunto universo todos os elementos do conjunto complemento.

\subsubsection{A Arquitetura Global de Herma}

Xenakis recorre a uma função de Boole ${ }^{15}$ para os conjuntos de alturas, cuja variável é “h”, uma expressão que extraia o número máximo de operações possíveis com 3

\footnotetext{
${ }^{15}$ O matemático inglês George Boole (1815 - 1864) publicou em 1854 a obra "An Investigation of Laws of Thought" onde descreveu um sistema algébrico mais tarde denominado de Álgebra de Boole. A álgebra de boole admite as propriedades comutativa, associativa, distributiva, elemento neutro e complemento. Os símbolos da álgebra booleana são $(+)$ para designar união de conjntos, $(\bullet)$ para intersecção de conjuntos e
} 
conjuntos dados, no caso estudado 'A', 'B' e 'C'. As operações primárias que podemos obter utilizando apenas os operadores $(\bullet),(\bar{X})$ e os três conjuntos 'A', 'B', e 'C' por expressão, são:

1. $\mathrm{A} \bullet \mathrm{B} \bullet \mathrm{C}=2$ operações de interseção;

2. A • B $\bullet \bar{C}=3$ operações, uma de intersecção e uma de complementaridade;

3. A $\cdot \bar{B} \cdot \mathrm{C}=3$ operações, duas de intersecção e uma de complementaridade;

4. A $\cdot \bar{B} \cdot \bar{C}=4$ operações, duas de intersecção e duas de complementaridade;

5. $\bar{A} \cdot \mathrm{B} \cdot \mathrm{C}=3$ operações, duas de intersecção e uma de complementaridade;

6. $\bar{A} \cdot \mathrm{B} \cdot \bar{C}=4$ operações, duas de intersecção e duas de complementaridade;

7. $\bar{A} \cdot \bar{B} \cdot \mathrm{C}=4$ operações, duas de intersecção e duas de complementaridade;

8. $\bar{A} \cdot \bar{B} \cdot \bar{C}=5$ operações, duas de intersecção e três de complementaridade.

Com a intenção de obter um máximo de operações utilizando os três operadores $(+)$ união, (•) intersecção e $(\bar{X})$ complementaridade, Xenakis recorre a uma expressão booleana que fornece o número de operações possíveis com três conjuntos:

$$
3 n \times 2^{n-2}-1
$$

Como o total do número de conjuntos é igual a três, ou seja, 'A', 'B', e 'C'. Então n=3. Deste modo o número de operações que podemos obter com três conjuntos e três operadores booleanos é igual a 17 , já que:

$$
3 * 3 \times 2^{3-2}-1=17
$$

$(\bar{X})$ um traço acima da letra maiúscula que designa o conjunto, para indicar complementaridade ou seja todos os elementos do conjunto universo excetuando aqueles de $\bar{X}$. 
Este número 17, obtido pela expressão acima indica que o número de operações possíveis é igual a dezessete, incluindo os três operadores e os três conjuntos e suas repetições. Portanto a função booleana com 17 operações, uma vez que já obtemos a lista de operações envolvendo apenas dois operadores e os conjuntos, e agora levando em consideração o operador (+) união é:

$$
\mathrm{F}=\mathrm{A} \cdot \mathrm{B} \cdot \mathrm{C}+\mathrm{A} \cdot \bar{B} \cdot \bar{C}+\bar{A} \cdot \mathrm{B} \cdot \bar{C}+\bar{A} \cdot \bar{B} \cdot \mathrm{C}
$$

Podemos notar que a expressão acima consiste das operações 1, 4, 6 e 7 da lista acima. Se somarmos suas respectivas quantidades de operações obtemos um total de 14 operações, adicionando mais três operadores de adição $(+)$ obtemos um total de 17 operações.

É interessante notar que a expressão acima pode ser simplificada, e assim obtermos uma outra expressão equivalente, com 10 operações ao invés de 17. Basta enxergarmos da seguinte maneira, dividimos a função acima em duas partes: i) $\mathrm{A} \bullet \mathrm{B} \bullet \mathrm{C}+\mathrm{A} \bullet \bar{B} \cdot \bar{C}$ e i) $\bar{A} \bullet \mathrm{B} \cdot \bar{C}+\bar{A} \cdot \bar{B} \cdot \mathrm{C}$. Primeiramente simplificamos ii):

$$
\mathrm{A} \cdot \mathrm{B} \cdot \mathrm{C}+\mathrm{A} \cdot \bar{B} \cdot \bar{C}=(\mathrm{A} \cdot \mathrm{B}+\bar{A} \cdot \bar{B}) \cdot \mathrm{C}
$$

Simplificando ii):

$$
\bar{A} \cdot \mathrm{B} \cdot \bar{C}+\bar{A} \cdot \bar{B} \cdot \mathrm{C}=(\overline{A \cdot B+\overline{A \cdot B}}) \cdot \bar{C}
$$

Unindo a expressão i) com ii) obtemos:

$$
(\mathrm{A} \bullet \mathrm{B}+\bar{A} \bullet \bar{B}) \bullet \mathrm{C}+(\overline{A \bullet B+\overline{A \bullet B}}) \cdot \bar{C}
$$




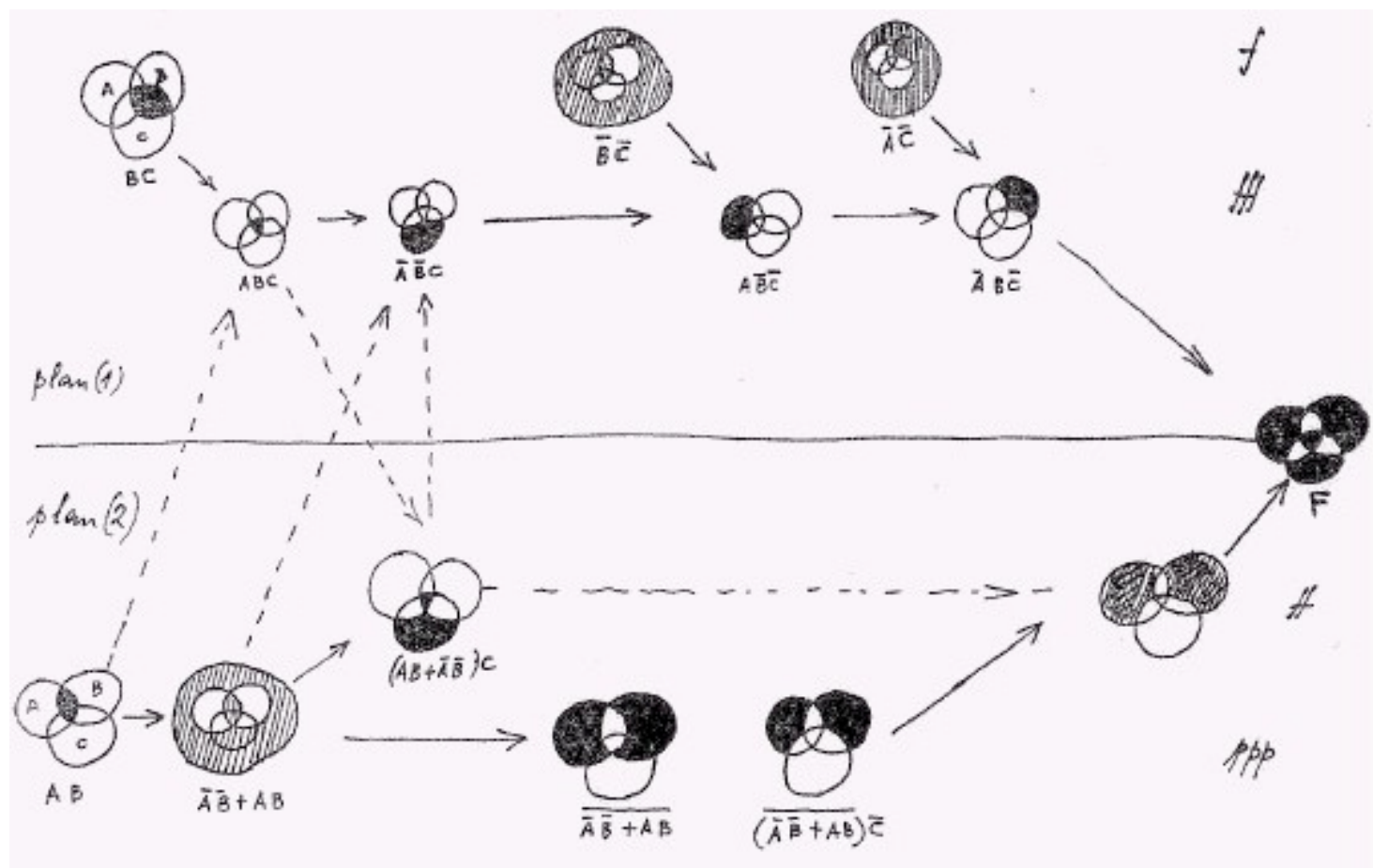

Fig 4.1 - Plano de Construção de Herma. O Plano 1 na figura corresponde a i) e o Plano 2 corresponde a ii) (Xenakis, 1962).

\subsubsection{Transcrição e Gravação}

A cadeia de raciocínio acima e sua respectiva concretização sonora nos leva à forma de Herma: do conjunto universo ' $R$ ' até a última expressão caracterizada pela função booleana com um máximo de operações lógicas. A partitura ${ }^{16}$ da peça contém 20 páginas, sendo que a última contém a expressão mais complexa. A gravação ${ }^{17}$ tem uma duração aproximada de 7’23”, culminando com a expressão lógica mais complexa numa apresentação dinâmica explosiva.

Ao longo da peça são apresentados os conjuntos básicos, passando pelas operações mais simples até a explosão final com a expressão máxima de 10 operações. Os conjuntos são apresentados de duas maneiras: densa e linear; na apresentação densa há uma aglomeração de notas, muito próximas ou executadas simultaneamente, já na linear as notas são executadas esparsamente e quase nunca simultaneamente. As

\footnotetext{
${ }^{16}$ Herma - Boosey \& Hawkes

${ }^{17}$ Herma, na interpretação de Claude Helffer. Xenakis Chamber Music (1955-1990), Disco 1 - Faixa 4. Selo Montaigne Näive.
} 
apresentações densas são caracterizadas por dinâmicas mais expressivas e as lineares por dinâmicas mais suaves. As mesmas são apresentadas por vezes com e sem a utilização de pedal, ou seja, há seções onde as notas são sustentadas e outras em que elas apresentam durações mais curtas.

Xenakis inicia a peça apresentando o conjunto universo ' $R$ ' até o início da página 3 da partitura, com uma duração aproximada de 35". Quando a apresentação de ' $R$ ' culmina numa aglomeração de notas, o conjunto A surge então linearmente, juntamente com uma seção densa, até 1'35'. À apresentação de cada conjunto 'A', 'B' e 'C' seguem, respectivamente, seus complementos $\bar{A}, \bar{B} \mathrm{e} \bar{C}$. Após uma pausa, se inicia a apresentação do complemento de $\bar{A}$, de maneira densa, até 1'57' quando então se inicia o conjunto B. O conjunto B é apresentado linearmente e também é seguido por uma seção densa até 2'20" quando se inicia seu complemento $\bar{B}$ até 3'12”, pág.9 da partitura. Após uma pausa o conjunto $\mathrm{C}$ se inicia de maneira densa e linearmente respectivamente, até 3'33" quando após uma pausa se inicia o seu complemento de maneira densa até 4'05". 


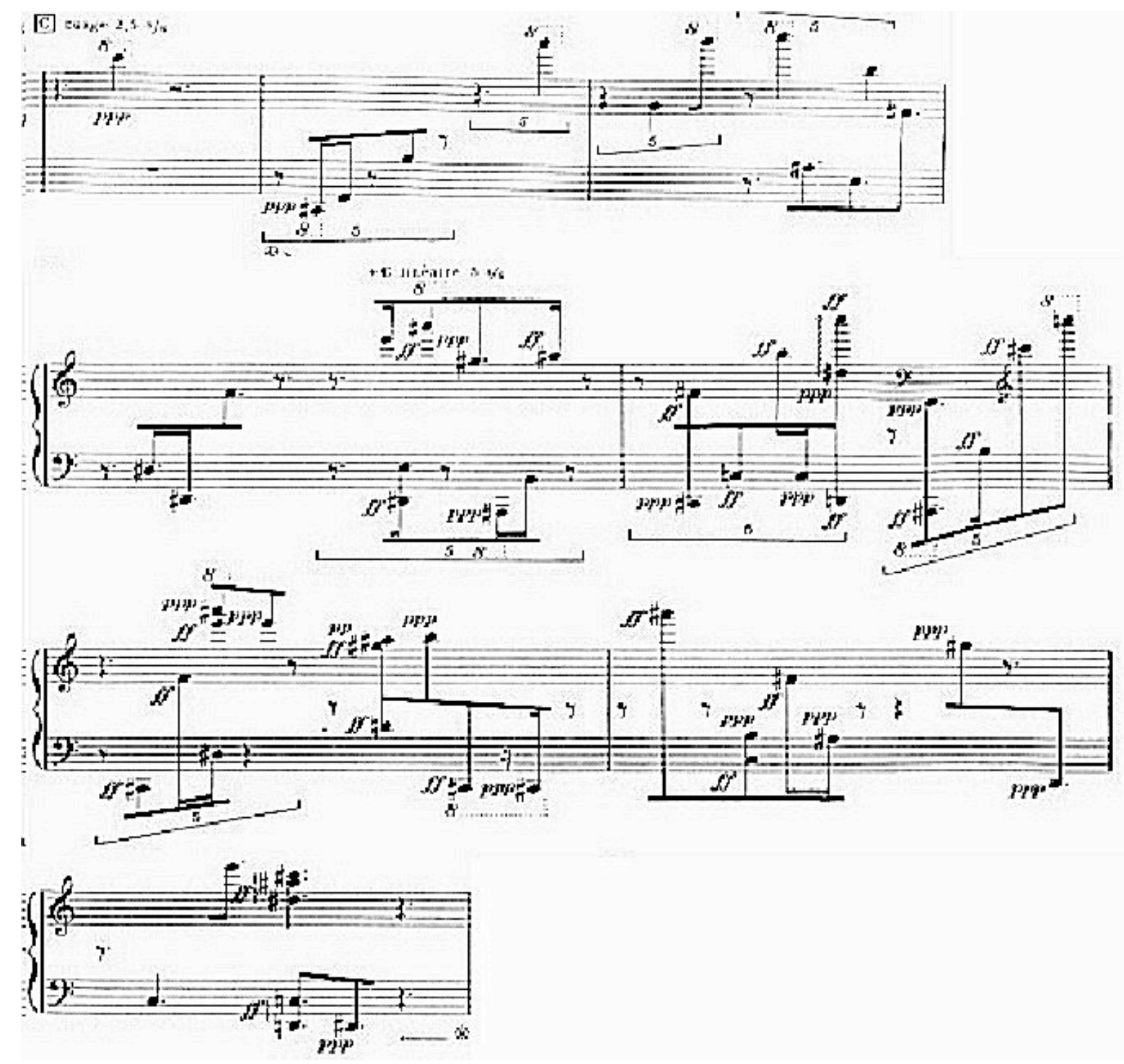

Fig 4.2 - Conjunto C como apresentado na partitura de Herma.

Apresentados os conjuntos universo e seus respectivos subconjuntos que caracterizam a obra se inicia então as operações com os mesmos, dos mais simples até a finalização da peça com a expressão lógica mais complexa. Como podemos notar a duração da peça até aqui é de pouco mais de 4', abrangendo 11 páginas da partitura, a maior parte da peça portanto. Apesar da crescente complexidade da peça, as operações com os conjuntos apenas se iniciam após os 4'. Quanto maior a complexidade 
percebemos uma redução da execução e do espaço na partitura. A parte central da obra caracterizada pela apresentação de expressões lógicas de crescente complexidade se inicia em aproximadamente 4'20” com a expressão A • B, com apenas uma operação, até 6'55", quando após uma longa pausa, se inicia a expressão com 10 operações. Essa porção central inclui tanto expressões com dois conjuntos, com um máximo de três operações, até operações com três conjuntos, com um máximo de 4 operações, além das duas partes i) e ii) da expressão mais complexa. A seção dura aproximadamente 2'35" e vai da página 12 à 18 da partitura, 6 páginas portanto. Aqui também notamos diferentes densidades e linearidades, sem seguir um critério formal específico a não ser aquele arbitrário do próprio compositor. Também há um dinamismo alternante entre seções suaves com outras mais agressivas.

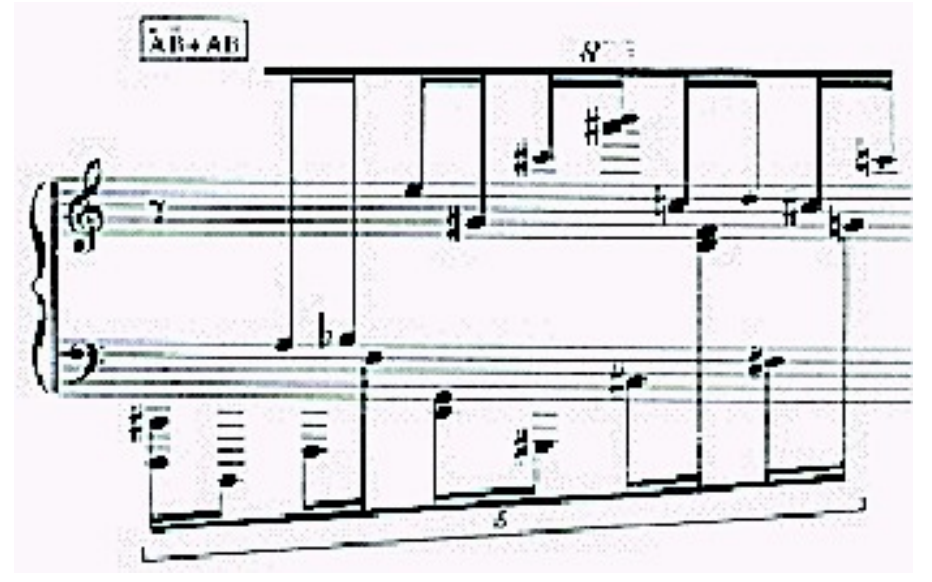

Fig 4.3 - Exemplo de operação com conjuntos $\bar{A} \bar{B}+\mathrm{A}$ B

A peça conclui na página 20, toda dedicada à expressão mais complexa com 10 operações. Esta última porção, a de menor duração, inicia em 6'55" e termina em 7'05' quando soa as últimas notas simultâneas até cessarem em 7'23'. A expressão final é apresentada de maneira densa e com dinâmica extremamente agressiva. 

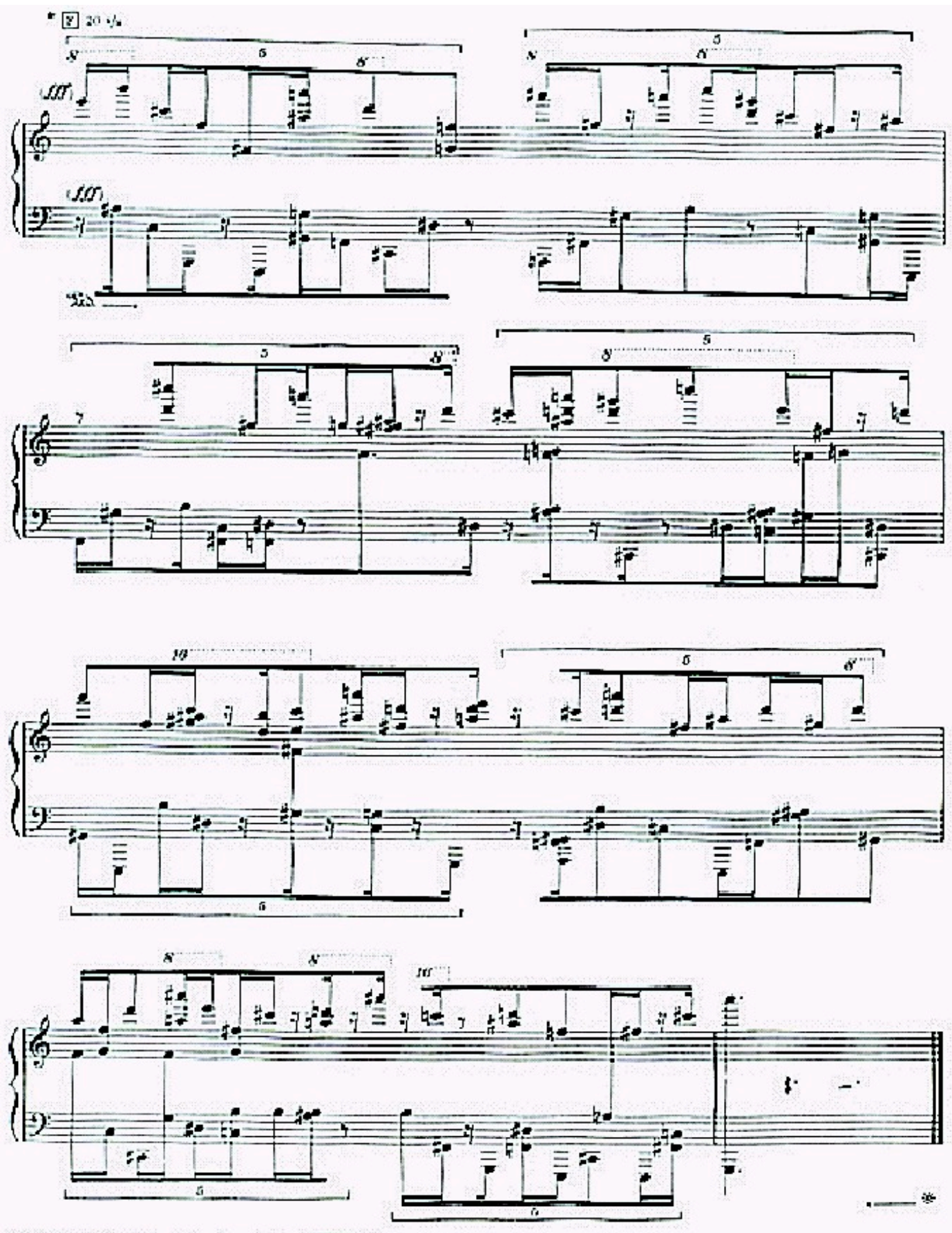

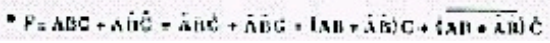

Fig 4.4 - Página final de Herma, a expressão mais complexa. 


\subsubsection{Perspectiva da Percepção}

Embora Herma seja caracterizada pelo seu rigor formal, fundamentada nos princípios da lógica clássica, poucas vezes a escuta é capaz de compreender e apreender a potencialidade de tais expressões lógicas.

A intenção de Xenakis ao compor a peça era apresentar ao ouvinte conjuntos discretos de alturas dado um conjunto universo, sem relações com escalas tradicionais, e suas respectivas relações lógicas. No entanto a escuta num primeiro momento tende a guiar-se por meio das linearidades e densidades, bem como a suas dinâmicas, que não obedecem nenhuma estratégia lógica, abordada de maneira intuitiva pelo compositor. A disposição estocástica das notas também pouco contribui para que o ouvinte tenha uma orientação particular acerca das distâncias entre as alturas que caracterizam os conjuntos. Não há nenhum critério oferecido pelo compositor acerca das durações, tanto dos elementos como dos conjuntos, também abordadas intuitivamente. O ouvinte tem a primeira parte da peça para se familiarizar com os conjuntos, muitas vezes pouco distinguíveis, não há uma característica objetiva de cada conjunto que permita o ouvinte guiar-se pelas suas particularidades.

É notável que a partir da apresentação das expressões algébricas dos conjuntos há uma redução temporal, quanto maior a expressão menor é a duração sonora. A duração da primeira seção é notavelmente maior do que a segunda, quando ocorrem as

expressões relativas aos conjuntos. A terceira seção é a de menor duração caracterizada pela ocorrência da expressão de maior complexidade. 


\section{CONCLUSÃO}

No prefácio de sua obra teórica, quando pela primeira vez publicada em 1962, Iannis Xenakis escreveu o seguinte acerca da beleza musical:

“... a qualificação "bonito" ou "feio" não faz sentido para o sonoro nem pela música dele derivada; é a quantidade de inteligência carregada pelo sonoro que deveria ser o critério de validade de uma música em particular" (Xenakis, 1992:ix)

Afinal de contas o que é música para Xenakis? De acordo com o compositor esta pode ser definida em seis proposições:

1. É uma sorte de comportamento para quem a pensa e faz;

2. É um pleroma individual, uma realização;

3. É normativa, isto é, inconscientemente é um modelo para ser ou fazer por condução simpática;

4. É catalítica, sua mera presença permite transformações internas psíquicas ou mentais do mesmo modo que a bola de cristal do hipnotizador;

5. É a brincadeira gratuita de uma criança;

6. É um ascetismo místico (mas ateísta). Conseqüentemente expressões de tristeza, alegria, amor e situações dramáticas são apenas limitadas instâncias particulares. (Xenakis, 1992:181).

Podemos deduzir das palavras de Xenakis que sua música não se traduz pelo êxtase superficial imediato que nos traz quando ouvimos uma melodia de Mozart, mas é aquele da ascese pitagórica que ao som da lira órfica apreende a totalidade da realidade e a expressa em números. Se para os pitagóricos o mundo podia ser inferido a partir das proporções das cordas da lira para Xenakis o sonoro artificialmente regido traz em sua opulência a ressonância do mundo. Assim como para os pitagóricos a medida do mundo correspondia à sua própria evolução física e matemática, Xenakis também lança o olhar para os desenvolvimentos científicos e tecnológicos de sua própria época. Traz no escopo de sua música o abalo causado pelo renascimento da lógica no séc. XIX, pelo surgimento da física quântica bem como toda a teoria das probabilidades que daria a fundamentação destas novas descobertas físicas. Faz com que sua música ressoe os novos paradoxos suscitados 
pelas ciências. A música de Xenakis é a irreversibilidade dos fenômenos traduzida pela Segunda Lei da Termodinâmica, é o espanto causado pela imprevisibilidade do universo quântico, pelas incipientes sonoridades possibilitadas não mais regidas pela mecânica clássica. Anos após suas primeiras experiências musicais Xenakis estava convicto de seu posicionamento estético:

"E fiquei convencido - e mesmo hoje eu permaneço - que alguém pode ativar universalidade, não através da religião, não através das emoções ou tradição, mas através das ciências. Através do modo científico de pensar. Até mesmo com isso, alguém pode chegar aqui sem idéias gerais, pontos de partida. O pensamento científico é apenas um meio com que realizo minhas idéias, que não são de origem científica, estas idéias nascem da intuição, de algum tipo de visão. Nada disso estava claro para mim, mas eu trabalhei instintivamente nessa direção" (Xenakis apud Varga, 1996:47).

Para dar um exemplo grosseiro Xenakis percorre o caminho inverso da ficção científica clássica que busca dar soluções e fazer previsões para as ciências, ele vai até as ciências e trás novos objetos estéticos, música cujas soluções e novos questionamentos estão interligados com a abordagem científica. Isso não significa que sua música fosse legítima num primeiro momento mas legitimada com o surgimento de toda uma nova geração de compositores. Tais compositores deram origem às composições algorítmicas e à expansão da paleta de cores sintéticas da música eletroacústica através da síntese granular. Compositores como o americano Curtis Roads autor da obra teórica Microsound (2001), escreveu um tratado acerca das partículas sonoras e suas vastas possibilidades em terreno digital, bem como suas composições que reanimam as sonoridades granulares partindo de novas complexidades formais. Outro herdeiro direto das propostas de Xenakis é o italiano Agostino Di Scipio cujas pesquisas do trabalho de Xenakis oferecem uma visão original e novos pontos de partida. Suas composições são caracterizadas pela utilização de granulações recursivas e interativas com o meio ambiente de uma perspectiva sonora ecológica (Di Scipio, 2002: 22-32).

Sem contar que toda uma nova geração de artistas que extrapolam o meio acadêmico têm em Xenakis um avô longínquo. Estamos falando de artistas como o japonês Masamo Akita (conhecido como Merzbow) reconhecido pela sua intensa produção de obras violentamente ruidosas, e o finlandês Mika Väinio um dos expoentes da corrente glitch, que trabalha com materiais sonoros decorrentes de micro falhas digitais. Estes os mais 
conhecidos pois atualmente há todo um universo de produções independentes que divulga obras descartáveis em compact discs graváveis, todas baseadas no microsonoro, espalhadas pelos quatro cantos de mundo e representadas por uma infinidade de pequenas gravadoras. De modo que o legado de Xenakis irá, sem sombra de dúvidas, se prolongar por muitas e muitas décadas e num futuro próximo suas obras poderão ganhar o status de "clássicos".

A abordagem matemática de Xenakis nem sempre veio desacompanhada de estéticas similares em outras artes como a literatura por exemplo. Paralelamente ao mesmo período em que Xenakis realizava suas primeiras obras, especialmente no início da década de 1960, um grupo de escritores se reunia em Paris para propor novas estruturações da escrita com base matemática. O Oulipo (ateliê de literatura potencial) pregava a utilização de regras para produzir infinitos textos. O escritor Raymond Queneau teria afirmado certa vez que o escritor que relega sua escrita livremente à subjetividade é tão escravo quanto aquele que cria as próprias regras, pois é escravo de regras que desconhece. Se trocarmos a palavra escritor por compositor teremos uma definição precisa de Xenakis enquanto criador já que sua liberdade compositiva residia justamente na invenção das próprias regras geradoras de peças musicais. No caso das artes plásticas é o próprio Xenakis que oferece como exemplo Michel Philippot, compositor e pintor, que aplicou pela primeira vez o cálculo de probabilidades em suas pinturas (Xenakis, 1992: 39).

Esta dissertação intitulada rízomata, palavra grega para conjunto de raízes, teve como objetivo expor uma introdução às raízes da música de Xenakis. Preferimos muitas vezes oferecer uma abordagem intuitiva de suas composições tendo em vista um guia de escuta de suas peças iniciais e sugestão para todo o restante de suas obras. Se muitas vezes falhamos numa exposição matemática mais rigorosa, esta não era a intenção, e sim expor os fundamentos, um estudo de agrimensura que tem como conseqüência artefatos sonoros. Nosso estudo musicológico jamais ousou esperar que o compositor que por ventura leia esta exposição apreenda receitas para compor exatamente como Xenakis. Muito menos esperamos que o musicólogo se convença da matemática de Xenakis como último e único fim estético. Mais do que isso esperamos que compositores e musicólogos possam tomar contato com a abordagem inovadora de Xenakis, com seu diálogo insistente com as ciências de nossa época. Apreciar a estética de Xenakis não exclui que o façamos sem ir 
contra ele, aliás atitude necessária e enriquecedora no interior de qualquer estética, combustão criativa. Além do mais é também tradição que as coisas mudem ao longo do desenvolvimento cultural da humanidade. Não colocamos a música de Xenakis como instância histórica conseqüente de um processo, descartamos o imperativo histórico para compreendê-lo, esperamos que sua música possa ser apreendida em sua imanência. Para compreender e apreciar Bach não necessitamos apenas de sua localização na história, e é importante ressaltar que até mesmo Bach não está livre de interpretações de cunho científico, há matemática ali também. 


\section{REFERÊNCIAS BIBLIOGRÁFICAS}

ARSENAULT, Linda. M. Iannis Xenakis's Achorripsis: The Matrix Game. Computer Music Journal, 26:1. Massachussetts: Massachussetts Institute of Technology, 2002.

BOIS, Mario. Xenakis: The Man and his Music. London: Boosey \& Hawkes, 1967.

BOREL, Emile. Probabilidade E Certeza. São Paulo: Difusão Européia do Livro, 1956.

CHADABE, Joel. Electric Sound: The Past and Promise of Electronic Music. New Upper Saddle River: Prentice Hall, 1997.

CHAUÍ, Marilena. Introdução à história da Filosofia: dos pré-socráticos a Aristóteles, volume 1. 2. ed. São Paulo: Companhia das Letras, 2005.

DE LIO, T. Diamorphoses by Iannis Xenakis. In: Risset, Jean-Claude. Electroacoustic music: analyctical perspectives. Westport: Greenwood Press, 2002.p. 41-57.

DI SCIPIO, Agostino. The Problem of $2^{\text {nd }}$ - order Sonorities in Xenakis's Electroacoustic Music. Organized Sound 2(3), 1997.

DI SCIPIO, Agostino. Compositional Models in Xenaki's Electroacoustic Music. Perspectives of New Music 36(2), 1998.

FELLER, William. Introdução À Teoria Da Probabilidade E Suas Aplicações: Parte 1Espaços Amostrais Discretos. São Paulo: Edgard Blücher , 1976.

GRIFFITHS, P. A. Música Moderna. Reimpressão. Rio de Janeiro: Jorge Zahar, 1993.

HARLEY, James. The Electroacoustique Music of Iannis Xenakis. Computer Music Journal. No26:1. Spring 2002. Massachussetts: Massachussetts Institute of Technology, 2002.

KELLER, Damián e FERNEYHOUGH, Brian. Analysis by Modeling: Xenakis's ST/10-1 080262. Journal of New Music Research, Stanford, v. 33, n. 2, p. 161-171, 2004.

DA COSTA, Newton C. A. e KRAUSE, Décio. Lógica. Santa Catarina: Grupo de Lógica e Fundamentos da Ciência, 2005.

MALT, M. Trois aspects de formalization musicale dans “Achorripsis” de Iannis Xenakis. Paris: Mémorie DEA: Musique et musicologie du XX ème siècle: E.H.E.S.S., 1991. 
MATOSSIAN, Nouritza. Xenakis. London: Kahn \& Averill, 1986.

MILIES, César Polcino Milies e Coelho, Sônia Coelho. Números: Uma Introdução à Matemática. 3. ed. São Paulo:Edusp, 1998.

MORTARI, César A. Introdução à Lógica. São Paulo: Editora Unesp, 2001.

PINTO, Manuel da Costa. Dossiê. Cult-Revista Brasileira de Literatura, Rio de Janeiro, n. 52, p.2, 2001.

ROEDERER, Juan G. Introdução à Física e Psicofísica da Música. São Paulo: Edusp, 2005.

ROADS, Curtis. Microsound. Massachussets: MIT Press, 2001.

Solomos, M. Les Anasteria de Xenakis: Cntinuité et Discontinuité Historique. In: Continu et discontnu dans l'ouvre de Iannis Xenakis. França: Université Montpellier 3, 2003.

TOMÉ, Tânia e Oliveira, Mario José. Dinâmica Estocástica e Irreversibilidade. São Paulo: Edusp, 2001.

VARGA, Báling András. Conversations with Iannis Xenakis. London: Faber \& Faber, 1996.

XENAKIS, Iannis. Arts/Sciences - Alloys. Stuyvesant: Pendragon Press, 1985.

1986.

. Espace musical, espace scientifique. Courrie de l'UNESCO 4,

Formalized Music: thought and mathematics in composition. (HARMONOLOGIA SERIES No. 6).Revised edition. Stuyvesant: Pendragon Press, 1992.

.Herma. Boosey \& Hawkes, 1962.

.Keléutha- Ecrits. Paris: L’Arche Editeur, 1994.

.Metastaseis. Boosey \& Hawkes, 1967.

Musique. Arquitecture. Collection "Mutations- Orientations"

Vol.11, edited by M.Ragon, Tournai (Belgium) 1971; 2. expanded and revised edition 1976 .

.Musiques Formelles. Paris: Éditions Richard-Musse, 1962. 
- Musique et Orginalité. Paris: Nouvelles éditions Séguier, Carrer musique, 1996.

Xenakis on Xenakis. Perspectives of New Music. Volume 25.

No1-2. Winter-Summer. Seattle: University of Washington, 1987.

ZAPLITNY, Michael. Conversation With Xenakis. Perspectives of New Music. Volume 14. No1. Fall-Winter. Seattle: University of Washington, 1975.

\section{DISCOGRAFIA}

Achorripsis, EMI C063- 1001

Analogiques $A$ et B, Philips 835487

Concret PH, Nonesch H- 71245

Diamorphoses, Nonesch H- 71245

Herma, Montaigne Näive, 2004

Metastaseis, Le Chante du Monde, 2001.

Pithoprakta, Le Chante du Monde, 2001.

ST/4, Montaigne Näive, 2004. 